UNIVERSIDADE DE SÃO PAULO

FFCLRP - DEPARTAMENTO DE PSICOLOGIA E EDUCAÇÃO

PROGRAMA DE PÓS-GRADUAÇÃO EM PSICOLOGIA

\title{
Violência doméstica contra a mulher: percepções sobre violência em mulheres agredidas.
}

\section{Thaisa Belloube Borin}

Dissertação apresentada à Faculdade de Filosofia, Ciências e Letras de Ribeirão Preto da USP, como parte das exigências para a obtenção do título de Mestre em Ciências, Área: Psicologia.

\section{RIBEIRÃO PRETO - SP}




\section{UNIVERSIDADE DE SÃO PAULO}

FFCLRP - DEPARTAMENTO DE PSICOLOGIA E EDUCAÇÃO

PROGRAMA DE PÓS-GRADUAÇÃO EM PSICOLOGIA

Violência doméstica contra a mulher: percepções sobre violência em mulheres agredidas.

\section{Thaisa Belloube Borin}

Orientador: Prof. Dr. Antônio dos Santos Andrade

Dissertação apresentada à Faculdade de Filosofia, Ciências e Letras de Ribeirão Preto da USP, como parte das exigências para a obtenção do título de Mestre em Ciências. Área: Psicologia.

\section{RIBEIRÃO PRETO - SP}


FICHA CATALOGRÁFICA

Borin, Thaisa Belloube

Violência doméstica contra a mulher: percepções sobre violência em mulheres agredidas. Ribeirão Preto, 2007.

146 p. : il. ; $30 \mathrm{~cm}$

Dissertação, apresentada à Faculdade de Filosofia, Ciências e Letras de Ribeirão Preto / USP - Dep. de Psicologia e Educação.

Orientador: Andrade, Antônio dos Santos

1. Violência doméstica. 2. Gênero 3. Mulher 


\section{FOLHA DE APROVAÇÃO}

Thaisa Belloube Borin

Violência doméstica contra a mulher:

percepções sobre violência

em mulheres agredidas

Dissertação apresentada à Faculdade de Filosofia, Ciências e Letras de Ribeirão Preto da USP, como parte das exigências para a obtenção do título de

Mestre em Ciências. Área: Psicologia.

Aprovado em:

BANCA EXAMINADORA

Prof. Dr. Antônio Andrade dos Santos

Instituição Universidade de São Paulo - FFCLRP - USP

Assinatura:

Prof. Dr.

Instituição:

Assinatura:

Prof. Dr.

Instituição:

Assinatura: 
A toda minha familia e amigos queridos sempre presentes.

Ao Dr. Borin, modelo de mestre, companheiro e pai incondicional.

À Mommy, pelos cuidados desvelados sempre.

À Vó Lúcia, tia Thereza e tia Rosa pelas mulheres que são $e$ pelo que me ensinam a ser.

À família Danhone pelo acolhimento sincero e amor desmedido. Ao Má por me instigar a paixão pela vida. 


\section{AGRADECIMENTOS}

Aos professores e amigos que tornaram este sonho possível:

Prof. Toninho que me mostrou extrema dedicação pela docência, pelos alunos e acima de tudo pela solidariedade humana.

Prof. Dr. Sérgio Kodato que acolheu meu desejo de trabalhar com violência doméstica.

Prof. Dr. Miguel Bairrão que me abriu as portas da Psicologia Social.

À querida profa. Anamaria Neves que, na paixão pela profissão sempre demonstrada em suas aulas durante a graduação, inspirou-me no exercício da Psicologia, e agora, num feliz reencontro, inspira-me a refletir, na pós-graduação, sobre tema tão sensível que é o da violência doméstica contra a mulher.

À amiga dedicada Rosita que me proporcionou reflexões imprescindíveis ao resultado final deste trabalho.

À incansável Anna que fez esta pesquisa renascer.

À Kamila que me ensinou como é “simples” formatar uma dissertação.

À Dagmar pelos cuidados, pelas esfihas e por, pacientemente, ler minha produção.

Aos funcionários da Delegacia de Defesa da Mulher de Ribeirão Preto que me acolheram com respeito e com a boa vontade de ajudar sempre, em especial, à Daniela Marcussi e à Dra. Marina da Rocha.

À Catalina, Sônia e Regina, responsáveis pelo trabalho do GEAVIDAS acontecer, mulheres de extrema sensibilidade e força.

Às estagiárias do Serviço Social que me faziam companhia durante os atendimentos, por vezes penosos, na Delegacia da Mulher, em especial à Romilda.

Às mulheres que aceitaram participar desta pesquisa, que se abriram sem receio de falar das suas dificuldades, das suas angústias e de seus sonhos.

Às minhas amigas do coração.

À minha família e ao meu amor. 


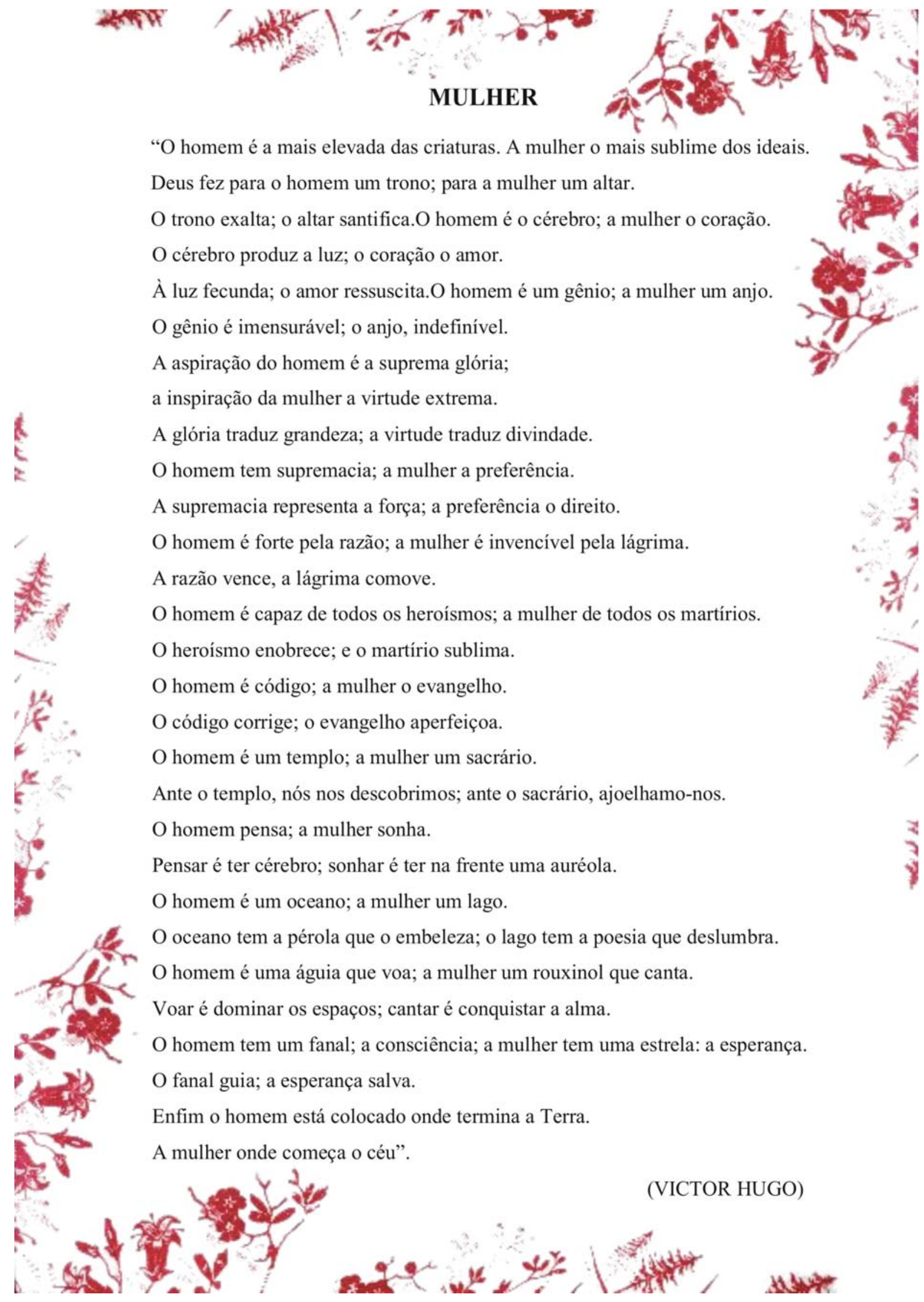




\section{RESUMO}

BORIN, T. B. Violência doméstica contra a mulher: percepções sobre violência em mulheres agredidas. 2007. 146 p. Dissertação (mestrado em Ciências) - Faculdade de Filosofia, Ciências e Letras de Ribeirão Preto, Universidade de São Paulo, Ribeirão Preto, 2007.

A violência doméstica contra a mulher é um fenômeno mundial que não se restringe a determinada raça, classe econômica, idade ou religião. As agressões são divididas em variados tipos como: psicológicas, físicas e sexuais, porém, no relacionamento abusivo, elas acontecem de forma sobreposta. Este estudou objetivou investigar as percepções de violência em mulheres agredidas por seus parceiros, como elas justificam a violência sofrida e quais são os efeitos disso na sua vida. Suas percepções sobre o relacionamento, sobre si mesma, sobre seu parceiro e como isso contribui para que muitas permaneçam nesses relacionamentos abusivos. A pesquisa foi realizada na Delegacia de Defesa da Mulher de Ribeirão Preto, com sete mulheres que denunciaram seus agressores e, assim, foram encaminhadas ao atendimento psicossocial, do Grupo de Estudos e Atenção à Violência Doméstica e Abuso Sexual GEAVIDAS, realizado por psicólogos e assistentes sociais, na própria Delegacia. A investigação foi orientada pela abordagem qualitativa. Foram realizadas observações participantes que resultaram num diário de campo e entrevistas semi-estruturadas, realizadas individualmente, com permissão para serem gravadas e transcritas na íntegra. Os temas investigados nas entrevistas foram sobre a família de origem dessas mulheres, sua família atual (parceiro e filhos), os episódios de agressões sofridas, as expectativas com relação ao Boletim de Ocorrência e à Delegacia de Defesa da Mulher e seus planos futuros. A partir da análise dos resultados foi possível verificar que as mulheres percebem seus parceiros como ingratos e individualistas, que eles não sabem ser companheiros, muitas vezes não são provedores da casa e muito menos "cuidadores" da família, como notamos que seria o esperado de um homem para elas. Isso afeta a auto-estima e a autoconfiança delas, fazendo com que se sintam desamparadas e desanimadas com relação à vida. Elas acreditam que, por terem exercido seu papel de mulher dedicada, disposta a qualquer sacrifício pelos parceiros, mereciam uma maior consideração da parte deles, o que não acontece. Porém, parece haver uma forte idealização das mulheres pelos companheiros que faz com que elas permaneçam com eles à espera de alguma mudança, além de serem dependentes emocionalmente deles e algumas dependentes economicamente também. Concluímos que as lutas contra a violência doméstica e pela libertação das mulheres devem ser acompanhadas por outra luta: a de libertação dos homens, pois ambos sofrem pressões para desempenharem papéis estereotipados pela sociedade, que no caso do homem deve ser o poderoso e no caso da mulher, a frágil e submissa. Com isso, ambos são mutilados na sua individualidade de ser o que realmente desejam. Sendo assim, é necessário que o ser humano aprenda a ser solidário, a respeitar as diferenças do outro e a amar, pois somente assim saberemos conviver em relações de troca e reciprocidade.

Palavras-chave: Violência doméstica. Gênero. Mulher. 


\begin{abstract}
BORIN, T. B. Domestic violence against woman: perceptions about violence in battered women. 2007. 146 p. Dissertação (Master dissertation, Science) - Faculty of Philosophy, Science and Literature of Ribeirão Preto, University of São Paulo, Ribeirão Preto, 2007.

The domestic violence against woman is a world phenomenon that doesn't limit race, economical class, age or religion. The aggressions are divided in varied types as: psychological, physics and sexual, however, in the abusive relationship, they happen in a concomitant way. This research aimed to study the violence perceptions in women battered by your partners. How women justify the suffered violence and which are the effects in their lives. Their perceptions about the relationship, about themselves, about their partner and how it contributes to many of women stay in those abusive relationships. The research was accomplished at the Police Station of Woman's Defense at Ribeirão Preto, with seven women, that denounced their aggressors and, that were taken to a social attendance of a Group of Studies and Attention to Domestic Violence and Sexual Abuse - GEAVIDAS, accomplished by psychologists and social workers, in the own Police Station. The investigation was guided by the qualitative approach. There were accomplished participant observations that resulted in a field diary and semi-structured interviews, applied individually, with permission recording and transcribing them in complete. The themes investigated in the interviews were about their origin's family and current family (partner and children), the episodes of aggressions, their expectations to the Bulletin of Occurrence and the Police Station of Woman's Defense, and their future plans. The results showed us that the women notice your partners as ingrate and individualistic, that they don't know how to be a partner, they don't provide the house and they are not "care-takers" of the family as we noticed that would be expected of a man for them. That affects their self-esteem and their self-confidence, they feel depressed and abandoned. They believe they had done their dedicated woman's role, disposed to any sacrifice for their partners and that they deserve a larger consideration of their part, what doesn't happen. However, there is a strong women's idealization for their partners that make them wait for some change, besides they are emotionally dependent to them and, some of women are dependent economically also. We ended that the fights against the domestic violence and for the women's liberation they should be accompanied by other fight: the men's liberation, because both suffer pressures to play stereotyped roles at society, as in the man's case that he should be the powerful one and in the woman's case, that she should be the fragile and submissive. With that, both are mutilated in their individuality to be what they really want to be. Being like this, it is necessary that the human being learns how to be solidary, to respect the differences of others and how to love, therefore we will only know how to live together with reciprocity.
\end{abstract}

Keywords: Domestic violence. Gender. Woman. 


\section{LISTA DE QUADRO}

Quadro 1 Síntese das classes de categorias, categorias e subcategorias.......................... 97 


\section{LISTA DE TABELA}

Tabela 1 Síntese dos principais aspectos apresentados na entrevista 


\section{LISTA DE ABREVIATURAS E SIGLAS}

BO Boletim de Ocorrência

COJE Centro de Orientação Jurídica

COMVIDA Centro de Convivência de Mulheres Vítimas de Violência

DDM Delegacia de Defesa da Mulher

GEAVIDAS Grupo de Estudos e Atenção à Violência Doméstica e Abuso Sexual

IML Instituto Médico Legal

OEA Organização dos Estados Americanos

ONG Organização Não-Governamental

ONU Organização das Nações Unidas

TCO Termo Circunstanciado de Ocorrência

UNAERP Universidade de Ribeirão Preto

USP Universidade de São Paulo 


\section{SUMÁRIO}

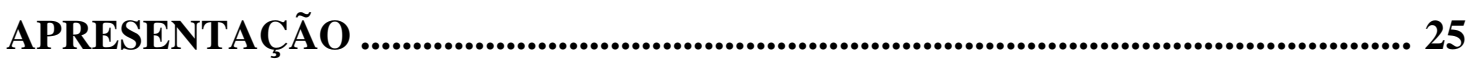

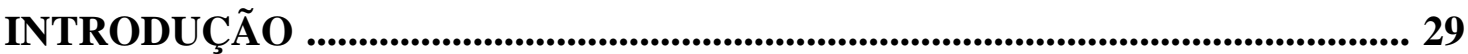

1 RETROSPECTIVA DA HISTÓRIA DA MULHER E DE SUAS CONQUISTAS SOCIAIS .......................................................................................... 29

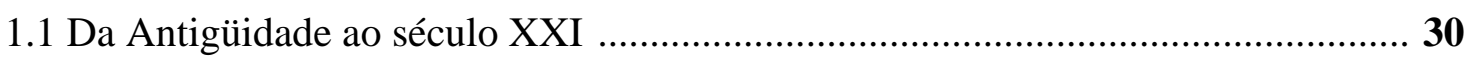

1.2 Brasil Colônia, Império e República .................................................................. 35

1.3 O Movimento Feminista no Brasil e a violência contra a mulher ............................ 39

2 VIOLÊNCIA DOMÉSTICA CONTRA A MULHER ....................................... 45

2.1 Violência doméstica: uma aproximação ............................................................ 45

2.1.1 Violência física .......................................................................................... 48

2.1.2 Violência psicológica ……………………………………………………... 50

2.1.3 Violência sexual ............................................................................................. 53

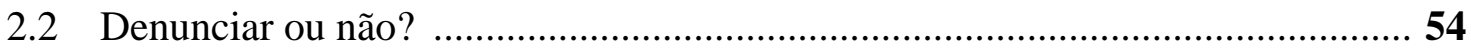

2.3 Dados da violência doméstica contra a mulher e políticas públicas .................... 59

3 GÊNERO: ASPECTOS BIOLÓGICOS OU SOCIAIS ? ...................................... 65

4 OBJETIVOS ....................................................................................................... 71

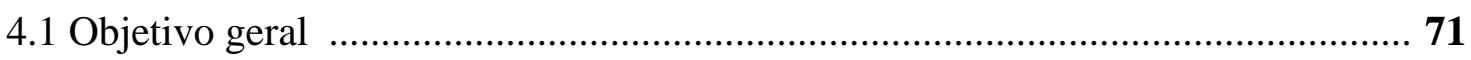

4.2 Objetivos específicos ................................................................................. 71

5 O PERCURSO METODOLÓGICO ................................................................... 73

5.1 Campo de investigação ................................................................................... 73

5.2 Coleta de dados ............................................................................................ 75

5.2.1 Procedimentos da coleta de dados ................................................................... 76

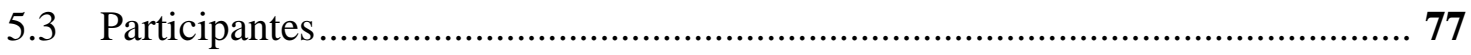

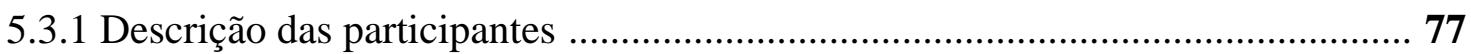

5.4 Procedimentos de análise dos dados ............................................................... 79 


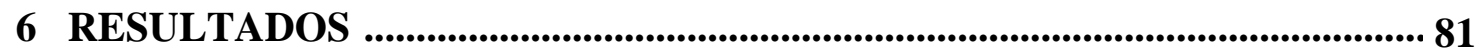

6.1. Fase descritivo-exploratória: o contexto da pesquisa ......................................... 81

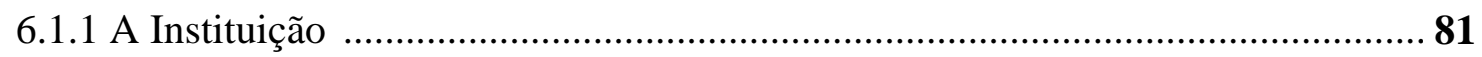

6.1.2 Incursão a campo ………………………………………………………..... 83

6.1.3 Supervisão dos atendimentos e o olhar das estagiárias ...........................................94

6.2 Categorias e marcas discursivas …………………………………………….....97

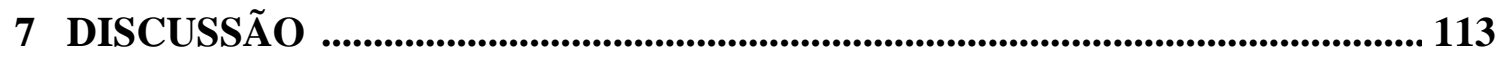

CONSIDERAÇÕES FINAIS E IMPLICAÇÕES SOCIAIS ....................................... 123

REFERÊNCIAS BIBLIOGRÁFICAS .................................................................... 127

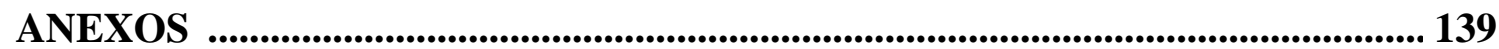




\section{APRESENTAÇÃO}

Compreender o fenômeno da violência doméstica é um desafio que vem sendo realizado por pesquisadores num âmbito internacional (GONDOLF, 1997; BARNETT, 1997; HAMBERGER;1997).Conceituações acerca desse tipo de violência são feitas por diferentes perspectivas de estudos: sociais, antropológicas, econômicas (DAY et al., 2003; MILLER; COHEN, 2003; BUCKLEY, 2000).

A violência permeia o indivíduo desde os seus primórdios, sendo, inclusive, a violência doméstica contra a mulher, ainda legitimada pela sociedade, como se fosse um direito masculino sobre a mulher.

O interesse em pesquisar esse tema nasceu de reflexões da prática institucional da pesquisadora enquanto psicóloga numa Organização Não-Governamental (ONG) destinada ao atendimento de mulheres vítimas de violência doméstica.

Após constatar o sofrimento psíquico das mulheres agredidas por seus parceiros dentro de seu lar, houve o interesse em se pesquisar o tema. Um projeto-piloto foi realizado pela pesquisadora sobre: Representações Sociais do feminino em mulheres vítimas, com as mulheres de um grupo psicoterapêutico que funcionava na ONG citada acima, e em decorrência dos resultados obtidos foi idealizado o projeto da presente pesquisa (BORIN; KODATO, 2004).

Acreditamos que as diferenças de gênero que nos são socialmente impostas propiciam situações para que ocorra a violência doméstica, pois desde os tempos mais remotos existe uma divisão sexual de papéis na sociedade, sendo que aos homens são destinados os papéis de força e poder do espaço público e às mulheres são reservadas as atividades do espaço privado, além dos papéis de obediência e submissão. 
Pretendemos com este estudo propiciar reflexões sobre a mulher vítima de violência doméstica, por meio da investigação dos significados atribuídos por ela sobre violência e de que forma isso contribui para sua permanência no relacionamento com o parceiro agressor.

No caso da presente pesquisa, acreditamos que as percepções sobre violência das mulheres entrevistadas nos possibilitarão um estudo sobre aspectos importantes da violência doméstica contra a mulher, inclusive, sobre os fatores de sua permanência dentro dos lares. Pesquisas apontam que cerca de um terço das mulheres agredidas acolhidas em abrigos retornam para seus parceiros (BARNETT, 2000). As inquietações da pesquisadora apontam para a tentativa de compreender o porquê da permanência da mulher agredida com seu agressor. Por que elas ficam?

Este trabalho inicia-se com um capítulo em que apresentamos um recorte histórico sobre a mulher e suas conquistas sociais com o objetivo de provocarmos reflexões sobre como os contextos político e cultural de cada época influenciam nos papéis desempenhados pelo homem e pela mulher na sociedade. Fazemos ainda uma breve retrospectiva sobre o Movimento Feminista e suas vitórias referentes à cidadania feminina.

O segundo capítulo trata da violência doméstica, seus conceitos e definições para então nos focarmos, especificamente, na violência doméstica contra a mulher, suas diferentes formas de expressão e suas conseqüências físicas e psicológicas. Fizemos, também, nesse capítulo, um pequeno recorte sobre as políticas públicas atuais com o objetivo de levantarmos questões sobre a eficiência do Governo e da própria sociedade na prevenção desse tipo de violência.

O terceiro capítulo evidencia conceituações sobre gênero e a diferenciação dos termos gênero e sexo. Discutimos a questão do poder que é, essencialmente, atribuída ao universo masculino, caracterizando a hierarquia entre os sexos e a sociedade patriarcal e sua relação com a violência doméstica. 
O quarto capítulo define os objetivos gerais e específicos deste estudo.

O quinto capítulo constitui-se do percurso metodológico, dos procedimentos e técnicas utilizadas para a realização desta pesquisa, assim como da descrição do perfil das participantes da pesquisa.

O sexto capítulo compreende a caracterização da Instituição onde a pesquisa foi realizada: a Delegacia de Defesa da Mulher e os resultados obtidos dos discursos por meio da análise de conteúdo (BARDIN, 1997; 1999).

A discussão dos dados define o sétimo capítulo.

O trabalho encerra-se com o oitavo capítulo que traz as considerações finais e as implicações sociais da pesquisa, suas questões e reflexões acerca da mulher, da violência que a atinge e das políticas públicas proporcionadas pelo governo e pela sociedade.

Este estudo apresenta-se como uma possibilidade de repensarmos nossas práticas cotidianas enquanto cidadãos e profissionais da saúde, de repensarmos também os paradigmas de atendimento psicológico institucional, para que possamos aperfeiçoar a assistência psicossocial oferecida à mulher, vítima de violência doméstica, visando à construção de uma sociedade mais democrática e solidária. 


\section{INTRODUÇÃO}

\section{RETROSPECTIVA DA HISTÓRIA DA MULHER E DE SUAS CONQUISTAS SOCIAIS}

Deixa de lado sua rixa com o homem, nem se iguala a eles, nem se submeta,
Nem se humilhe, nem se masculinize
Deixa a história se encarregar dessa querela
Qual é o seu papel aqui e agora?
Não está na hora de acordar e tomar o seu lugar?
Desfaça-te da dor, dos temores, rancores e massacres
E seja sempre e somente uma mulher

(ENI CORRALEF DE ANDRADE apud PATTI, 2004)

Este capítulo evidencia os papéis desempenhados pelo homem e pela mulher de acordo com o contexto de cada época e sociedade. Além de ressaltar a evolução da conquistas sociais femininas e como elas influenciaram no exercício da cidadania da mulher e na sua conquista da esfera pública, principalmente, no Brasil.

A história da mulher possui vértices de submissão e dominação pelo homem. Nos primeiros anos de sua vida, a mulher era dominada pelo pai e depois do casamento pelo marido. O homem sempre foi tido como ser superior e cabia a ele, portanto, exercer a autoridade; assim o fundamento escolhido para justificar a repressão da mulher era a superioridade masculina (MURARO, 1975).

Foram impostos à mulher, ao longo da história, modelos que conservavam intacta sua subordinação ao homem e estereótipos como sensível, delicada, amorosa, altruísta, que culminavam em deveres maternos levando-a a um confinamento doméstico, isto é, sua participação como membro da sociedade ficou restrita à esfera privada.

A construção social de estereótipos e papéis a serem desempenhados pela mulher diversificava-se de acordo com a expectativa dos grupos sociais de épocas distintas, ou seja, o 
que uma mulher deveria realizar em sua vida era relativo à cultura daquela determinada época.

A seguir, trataremos desses papéis definidos pela sociedade à mulher, em vários momentos da história e culturas diferentes, mostrando o seu desenvolvimento e suas conquistas sociais.

\subsection{Da Antigüidade ao século XXI}

As principais organizações da Antigüidade no que se refere à política e cultura são Egito, Grécia e Roma. Homens e mulheres possuíam suas respectivas funções sociais com responsabilidades diferenciadas assim como ainda acontece nos dias atuais.

No Egito, a mulher desempenhava papel de igualdade em relação ao homem e tinha mais liberdade que as demais mulheres de outras sociedades de sua época (NOBLECOURT, 1994). Essa igualdade entre os sexos, no Egito, era um aspecto socionatural, isto é, não havia relação de inferioridade da mulher em relação ao homem, pois a mulher egípcia não sofria nenhum tipo de tutela. O poder do pai era tido como uma proteção e não como dominação. A escolha do futuro marido não dependia da aprovação do pai. O casamento era considerado um ideal social cujo desenvolvimento harmonioso dependia exclusivamente dos noivos (SANTOS, 2006). “Dessa forma, homens e mulheres assumiam seus compromissos frente à sociedade, devendo cumprir os deveres inerentes a sua escolha” (SANTOS, 2006).

Na Grécia Antiga, a mulher era considerada inferior, marginalizada e perigosa. Isso era representado através dos mitos, como o de Pandora que revelava a mulher como responsável por espalhar todos os males do mundo (PATTI, 2004). As mulheres gregas tinham como funções tanto a maternidade quanto os deveres do matrimônio, assim, a vida das gregas estava inteiramente definida pelos papéis de esposa e mãe. Em razão disso, as 
mulheres viviam confinadas a maior parte do tempo em casa e só saíam para fazer compras acompanhadas por uma escrava, por ocasião das festas das cidade ou por certos acontecimentos familiares (ZAIDMAN, 1990).

Aos homens gregos cabiam as atividades mais nobres, como filosofia, política e artes. A mulher era excluída desse mundo do pensamento e do conhecimento, tão valorizado pela civilização grega, tendo, assim, seu horizonte limitado, pois a ela ficava restrito o trabalho pesado enquanto o homem era responsável pelo trabalho intelectual (ARANHA, 1989).

Em Roma, a vida da mulher era semelhante ao da mulher grega, ou seja, sua vida se limitava a casa (PATTI, 2004; MACEDO, 1990). Conforme citado por Patti (2004, p. 23), “alguns historiadores descrevem que a família romana estava submetida a um patriarcado com valores morais e civis rígidos. Assim, a mulher ficou submetida a estes valores, mesmo as que tinham melhores condições sócio-econômicas”.

A partir do século XII, as épocas da Idade Média, do Renascimento e da Revolução Industrial trouxeram profundas modificações referentes ao papel desempenhado pela mulher, desde perseguições e extermínios à figura feminina até a sua inclusão no mercado de trabalho, ocupando lugares, antes, estritamente masculinos.

A Idade Média, de acordo com Machado (2007), continuou sendo uma sociedade acentuadamente marcada pela hegemonia masculina, onde as manifestações culturais possuíam o registro das lutas pelo poder e dos preconceitos masculinos.

O casamento, nesse período, foi institucionalizado pela Igreja que valorizava a maternidade e o papel de boa mãe;

a relação entre marido e mulher não podia doravante ser de amizade e pressupor a igualdade de direitos: [...] Um bom casamento era a comunhão entre o homem e a mulher mas, segundo os ensinamentos morais da Igreja, ele só era realmente bom quando o homem "governava" e a mulher obedecia incondicionalmente (OPITZ apud MACHADO, 2007).

Foi também na Idade Média que começou a caça às bruxas, sendo um dos motivos 
certos tipos de conhecimentos utilizados pelas mulheres de origem camponesa, como práticas e crenças que delineavam modos de tratar doenças e lidar com as situações-limite da existência (nascimento, acasalamento, morte), faziam com que fossem tidas como criminosas dentro do contexto histórico da Contra Reforma (ZORDAN, 2005).

Assim, as mulheres sofreram uma intensa perseguição, nas quais muitas eram tidas como bruxas, além de serem responsabilizadas por tudo que não desse certo na sociedade como más colheitas, epidemias e mortes inexplicáveis (MACHADO, 2007).

No século XV, mais precisamente em 1484, dois inquisidores alemães pertencentes à Ordem dos Dominicanos escreveram um dos primeiros manuais de caça às bruxas, chamado “Malleus Maleficarum”, traduzido em português com o título de “O Martelo das feiticeiras” (PATTI, 2004; ZORDAN, 2005). Conforme Patti (2004), esses inquisidores associaram a transgressão sexual da mulher à transgressão da fé que também era considerada política e, assim, as mulheres eram punidas por serem vistas como indutoras ao pecado. Muraro (1993) faz um resumo das teses apresentadas no referido manual que permitiram o massacre feminino baseado nos seguintes tópicos:

1) O demônio, com a permissão de Deus, procurou fazer o máximo de mal aos homens a fim de se apropriar do maior número possível de almas;

2) O domínio do demônio vem através do controle e da manipulação dos atos sexuais. Pela sexualidade, o demônio pode apropriar-se do corpo e da alma dos homens. Foi pela sexualidade que o primeiro homem pecou e, portanto, a sexualidade é o ponto mais vulnerável de todos os homens;

3) Como as mulheres estavam essencialmente ligadas à sexualidade, elas se tornaram os agentes por excelência do demônio (as feiticeiras). Essas mulheres tinham mais convivência com o demônio porque Eva nasceu de uma costela torta de Adão; 
4) Houve uma falha na formação da primeira mulher, por ter sido criada a partir de uma costela recurva, ou seja, uma costela do peito, cuja curvatura é, por assim dizer, contrária à retidão do homem. Em virtude dessa falha, a mulher era animal imperfeito;

5) A primeira e maior característica, aquela que dava todo poder às feiticeiras, era copular com o demônio. Satã era, portanto, o senhor do prazer;

6) Uma vez obtida a intimidade com o demônio, as feiticeiras eram capazes de desencadear todos os males, especialmente a impotência masculina, a impossibilidade de se livrar de paixões desordenadas, abortos, oferendas de crianças a Satanás, estrago das colheitas, doenças dos animais, entre outras;

7) Esses aspectos eram mais hediondos do que os próprios pecados de Lúcifer quando da rebelião dos anjos e dos primeiros pais por ocasião da queda, porque agora as bruxas pecavam com Deus e o Redentor (Cristo) e, portanto, esse crime era imperdoável e por isso só podia ser resgatado com a tortura e a morte.

Muitas mulheres foram torturadas e queimadas vivas até a morte sem terem cometido crime algum. A Inquisição marcou uma época sangrenta para as mulheres de intensa perseguição e crueldade (PATTI, 2004).

O período do Renascimento trouxe consigo novas regras de conduta para as mulheres que, finalmente, deixaram de ficar restritas à esfera doméstica para terem alguma atuação social, começando a freqüentar salões, movimentos políticos e literários da época (SAGIM, 2004). Nessa época, os casamentos eram decididos através de acordos entre os pais dos noivos que combinavam o valor dos dotes que deveriam ser oferecidos ao futuro marido, medindo-se, assim, o valor da mulher pelo dote em questão. Após o matrimônio, as funções femininas eram limitadas à procriação para conservação o patrimônio da família, pois se acreditava que, quanto mais filhos tivessem, mais braços haveria para o cultivo da terra e, assim, a família numerosa era considerada abençoada por Deus. Porém, se essa finalidade não 
se cumprisse, a mulher era, geralmente, devolvida para a família ou internada num convento (MURARO, 1975).

Foi a partir do século XVIII, apesar de tamanha repressão, que a história começou a registrar nomes de mulheres que lutaram pela libertação feminina (SAPORETI, 1985):

- Mary Wollstonecraff (1759-1797), inglesa, que em 1790 escreveu a "Defesa dos Direitos da Mulher”, obra que alcançou muita repercussão na época;

- Abigail Smith Adams (1744 - 1818), norte-americana, escreveu ao marido John Adams, que estava se reunindo na Filadélfia com outros colegas para a elaboração da Declaração de Independência Americana, pedindo que a mulher fosse lembrada no novo Código de Leis;

- Elizabeth Cady Stanton (1815 - 1902), norte-americana, líder de um movimento social, colaborou com a criação, em 1860, da Associação das Mulheres Trabalhadoras.

No século XIX, marcado ainda pelo princípio da hegemonia masculina, nasceu o Movimento Feminista que determinou importantes mudanças estruturais na vida das mulheres. A Revolução Industrial promoveu algumas mudanças nos papéis assumidos pelas mulheres na sociedade. Elas reivindicavam a melhoria das condições de vida e de trabalho, sua participação na política e a igualdade de direitos entre os sexos, porém continuavam devendo obediência ao homem (MACHADO, 2007). Conforme a autora, as mulheres começaram, realmente, a lutar pelos seus direitos no início do século XX, exigindo por melhores ambientes de trabalho, salários dignos e acesso aos cursos superiores.

Um momento marcante do início do século XX para a história da mulher foi quando 150 operárias americanas foram queimadas vivas no interior de uma fábrica em Nova York, trancadas por seus patrões, por estarem fazendo manifestações de greve, no dia 8 de março de 1908. Esse dia ficou consagrado como o Dia Internacional da Mulher que é comemorado até os dias atuais (AZEVEDO, 1985). 
Segundo Verucci (1985), as grandes mudanças do século XX referentes ao papel da mulher só começaram a ocorrer após a Segunda Guerra Mundial. Trataremos, mais adiante, com detalhes, as mudanças realizadas na cultura brasileira e, por conseqüência, nos papéis desempenhados pelas nossas mulheres.

E, finalmente, no século XXI,

os antigos estereótipos começam - lentamente - a desfazer-se. A mulher está ingressando no setor público e, de forma incipiente, partilhando o setor privado com o homem: envolvendo-o nos trabalhos da casa e na criação dos filhos, esboçando-se, assim, uma maior integração homem-mulher (MACHADO, 2007).

\subsection{Brasil Colônia, Império e República.}

No Brasil, a divisão dos papéis sociais desempenhados por homens e mulheres não aconteceu de forma diferente do relatado anteriormente nas diversas culturas e épocas citadas.

Os povos que, inicialmente, habitavam o Brasil eram os índios. Entre eles já havia uma divisão sexual do trabalho, tanto no campo, como dentro de casa. As mulheres eram destinadas as tarefas domésticas como a fabricação de redes de fio de algodão, farinha de mandioca, vasilha de barro e aos homens cabiam as tarefas de fabricação de arcos e flechas, instrumentos de música e construção de oca e canoas (FERREIRA; CUSTÓDIO, 2000).

As índias foram as primeiras mulheres encontradas pelos homens brancos na América, e a nudez delas os incitavam à lascívia e a luxúria (RAMINELLI, 2000). Os homens usavamnas para suas aventuras sexuais, sendo dessa união entre os europeus com as índias que se fundou e se desenvolveu a sociedade colonial entre os séculos XVI e XVII (FERREIRA; CUSTÓDIO, 2000).

Para o crescimento da colônia era preciso desenvolver atividades econômicas que dessem lucros, então, trocou-se o pau-brasil pela cana-de-açúcar e a mão-de-obra do nativo brasileiro foi gradativamente desestimulada pela metrópole e substituída pela escravidão 
negra. As funções da escrava eram de produzir bens e prestar serviços e, além disso, ela era obrigada a desempenhar um papel de cunho sexual, pois ela era o instrumento de prazer de seu senhor e reprodutora da mão-de-obra escrava. Já o papel da mulher branca nessa época era a procriação de descendestes brancos e puros para dar continuidade ao seu nome e a família (FERREIRA; CUSTÓDIO, 2000).

De acordo com Silva (1992, p. 64-65),

[...] o senhor branco era a figura centralizadora do poder. Neste contexto a mulher branca rica era auxiliadora do esposo na manutenção da sua posição social, desempenhando funções ligadas à procriação e supervisão das tarefas domésticas realizadas por escravas e escravos [...].

Nessa época escravocrata, as mulheres brancas eram educadas em ambiente rigorosamente patriarcal, elas escapavam do domínio do pai para, com o casamento, serem dominadas pelo marido, caracterizando uma posição submissa perante a figura masculina, tanto dentro da família como na sociedade. A única possibilidade de fugir disso era a reclusão em um convento (MURARO, 1975).

A educação não era valorizada nessa época. As mulheres das classes sociais altas tinham pouco acesso à escassa cultura existente na colônia. A elas era permitido saber ler apenas uma carta ou escrever uma receita culinária, e para isso era necessário apenas um mínimo de educação formal que se realizava em casa ou em conventos (ARAÚJO, 2000).

A chegada da Família Real e de toda a Corte Portuguesa no Rio de Janeiro, no final de 1807, trouxe algumas influências que acabaram por mudar a situação reinante na colônia, embora muitos costumes em relação às mulheres tivessem sido mantidos. Surgiram, nessa época, algumas poucas oportunidades de instrução laica para a mulher. As senhoras portuguesas, francesas, e algumas alemãs foram as responsáveis por ampliar um pouco o acanhado horizonte intelectual da mulher brasileira, pois elas lhes ensinavam costura, bordado, religião, rudimentos de aritmética e de línguas (PATTI, 2004). 
O surgimento da burguesia instalou no país uma nova mentalidade que reorganizou as vivências familiares e domésticas, o tempo e as atividades femininas, como também a sensibilidade e a forma de se pensar o amor. A mulher de elite passou a marcar presença em cafés, bailes, teatros e em outros acontecimentos da vida social (D’INCAO, 2000). Porém, as mulheres continuavam exercendo os papéis de esposas modelares e boas mães o que reforçava, cada vez mais, a idéia de que ser mulher era ser integralmente mãe dedicada e atenciosa (BASSANEZI, 2000; D’INCAO, 2000).

No século XX, com a crescente industrialização do país, as mulheres passaram a adentrar no mercado de trabalho ocupando profissões como: operárias, enfermeiras, secretárias e professoras (D’INCAO, 2000).

Porém, de acordo com Machado (2007),

o trabalho da mulher não era visto como realização profissional ou emancipação econômica da mesma, mas apenas como um complemento financeiro à renda familiar. Por outro lado, a participação da mulher no mercado de trabalho não diminuiu a carga de obrigações que ela suportava em casa, no cuidado da família.

Uma das modificações que ocorreram no fim da Segunda Guerra Mundial, com a ascensão da classe média, foi a nova condição de vida nas cidades que diminuiu a distância entre os homens e as mulheres (modificando, inclusive, as práticas sociais do namoro e a intimidade familiar). Porém, as distinções entre os papéis femininos e masculinos, entretanto, continuavam nítidas: o homem mantinha a autoridade e era responsável pelo sustento da família, e a mulher continuava com as ocupações domésticas e mantinha as características da feminilidade como: o instinto materno, a pureza, a resignação e a doçura; a moral sexual diferenciada permanecia forte e o trabalho da mulher, ainda que cada vez mais comum, era cercado de preconceito e visto como subsidiário ao do homem (BASSANEZI, 2000).

Em meados dos anos 1950, o casamento, porta de entrada para a realização feminina, era tido como “o objetivo” de vida de todas as jovens solteiras. Elas aprendiam que havia 
diferença sexual entre homens e mulheres e que a felicidade conjugal dependia, fundamentalmente, dos esforços femininos para manter a família unida e o marido satisfeito. Assim, ser mãe, esposa e dona-de-casa era considerado o destino natural das mulheres. Portanto, maternidade, casamento e dedicação ao lar faziam parte da essência feminina, sem possibilidade de contestação. As vocações para a maternidade e a vida doméstica seriam marcas da feminilidade, enquanto a iniciativa, a participação no mercado de trabalho, a força e o espírito de aventura definiriam a masculinidade (BASSANEZI, 2000).

Nessa época, a moral sexual dominante exigia virtude das mulheres solteiras, muitas vezes confundida com ignorância sexual e, sempre, relacionada à contenção sexual e virgindade. Em contrapartida, as relações sexuais dos homens com várias mulheres não só eram permitidas como freqüentemente incentivadas. A virilidade deles era medida em grande parte por essas experiências, sendo comum serem estimulados a começar cedo sua vida sexual (BASSANEZI, 2000).

Ocorreu, nessa mesma década de 1950, o crescimento da participação feminina no mercado de trabalho, especialmente no setor de serviços em escritórios, no comércio ou em serviços públicos. Surgiram, então, mais oportunidades de empregos em profissões como: enfermeira, professora, funcionária burocrática, médica, assistente social e vendedora. Essa tendência demandou uma maior escolaridade feminina, tanto que, no ensino elementar e no médio, o número de mulheres já estava próximo ao dos homens, o que provocou, sem dúvida, mudanças no status social das mulheres. Porém, eram nítidos os preconceitos que cercavam o trabalho feminino nessa época (BASSANEZI, 2000).

Na década de 1960, apesar da existência de uma maior participação feminina nas questões econômicas e sociais, a mulher ainda tinha como modelo a crença de que ela deveria esquecer-se de si mesma para melhor amar e cuidar dos que a circundava e que seria a culpada pelos problemas que ocorressem aos filhos e à família em geral. A responsabilidade 
da mulher com a casa, o marido e a educação dos filhos foi, por muito tempo, por ela internalizada a ponto de, por muitas décadas, a sua dedicação ser, exclusivamente, voltada ao espaço privado do lar (MACHADO, 2007).

Mas a partir da década de 1970, a competência profissional feminina passou a ser responsável pelo status adquirido na sociedade, a profissão que se exercia era mais importante do que a família a que se pertencia. Em razão da liberação sexual, apoiada pelo movimento hippie, ocorreu uma desvalorização da virgindade o que teve como conseqüência o aumento da quantidade de filhos ilegítimos. O adultério passou a ser caso de divórcio e não de morte, direito adquirido somente nessa década e a noção de casamento começou a ser ressignificada pelos indivíduos (MURARO, 1975).

Nas décadas de 1980 e 1990, ocorreu um ingresso maciço de mulheres no mercado de trabalho em razão das mudanças econômicas e sociais ocorridas nesse período e, principalmente, pela emancipação feminina ocorrida na década de 1970 (BRASIL, 2007).

No século XXI, segundo Machado (2007), as mulheres exercem todos os tipos de atividades não havendo, como no passado, um espaço dito masculino que não possa ser ocupado por mulheres, fortalecendo, assim, sua liberdade de pensamento e ação, o que representa a conquista de uma grande luta liderada pelo Movimento Feminista.

\subsection{O Movimento Feminista no Brasil e a violência contra a mulher}

O Movimento Feminista surgiu no século XIX, na época da Revolução Francesa, como uma forma de reconhecer e superar as relações assimétricas entre os gêneros, na luta pela igualdade entre os sexos, liberdade de expressão, de pensamento e direito à cidadania feminina (SAGIM, 2004).

Segundo Alves e Pitanguy (1981 apud PEDRO, 2002, p.26), 
o feminismo busca repensar e recriar a identidade de sexo sob uma ótica em que o indivíduo, seja ele homem ou mulher, não tenha que adaptar-se a modelos hierarquizados, e onde as qualidades "femininas" ou "masculinas" sejam atributos do ser humano em sua globalidade.

Esse movimento buscou “dar às mulheres um lugar na história, de preferência escrito por elas mesmas, tirando-as do anonimato e invisibilidade” (SAGIM, 2004, p. 11) e acabou influenciando o pensamento de algumas mulheres do mundo, inclusive no Brasil.

O Movimento Feminista surgiu no Brasil em meados do século XIX, por volta de 1850, quando um pequeno grupo de manifestantes declarou insatisfação com os papéis tradicionais atribuídos pelos homens às mulheres, idealizando o fim da dominação masculina e da estrutura patriarcal.

Porém, o feminismo tornou-se visível, no Brasil, apenas no início do século XX quando iniciou sua luta pelo direito ao voto feminino. Em 1910, as mulheres iniciaram sua luta e a vitória aconteceu somente em 1932. A aceitação do voto feminino foi uma grande conquista do direito eleitoral e representou um avanço nas lutas feministas, mesmo sabendose que nesse período o voto era facultativo, ou seja, votava aquela que se interessava pela política e pelos negócios públicos (SAPORETI,1985).

Após adquirirem o direito ao voto, as mulheres obtiveram outras conquistas, como: ingressar nas instituições escolares e participar do mercado de trabalho sem a necessidade da autorização do marido. Adquiriram também direitos como: licença-maternidade de quatro meses, creches, obtenção da guarda do filho em caso de separação, aposentadoria integral com trinta anos de serviço, entre outros (SILVA, 1992; PINTO, 2003).

A luta continuou para que outras metas fossem alcançadas, principalmente, com relação à violência doméstica, pois, as mulheres perceberam que denunciar, tornar pública as violências de que eram vítimas não era vergonha, mas ao contrário, era lutar pela sua dignidade (VERARDO, 2007b). 
Assim, em 1960, o Movimento Feminista rompeu o silêncio e passou a denunciar o espancamento das mulheres (AZEVEDO, 1985; HEISE, PITANGUY, GERMAIN, 1994; SAFFIOTI, ALMEIDA, 1995; STARK; FLITCRAFT, 1996) que começava a ser percebido como um problema social tanto pelas proporções quantitativas quanto pela gravidade de suas conseqüências (AZEVEDO, 1985).

Com isso,

a opinião pública foi sendo sensibilizada para a questão, que vinha sendo tratada apenas sob a ótica das relações interpessoais. Assim, um fenômeno que era considerado como um componente natural decorrente das relações pessoais e que, desta forma, era remetido à dinâmica do mundo doméstico - o domínio do privado - passa a ser publicizado, assumindo uma conotação política (SILVA, 1992, p. 97-98).

O Movimento Feminista brasileiro foi responsável por tornar pública a violência contra a mulher, principalmente a violência sexual e a doméstica. Tal mobilização se deu em função da brutalidade da violência conjugal e da impunidade dos agressores (D’OLIVEIRA apud SOUZA, ADESSE, 2004), assim, as mulheres reclamavam por medidas e soluções, uma vez que o crime passional não era punido (AZEVEDO, 1985).

As feministas reivindicavam abrigo, assistência jurídica especial à população feminina e atendimento policial, pois acreditavam que o Estado é quem deveria promover as políticas públicas e a assistência aos cidadãos (PAVEZ, 1997). Com isso, o movimento de mulheres iniciou parcerias com o Estado no sentido da implementação de políticas públicas na tentativa de prevenir a violência contra a mulher (SCHRAIBER, D’OLIVEIRA, 2007).

No início de 1980, surgiu o SOS-Mulher ${ }^{1}$, uma entidade autônoma que era voltada ao atendimento jurídico, social e psicológico de mulheres vítimas de violência. Esse serviço era mantido voluntariamente pelas feministas que apesar das dificuldades e precariedades

\footnotetext{
${ }^{1}$ O SOS-Mulher foi o primeiro grupo de combate à violência contra a mulher, criado em 10 de outubro de 1980 (BETTO, 2007). O primeiro foi em São Paulo, logo em seguida em Campinas e no Rio de Janeiro (DINIZ, 2007).
} 
institucionais (VERARDO apud SOUZA, ADESSE, 2004), “tiveram seu objetivo cumprido: a violência contra a mulher, na sua forma mais conhecida, a violência conjugal, era agora uma questão pública” (SCHRAIBER, D’OLIVEIRA, 2007). Além de atender a mulher, o SOSMulher realizava grupos de reflexões e debates junto à opinião pública sobre a questão da violência (TELES, 1993).

Devido às reivindicações do movimento feminista, foi criada em 1985, inicialmente em São Paulo, a Delegacia de Defesa da Mulher $^{2}$ (DDM) (SILVA, 1992). Assim, a década de 1980 foi marcada pela possibilidade de a mulher recorrer a uma delegacia para denunciar a violência sofrida em casa (PINHEIRO, 2000). Considerada como desvio da normatividade social, e não mais uma norma aceita socialmente, a violência doméstica começa a ser interpretada como um crime e, como tal, enquadra-se na lei, sendo passível de responsabilização e punição (SCHRAIBER, D’OLIVEIRA, 2007).

Conforme Grossi (apud MAZONI, 2007), com a transição das entidades SOS-Mulher para as Delegacias de Defesa da Mulher altera-se o caráter dos atendimentos, de militante para profissional. Com isso, o primeiro passo, a partir do momento da criação da DDM, foi o de colocar profissionais especializados no atendimento direto às mulheres em situação de violência (MAZONI, 2007).

Em 1986, foi criado o Centro de Orientação Jurídica (COJE) para orientar juridicamente a mulher, informá-la sobre seus direitos e encaminhá-la ao local competente para tomar a medida legal, além de dar assistência psicológica. E, posteriormente, foi criado o Centro de Convivência de Mulheres Vítimas de Violência Doméstica (COMVIDA), primeiro abrigo do país com a função de abrigar as mulheres, em situação de risco de vida, em local sigiloso (PAVEZ, 1997).

\footnotetext{
${ }^{2}$ O Brasil foi o primeiro país no mundo a criar a Delegacia de Defesa da Mulher (SCHRAIBER, D’OLIVEIRA, 2007).
} 
Desta forma, o SOS-Mulher, a DDM, o COJE e o COMVIDA foram espaços diferenciados conquistados pelas mulheres para se lidar com a questão da violência sofrida por elas, que antes era tratada no âmbito do privado-doméstico (MAZONI, 2007).

Além dos abrigos e serviços de atendimento às mulheres, vítimas de violência, a luta passou a ter como objetivo, alterações na legislação, visando ao término da impunidade, para que as mulheres pudessem ter proteção após a denúncia e os agressores serem presos. As mulheres, vítimas de violência doméstica, teriam garantias legais do direito de continuarem em suas casas e acesso a programas que as ajudassem no seu sustento e no de seus filhos (8 DE MARÇO ..., 2007).

No entanto, havia muitas dificuldades ao se tentar aplicar uma lei contra a violência na esfera das relações conjugais e familiares (SCHRAIBER, D’OLIVEIRA, 2007). Por isso, agressões cometidas por pessoas próximas das mulheres vítimas, principalmente, por seus parceiros precisavam de uma lei específica. Assim, em 7 de agosto de 2006, foi sancionada pelo Presidente da República Luiz Inácio Lula da Silva, uma lei que visa a proteger as vítimas da violência doméstica, chamada Lei Maria da Penha³

A lei trouxe algumas vantagens, em que "suas medidas correspondem às necessidades reais para garantir a integridade física, psicológica e patrimonial da vítima e de seus dependentes” (ALVES, 2006). Mas essa lei não trouxe soluções ao grande problema social, pois, de acordo com Cabette (2006), a lei não previne e não repreende a violência doméstica. Para o autor, a lei não resolverá o problema da violência, pois ela está diretamente relacionada com o modelo de sociedade ao qual estamos inseridos.

\footnotetext{
${ }^{3}$ Em 29 de maio de 1983, a biofarmacêutica Maria da Penha Maia foi vítima de violência praticada pelo seu exmarido, que disparou contra ela durante o sono, deixando-a paraplégica. Após a saída do hospital, sofreu o segundo atentado em que o marido tentou eletrocutá-la enquanto tomava banho. Transcorreram dezenove anos e seis meses entre a violência e a prisão do criminoso (ALVES, 2006). Esse caso chegou à Comissão Interamericana dos Direitos Humanos da Organização dos Estados Americanos (OEA), que acatou, pela primeira vez, a denúncia de um crime de violência doméstica. Em razão disso, surgiu uma lei contra a violência doméstica como forma de prevenir, punir e erradicar a violência doméstica (CONFEDERAÇÃO ..., 2007).
} 
O problema está na medida em que, a lei ao ser editada, deve obedecer a todos os princípios constitucionais vigentes, e a Lei Maria da Penha acabou por não mudar na prática o que ocorria antes da sua promulgação. Ao oferecer representação contra seu agressor, a vítima continua à mercê do mesmo, tendo em vista que no momento em que a mulher prestar queixa de agressão será lavrado um Boletim de Ocorrência, para posteriormente dar início ao Inquérito Policial, sem prisão imediata do agressor. Portanto, a intenção da nova lei, de encarcerar imediatamente o agressor e tirá-lo do convívio de sua família, evitando assim novas agressões, não atingiu seu objetivo. Na realidade, ao representar contra seu parceiro, a mulher não tem a garantia proposta pela lei, de que não sofrerá mais agressões por parte deste, pois, o que acontece na maioria das vezes, que é a ocorrência de uma nova agressão em face da denúncia realizada pela mulher na DDM. ${ }^{4}$

\footnotetext{
${ }^{4}$ Informações, gentilmente, cedidas por um advogado da área penal e professor universitário.
} 


\section{VIOLÊNCIA DOMÉSTICA CONTRA A MULHER}

"Homens são ensinados a se desculparem pela sua fraqueza, e as mulheres, pela sua força.”

(LOIS WYSE apud BARNETT, 2000)

O enigma das relações abusivas e o porquê as mulheres permanecem nelas começa com a longa jornada do aprendizado do que é ser mulher na nossa cultura, que ocorre com o processo de socialização ${ }^{5}$. A sociedade expõe homens e mulheres, garotas e garotos a diferentes expectativas como forma de aprendizado de sua identidade de gênero. A cultura permite e encoraja a agressão masculina, mas a monitora (BARNETT, 2000).

A construção social da posição submissa da mulher feminina fez com que o homem desfrutasse de uma posição de poder em relação à mesma, exacerbando, com isso, a violência de gênero. Nesse sentido trataremos neste capítulo o que caracteriza a violência doméstica. Contudo, vamos fazê-lo sob o recorte da violência doméstica contra a mulher que tem como agressor o seu parceiro, descreveremos os tipos de agressões sofridas por elas, o porquê da mulher, geralmente, não denunciar esse agressor, como o governo lida com essa questão social e quais políticas de prevenção à violência ele promove para solucionar ou amenizar esse problema.

\subsection{Violência doméstica: uma aproximação}

Azevedo e Guerra (2000) e Chauí (1984) afirmam que violência é a imposição da força e a considera sob dois ângulos: a violência com a finalidade de dominação/exploração, superior/inferior, ou seja, como resultado de uma assimetria na relação hierárquica e o tratamento do ser humano não como sujeito, mas como coisa, caracterizado pela inércia, pela passividade e pelo silêncio, quando a fala e atividade de outrem são anuladas. "Assim, tanto

\footnotetext{
${ }^{5}$ Socialização é um processo em que o indivíduo aprende a ser um membro da sociedade (BARNETT, 2000).
} 
num caso quanto no outro, estamos diante de uma relação de poder, caracterizada num pólo pela dominação e no outro pela coisificação” (AZEVEDO, GUERRA, 2000, p. 46).

Tanto para Arendt (1973) quanto para Azevedo (1985), Saffioti (1998), Romanelli (1997), Azevedo e Guerra (2000), Johnson e Ferraro (2001), a violência é uma questão de poder que está legitimada pela cultura, em que o mais forte se sente no direito de subjugar o mais fraco, como se fosse uma justiça natural. Para Barnett (2000), o poder não está na natureza humana, mas em um comportamento apreendido e incorporado por várias gerações que funciona como ação disciplinar.

Acreditamos que a violência é um fenômeno constante no universo das relações e entre as suas formas mais perversas, encontramos a violência doméstica.

De acordo com Day et al. (2003) e a Organização das Nações Unidas (ONU) (apud IPAS, 2007a), violência doméstica é qualquer ato que resulte em sofrimento, danos físicos, sexuais e psicológicos, inclusive coerção e privação da liberdade.

Segundo Amaral (2002 apud MARINHEIRO, 2003), esse tipo de violência ocorre mais freqüentemente no espaço privado do que no espaço público porque é no lar que quase sempre não é presenciada por ninguém. Para Heise, Ellsberg e Gottemoeller (1999), ocorre no ambiente privado por ser o local em que a mulher apresenta maior vulnerabilidade, principalmente, a agressão que é cometida pelos parceiros. Já para Pavez (1997), ocorre no lar “pela legitimidade social que lhe é atribuída”.

A violência doméstica é uma das formas mais comuns de manifestação de violência e, no entanto, uma das mais invisíveis, geralmente, fica restrita ao lar e aos seus moradores que, por muitas vezes, banalizam e naturalizam o fenômeno. Tavares (2002), Habermas (1980) e Bourdieu (1995) afirmam que a violência é estrutural pelo fato da nossa sociedade ser marcada por profundas desigualdades na distribuição de riqueza social. 
Para Roque e Ferriari (2002), “a pobreza em si não explica a violência, sendo certo, no entanto, que o pauperismo crescente da população [...] segrega e coloca à margem um número sempre maior de pessoas, [...] numa economia desempregadora, seletiva e excludente [...]”.

Marinheiro (2003) afirma que a violência ocorre em todas as classes sociais, mas é mais visível naquela em que há desestruturação familiar, miséria e pobreza, fatores que favorecem os comportamentos agressivos. Conforme Heise, Ellsberg e Gottemoeller (1999), as mulheres que vivem na pobreza têm maior probabilidade de serem vítimas de violência do que as mulheres de condição econômica mais elevada.

Para Furniss (1993) e Gabel (1997), a violência doméstica costuma ser equivocadamente associada à pobreza. Buckley (2000, p. 2) afirma que “esse tipo de violência é uma praga que se espalha pelo mundo, sem circunstâncias definidas, sem distinção de classe econômica, idade e raça”. Para o autor, a realidade nos mostra que países ricos e famílias mais privilegiadas socioeconômicas experimentam o problema tão seriamente quanto os países pobres e as famílias menos privilegiadas. Esse tipo de violência é um fenômeno mundial que não respeita fronteira de classe social, raça, etnia, religião, idade e grau de escolaridade (PINHEIRO, 2000) é um fenômeno democraticamente distribuído (SAFFIOTI; ALMEIDA,1995).

Para Pinheiro (2000) e Casique e Furegato (2006), a violência é uma questão que está incrustada nas práticas culturais em todas as sociedades, independente do nível de renda ou de educação formal e submetida a uma contínua revisão na medida em que os valores e as normas sociais evoluem. “A determinação da violência diz respeito a um imbricamento de fatores históricos, contextuais, estruturais, culturais e interpessoais” (GUIMARÃES et al, 2006).

A violência doméstica contra a mulher possui variados tipos de manifestações e conseqüências que estão relacionados com a forma em que a mulher é agredida. Podemos 
diferenciar, de acordo com Azevedo (1985), três tipos de manifestações da violência doméstica contra a mulher: a física, a psicológica e a sexual, os quais discutiremos a seguir. Porém, é importante frisarmos que, apesar da divisão didática que os autores, geralmente, fazem, as formas de violência doméstica não são excludentes e, na prática, apresentam-se sobrepostas, com um ou mais tipos de violências verificadas em um mesmo caso (NEVES, 2004). Inclusive, existem autores que consideram outros tipos de comportamentos violentos, como Barnett (2000), por exemplo, que também considera como violência doméstica a negligência e a destruição de propriedade ou de animais de estimação.

\subsubsection{Violência física}

De acordo com Casique e Furegato (2006),

a violência física é entendida como toda ação que implica o uso da força contra a mulher em qualquer circunstância, podendo manifestar-se por pancadas, chutes, beliscões, mordidas, lançamento de objetos, empurrões, bofetadas, surras, lesões com arma branca, arranhões, socos na cabeça, surras, feridas, queimaduras, fraturas, lesões abdominais e qualquer outro ato que atente contra a integridade física, produzindo marcas ou não no corpo.

A violência física consiste na ação de agredir provocando desde pequenas lesões até traumatismo grave, levando, às vezes, até a morte. Day et al. (2003) afirmam que "na sua forma mais grave, a violência leva à morte da mulher. Sabe-se que de 40 a $70 \%$ dos homicídios femininos, no mundo, são cometidos por parceiros íntimos.” Os autores ainda complementam que o maior risco de ser a mulher assassinada pelo marido dá-se após a separação.

Em uma pesquisa desenvolvida por Deslandes (1999) com 72 mulheres que sofreram violência doméstica, as agressões físicas atingiram, sobretudo, a face e a cabeça em 27 casos, em 21 casos atingiram o braço e a mão porque as mulheres colocaram a mão para proteger a 
face, em 10 casos atingiram o corpo inteiro, em 4 casos foram no tórax e os outros 4, nos membros inferiores. O uso da força é o meio mais empregado pelos agressores em $70 \%$ das agressões, seguido de $21 \%$ em que foi usado algum tipo de instrumento, como pau, barra de ferro e porrete. A região dos olhos e da mandíbula foram as mais atingidas, sendo necessário o atendimento por ortopedistas, dentistas e oftalmologistas.

Um dos motivos da ocorrência da violência física é o rompimento na relação hierárquica estabelecida entre os gêneros, pois “na medida em que o poder é essencialmente masculino e a virilidade é aferida, freqüentemente, pelo uso da força, estão reunidas nas mãos dos homens as condições básicas para o exercício da violência” (SAFFIOTI, 1998, p. 57).

Após a mulher sofrer a agressão física ou sexual, geralmente, procura por profissionais da área de saúde em busca do tratamento das lesões corporais e das seqüelas psicológicas (RICHARDSON, FEDER, 1995; BEWLEY, MEZEY, 1997; HALL, LYNCH, 1998). Os ginecologistas e obstetras estão particularmente numa importante posição para identificar o abuso sexual, especialmente durante a gravidez (BARNETT, 2000).

Dentre os quadros orgânicos resultantes das agressões encontram-se lesões de variados tipos, distúrbios gastrintestinais, fibromialgia, aborto espontâneo e morte (DAY et al., 2003). Segundo Schraiber e D’Oliveira (2007), os médicos consideram os hematomas como a doença e a violência tende a ser desconsiderada. Mazoni (2007) afirma que os médicos tratam meramente as suas expressões sintomáticas, sem questionar suas verdadeiras causas, pois têm “dificuldade em trabalhar questões percebidas como culturais, sociais e até psicológicas” (SCHRAIBER, D’OLIVEIRA, 2007). De acordo com Sugg et al. (1999), o setor da saúde acaba compactuando com a invisibilidade social e, conforme Mazoni (2007) acaba “mantendo a violência contra a mulher 'cerrada’ entre quatro paredes”.

Manuais de identificação da violência doméstica são elaborados com o objetivo de instruir os profissionais da área da saúde para que as intervenções feitas com as vítimas sejam 
precisas e adequadas, e que possam ainda atuar como forma de prevenção a essa questão social (SALBER; TALIAFERRO, 1994).

Para Schraiber e D’Oliveira (2007), o médico, ao abordar o problema, deverá conversar com a mulher, expor as alternativas disponíveis para o caso, tanto para um acolhimento, quanto para a intervenção médica e decidir com ela quais são as melhores ações para se resolver essa questão, incluindo-a também na responsabilidade pelo destino de sua vida.

É muito importante que o profissional da saúde implique a mulher agredida nas decisões que ela deve tomar referente ao seu relacionamento abusivo, pois podemos enquanto mediadores institucionais tomar a frente da situação sem percebermos e assim, isentar a mulher de decidir e de se responsabilizar pela denúncia, por exemplo, ou até pelo retorno ao lar.

\subsubsection{Violência psicológica}

A violência psicológica ou agressão emocional pode ser tão ou mais prejudicial que a física (HEISE, 1994 apud GIFFIN, 1994), sendo caracterizada, de acordo com Azevedo (1985), por recriminações constantes como: desvalorização profissional, rejeição, depreciação, discriminação, humilhação, desrespeito e punições exageradas.

Wynter (apud CASIQUE; FUREGATO, 2006) classificou as diversas manifestações da violência psicológica:

- Abuso verbal: rebaixar, insultar, ridicularizar, humilhar, utilizar jogos mentais e ironias para confundir;

- Intimidação: assustar com olhares, gestos ou gritos, jogar objetos ou destroçar a propriedade; 
- Ameaças: de ferir, matar, suicidar-se, levar consigo as crianças;

- Isolamento: controle abusivo da vida do outro por meio da vigilância de seus atos e movimentos, escuta de suas conversas, impedimento de cultivar amizades;

- Desprezo: tratar o outro como inferior, tomar as decisões importantes sem consultar o outro;

- Abuso econômico: controle abusivo das finanças, impor recompensas ou castigos monetários, impedir a mulher de trabalhar embora seja necessário para a manutenção da família.

Para Day et al. (2003), esse tipo de violência deixa seqüelas mais graves do que as físicas, porque “destrói a auto-estima da mulher, expondo-a a um risco mais elevado de sofrer problemas mentais, como depressão, fobia, estresse pós-traumático, tendência ao suicídio e consumo abusivo de álcool e drogas”. Casique e Furegato (2006) citam outras conseqüências para a saúde da mulher como: ansiedade, distúrbios da alimentação e do sono, sentimentos de vergonha e culpa, síndrome do pânico, inatividade física, baixa auto-estima, tabagismo, comportamento sexual inseguro e autoflagelação.

Na pesquisa realizada por Kronbauer e Meneguel (2005) com 251 mulheres em uma unidade de saúde em Porto Alegre, Rio Grande do Sul, foi observada a prevalência de violência psicológica em 55\% dos casos, ou seja, 139 mulheres relataram ter sofrido pelo menos algum episódio de insulto, humilhação, intimidação ou ameaças por parte do companheiro.

Segundo Kaukinen (2004), o que pode favorecer a probabilidade do abuso psicológico é a incompatibilidade do nível socioeconômico dos parceiros, pois quanto maior o nível educacional deles, menor o seu risco de sofrer tanto a violência física como a psicológica.

Giffin (1994) concluiu em seus estudos que diferenças profissionais e educacionais entre casais aumentam o risco das agressões físicas e psicológicas. Anderson (1997) afirma 
que, nos Estados Unidos, um maior nível econômico e de status da mulher em relação ao seu parceiro aumenta o risco do parceiro cometer homicídio.

Uma das formas de violência psicológica, a agressão verbal, é de acordo com Oliveira, Barsted e Paiva (1984), algo corriqueiro, um tipo de ocorrência que a polícia não registra e que não desperta interesse das pessoas agredidas em denunciarem o agressor. Inclusive, uma revisão da literatura citou 25 estudos mostrando que a polícia, na maioria das vezes, ignora chamadas referentes à violência doméstica (BARNETT, 2000).

De acordo com Ballone (2002), a violência psicológica tem como objetivo “mobilizar emocionalmente o outro para satisfazer a necessidade do agressor de atenção, carinho e de importância”.

Segundo Barnett (2000), os homens agressores têm dificuldade de reconhecer o abuso verbal e psicológico como uma violência. Eles não pensam no medo que eles promovem com suas ações e acham esse tipo de comportamento o mais difícil de mudar. Conforme a autora, muito do trabalho realizado com esses agressores fica em torno deles poderem reconhecer essas formas de intimidação como um abuso, da mesma forma que a violência física é reconhecida.

Neves (2004) acredita que a violência psicológica é a que mais acontece, apesar da violência física ser mais facilmente reconhecida, pois muitas mulheres ainda não sabem identificar quando são vítimas desse tipo de violência, ao contrário das marcas no corpo que a violência física deixa.

Percebemos que tanto o homem como a mulher apresenta dificuldades em distinguir a violência psicológica em meio à convivência familiar, o que nos sugere a implementação de projetos educativos à comunidade para que ela aprenda a se relacionar, evitando esse tipo de agressão e também a identificá-la, caso seja necessário, a fim de se proteger. 


\subsubsection{Violência sexual}

De acordo com o Instituto Patrícia Galvão (2007), violência sexual é:

toda ação que obriga uma pessoa a manter contato sexual com outra pelo uso da força, intimidação, coerção, chantagem, suborno, manipulação, ameaça ou qualquer outro mecanismo que anule ou limite a vontade pessoal. Considera-se como violência sexual também o fato de o agressor obrigar a vítima a realizar alguns desses atos com terceiros.

O ato sexual é visto como um dever conjugal em que a mulher tem a obrigação de ter relações sexuais com o companheiro quando por ele solicitado, o que faz com que ele a induza ao sexo independente de sua vontade, caracterizando uma opressão de gênero, oriunda do poder patriarcal, em que a mulher é tratada como objeto de desejo masculino (SAFFIOTI, 1994; CAVALCANTI, ZUCCO, SILVA, 2007; OLIVEIRA, 2007). Esse pensamento favorece a violência sexual no casamento como algo “natural” e, conseqüentemente, “normal”, o que configura o uso "legítimo” da autoridade marital. Em razão disso, as mulheres não relatam esse tipo de violência sofrida por sentirem vergonha. Com isso, as mulheres agridem a si próprias permitindo o ato sem vontade porque aprenderam que esta é a sua obrigação (SAFFIOTI, 1987).

Na pesquisa realizada por Kronbauer e Meneguel (2005) na unidade de saúde do Rio Grande do Sul, referente à violência sexual, verificou-se que em 9\% dos casos, as mulheres já foram forçadas a práticas sexuais humilhantes ou ainda a estupros.

Dois estudos realizados com mulheres agredidas, moradoras de abrigos indicaram que seus maridos a violentaram sexualmente em $44,3 \%$ dos casos no primeiro grupo e $32 \%$ no segundo grupo (CAMPBELL, 1989; MARKWARD, 1996).

Outro aspecto que devemos destacar é o mito que enfatiza que o desejo sexual masculino é uma necessidade “natural” e, portanto, inevitável (ROCHEFORT, 1978; CAPLAN, 1987; JACKSON, 1987). Nesse entendimento, a idéia de que os homens têm um 
impulso sexual insaciável e maior torna-se um argumento usado para legitimar a violência sexual contra a mulher e também como justificativa para não responsabilizar o homem por tal ato (BIRKE, 1986).

Para Giffin (1994), essas diferenças entre a sexualidade masculina e a feminina garantem a hierarquia entre os gêneros em que o homem é o ser ativo e a mulher é o ser passivo, sendo negado à mulher o seu direito de decidir sobre seu corpo e sobre sua sexualidade permanecendo, assim, os ideais de sujeito versus objeto. Conforme o autor, a violência sexual objetifica e denigre as mulheres.

Além disso, existe a concepção de que a mulher é, geralmente, a responsável pela violência sexual por ser considerada sedutora e provocante, “constantemente tentando os homens a desviarem do caminho da razão e da moralidade” (SEIDLER, 1987, p. 87).

A mulher quando sofre esse tipo de violência deve denunciar o agressor, mas, geralmente, esconde tal ato para que a sociedade não a estigmatize e para não ficar desmoralizada publicamente (VERARDO, 2007b).

\subsection{Denunciar ou não?}

A partir do momento em que a mulher sofre a primeira violência, ela precisa denunciar o agressor, pois “o registro de uma queixa constitui a primeira providência em caso de agressão contra a mulher” (AZEVEDO, 1985, p. 33). Para Buckley (2000), ao tomar a iniciativa de denunciar, a mulher está evitando a reincidência do quadro e um possível agravamento das conseqüências. Assim, com a denúncia feita, a violência deixa de ser um fenômeno doméstico, algumas vezes invisível, para ser uma questão pública (SILVA, 1992). 
Dessa forma, a Delegacia da Mulher é o recurso legítimo para o enfrentamento do problema pela sociedade, defendendo os direitos das mulheres e buscando a mediação do conflito privado (SCHARAIBER, D’OLIVEIRA, 2007).

Quando as mulheres sofrem qualquer tipo de violência doméstica, elas devem denunciar o agressor, mas nem sempre isso acontece. A pesquisa do Núcleo de Opinião Pública nos mostra que os casos de denúncia pública são raros, ocorrendo principalmente diante de ameaça à integridade física por armas de fogo (31\%), espancamento com marcas, fraturas ou cortes (21\%) e ameaças de espancamento à própria mulher ou aos filhos (19\%). O órgão público mais utilizado para denúncias é a delegacia de polícia. A Delegacia da Mulher é mais utilizada nos casos de espancamento com marcas, fraturas ou cortes, mas ainda assim, infelizmente, por um pequeno índice de mulheres (5\%) (FUNDAÇÃO PERSEU ABRAMO, 2001).

Algumas mulheres que denunciam o marido querem, realmente, resolver a situação, pois “chegam a um ponto em que não podem mais tolerar o tratamento recebido" (VERARDO, 2007a). Em razão disso, após a denúncia, muitas mulheres temem em não voltarem para casa que, de acordo com Buckley (2000), Barnett (2000) é, na verdade, a primeira iniciativa que deve ser tomada pela vítima após uma agressão sofrida, evitando a reincidência do quadro e um possível agravamento das conseqüências. Por isso as mulheres tomam a iniciativa de morar na casa de algum parente próximo ou vizinho ou vão procurar por abrigos específicos para mulheres, vítimas de violência doméstica, mas, infelizmente, eles não se encontram em todas as localidades e os que funcionam estão sempre lotados. (SILVA, 1992). Conforme Barnett (2000), as mulheres agredidas encontram pouco suporte institucional ao deixarem uma relação abusiva e muitas delas não sabem sobre a existência de abrigos para as que estão em situação de risco. 
Após a saída de casa, Buckley (2000) e Almeida (1998) afirmam que o perigo da violência pode ser maior em alguns casos. Isso justifica o estudo de Warrington (2002) que trata da vida discreta e restrita que as vítimas levam após se separarem dos maridos e se refugiarem em abrigos ou se mudarem para uma nova casa em lugar diferente.

Outras mulheres apenas denunciam o marido porque esperam que a polícia dê uma advertência para que ele pare com a agressão, pois apenas querem cessar a violência para voltar a viver tranqüilamente como faziam até o momento em que a harmonia familiar foi rompida (MARINHEIRO, 2003). Assim, “a própria agressão física pode não ser o principal problema para algumas delas, já que a perturbação da ordem familiar que ela indica pode ser bem mais importante” (SCHARAIBER, D’OLIVEIRA, 2007).

Apesar de as mulheres terem conquistado o espaço público para denunciarem os agressores, muitas ainda desconhecem os seus direitos legais. Em alguns casos, as mulheres denunciam o marido, depois se arrependem e retiram a queixa porque percebem "nas queixas uma situação mais ‘social’ ou 'psicológica', desqualificando-as como crime” (SCHRAIBER, D’OLIVEIRA, 2007) ou por temerem represálias do marido, perda econômica e a posse dos filhos (RICHARDSON, FEDER, 1995).

Para Schraiber e D’Oliveira (2007), a retirada da queixa não é percebida pelas mulheres como contraditória ao movimento que as levou a registrá-la como crime passível de punição. Brandão (1996) ressalta que a retirada da queixa é fruto da "falta de consciência” das mulheres em relação aos seus direitos e de sua cidadania.

É muito comum algumas mulheres não denunciarem a agressão, e outras mulheres, geralmente, se calarem por muito tempo e quando decidem fazer a queixa já possuem uma vasta história de agressões que foram acumuladas há muito tempo. Normalmente, não é a primeira agressão que provoca a queixa (VERARDO, 2007a). As mulheres se calam ou 
demoram muito tempo a tomar a atitude de denunciar, isso se dá por vários motivos que dissertaremos a seguir.

Um dos motivos que a mulher ainda vivencia a violência dentro de casa é porque precisa se preparar efetivamente, preparar as condições de segurança e a auto-suficiência material, pois por falta de recursos financeiros, de um lugar para se refugiar e pela esperança de que o marido mude é que ela ainda mantém esse vínculo (CARDOSO, 1997; SOARES, 1999). Muitas pesquisas indicam uma dependência econômica que dificulta que a mulher deixe seu parceiro agressor. Em duas pesquisas com moradoras de abrigos, a probabilidade das mulheres ficarem nos relacionamentos abusivos era bem maior naquelas em que o parceiro era o único que obtinha alguma renda (BARNET, 2000).

Em um estudo com 141 moradoras de abrigos, pesquisas mostraram que a maioria das mulheres necessitava de bens materiais e serviços (84\%), suporte social (79\%), educação (71\%), atenção à saúde (70\%), assistência jurídica (62\%), emprego (62\%), transporte (58\%) e serviço de creche (57\%). Com isso, é provável que muitas mulheres agredidas que decidem retornar para seus parceiros agressivos percebam que as alternativas dentro do casamento são mais compensadoras, e o preço é menor do que as alternativas fora do casamento. (GONDOLF, 1999).

Em outros casos, algumas vítimas acreditam que não teriam crédito, caso denunciassem seu agressor, pois a própria sociedade estigmatizaria a queixa como sendo que a mulher que deu motivos para tal acontecimento (VERARDO, 2007a). De acordo com Cardoso (1997), outras não se atrevem a denunciar por temor das ameaças do agressor contra elas e seus familiares.

Algumas escondem e, justamente, não denunciam em razão da família, seja em nome da sacralidade, a fim de não deixarem de cumprir seus papéis de santa, de esposa, de mãe abnegada e exemplar e, conseqüentemente, de manterem o ideal de destino da mulher imposto 
pela sociedade patriarcal, pois falhar no casamento é pior do que manter uma relação de violência. Por acreditarem que precisam permanecer nessa relação abusiva pelo bem de seus filhos ou para garantir os direitos adquiridos através do casamento, elas se calam (VERARDO, 2007a).

Alsdurf (1985) afirma que o clero acredita que a maioria da população aceita as práticas da cultura patriarcal. Ele enviou um questionário para 5.700 ministros da Igreja Protestante nos Estados Unidos e Canadá. As respostas indicaram que 26\% dos pastores concordam que a mulher deve se submeter ao marido e confiar que Deus abençoará sua atitude, fazendo com que o parceiro pare de a agredir ou lhe dando maiores forças para suportar as agressões. E 50\% dos pastores preocupa-se que a agressão pelo marido não deve ser enfatizada pela mulher de forma exagerada e nem usada como motivo para separação. Um terço dos pastores acredita que as agressões devem ser muito severas para justificar que uma esposa cristã deixe seu marido. Somente $17 \%$ acredita que a constante violência física seria suficiente para que uma mulher se separe do marido.

Barnett (2000) identificou que os princípios morais são uma das razões para a permanência da mulher no lar abusivo. Conforme a autora, algumas mulheres preocupam-se com a imagem negativa de ser divorciada e com o estigma social associada às divorciadas.

Algumas mulheres escondem que sofrem violência doméstica por sentirem medo, o que as impedem de se protegerem dos agressores que por sua vez agüentam ser maltratadas durante anos sem nada dizerem, mantendo o ciclo da violência impune (SILVA, 1992). Há também as que sentem vergonha porque sofrem a violência por pessoas de sua confiança e que estão dividindo parte de sua vida (MAZONI, 2007).

Azevedo (1995) cita outros exemplos em que as mulheres sofrem caladas a violência doméstica, tais como: por acharem que "foi só daquela vez” ou que, no fundo, são elas as culpadas pela violência; tem também aquela idéia do "ruim com ele, pior sem ele”; outras não 
falam nada porque têm medo de apanharem ainda mais ou porque não querem prejudicar o agressor, que pode ser preso ou condenado socialmente.

A mulher ao não denunciar o marido contribui para a "conspiração do silêncio" que sutilmente dá suporte à opressão feminina, tornando-se cúmplice da violência (AZEVEDO, 1985). E, conseqüentemente, contribui para perpetuar esse tipo de situação (VERARDO, 2007a). Apesar de a violência doméstica acontecer em todas as camadas sociais é nas populares que se torna pública decorrente das denúncias realizadas na delegacia, pois nas camadas altas da sociedade, as mulheres mantêm o anonimato e procuram atendimentos particulares (SILVA, 1992).

\subsection{Dados da violência doméstica contra a mulher e políticas públicas}

Os índices de violência doméstica contra a mulher preocupam especialistas de várias áreas em todo o mundo, pois a mulher agredida, além de necessitar de socorro como assistência médica, psicológica e jurídica, provoca também um déficit no sistema econômico, devido, entre outros fatores, por faltarem ao emprego, queda na produtividade e desistências de cargos (BUCKLEY, 2000).

Em 1995, o U.S. Merit Systems Protection Board estimou um custo dos abusos sexuais para o governo dos Estados Unidos da ordem de 327 milhões de dólares, ao longo de dois anos quando o estudo foi feito (1992 a 1994), apenas em transferências de empregos, licenças médicas e quedas dos níveis de produção individual e grupal (MILLER; COHEN, 2004).

No Canadá, há um número significativo de mulheres agredidas por seus parceiros. Mais da metade das mulheres que foram assassinadas pelos seus companheiros já havia prestado queixas de violência nas delegacias, numa média de 35 vezes. Todo ano, mais de 
90.000 mulheres e crianças canadenses são admitidas em abrigos destinados a mulheres violentadas (COLLEMAN, 1999).

No Peru e no Paquistão, se uma mulher que sofreu abuso vai até uma delegacia de polícia para prestar queixa corre o riso de ser estuprada pelos policiais (KIRK, 1992).

Em Belgrado, uma análise de 770 chamadas de um 0800 para pedido de socorro mostrou que $83 \%$ dos casos de estupros são cometidos pelos maridos, companheiros ou namorados (MRSEVIC; HUGHES, 1997).

Óneil (1997) considera a violência doméstica nos Estados Unidos como a maior ameaça à saúde da mulher. O pesquisador acredita que ao invés de se pensar a causa focada nas questões individuais masculinas, ou seja, do agressor, deve-se ter em mente um modelo multifatorial que se divide em quatro áreas: 1) explicação macrossocial, cultura de dominância masculina; 2) explicação biológica do ser humano, instinto e impulso agressivo; 3) explicação dos papéis sociais de gênero. 4) explanação da relação entre os gêneros.

Gondolf (1997), que discute a diferença de gênero na Rússia e sua relação com os homicídios de esposas no país, também acredita em um modelo multifatorial com o qual associa os homicídios de mulheres cometidos por parceiros. O autor define tal modelo através dos seguintes fatores: alto nível de desorganização social, normalização e banalização da violência e desigualdade entre os gêneros.

Barnett (1997) concluiu através de seu estudo sobre o controle e a autodefesa que, na agressão entre parceiros, o aspecto motivador do comportamento agressivo masculino é o desejo de controlar a mulher, que por sua vez, agride o homem para se defender. Os homens entrevistados na pesquisa relataram amedrontar suas parceiras, freqüentemente, além de serem mais preocupados em controlá-las. 
Para Hamberger (1997), as motivações do uso da violência se relacionam com a dominação e o controle. Isso inclui controle físico, punição por um comportamento da mulher reprovado pelo homem, imposição e coerção emocional.

Stover (2005), da Yale University Child Study Center, acredita que os primeiros estudos sobre a violência de gênero ajudaram no entendimento da natureza do agressor, do ciclo da violência e nas conseqüências disso para as crianças que conviveram com o problema. Porém, mais recentemente, os estudos estão sendo focados na evolução das intervenções realizadas pelos profissionais de saúde e seus efeitos nos casos reincidentes.

Shepard (2005) acredita que, nos últimos vinte anos, grandes progressos foram alcançados nas estratégias de combate à violência contra a mulher e que as reformas institucionais tiveram um importante impacto positivo nesse processo.

No Brasil, a violência contra a mulher é um preocupante fato social, sendo apontada pela Anistia Internacional como um dos graves problemas de Direitos Humanos (NAÇOES UNIDAS, 2004).

Saffiotti (1998) buscou traçar um panorama da violência doméstica no Brasil, a partir do estudo de 170.000 Boletins de Ocorrências registrados em todas as Delegacias de Defesa da Mulher (DDM) de 22 capitais. Os resultados mostraram que 81,5\% dos casos referem-se a lesões corporais dolosas; metade das mulheres tem entre 30 e 40 anos e $30 \%$ das mulheres têm entre 20 e 30 anos; em 50\% dos casos, o casal tem entre dez e 20 anos de convivência, e em $40 \%$, entre um e dez anos, e que depois da queixa, $60 \%$ dos casais permanecem juntos.

A violência doméstica física é duas vezes maior para a mulher do que para o homem (32\% para 10\%), e isso sinaliza uma intensa cronificação da violência de gênero em um número significativo de casos como, por exemplo, na faixa etária de 18 e 29 anos, em que o espancamento é acintosamente freqüente. As estatísticas revelaram que os conhecidos são mais perigosos que os estranhos e que a mulher é a vítima preferida dos agressores familiares, 
além de ser justamente essa agressão que recebe menos atenção da sociedade (SAFFIOTI; MUÑOZ-VARGAS, 1994). Com isso, Pavez (1997) aponta que a violência doméstica é uma “questão de políticas públicas, de direitos humanos, sociais e de saúde”.

As políticas públicas e serviços de atendimento às mulheres em situação de violência, como abrigos, Delegacias de Defesa da Mulher, Organizações Não-Governamentais (ONGs) começaram a ser implantados no Brasil em decorrência das pressões desenvolvidas pelo Movimento Feminista.

As Delegacias de Defesa da Mulher e as casas-abrigo disseminaram-se por todo o país, sendo que no Estado de São Paulo foram instituídas 133 DDMs; na capital paulista são 29; e em todo o Brasil são aproximadamente 400, nos quais relevantes estudos são realizados para o aprimoramento dos atendimentos às vítimas e atualização dos dados da situação de violência no país (SAFFIOTI; MUÑOZ-VARGAS, 1994).

Essas delegacias significam um avanço importante da sociedade, não apenas enquanto conquista de um espaço para tornar visível o fenômeno da violência no país, mas, principalmente, pela possibilidade de essas mulheres serem atendidas por advogados, psicólogos, assistentes sociais e de obterem informações e orientações para que tenham melhores condições de buscar soluções adequadas para seus problemas.

A casa-abrigo foi criada para proteger a vida da mulher, interromper o ciclo de violência para dar condições de vida a ela e aos seus filhos, propiciar orientação jurídica, social e psicológica, atendimento à saúde e dar às crianças um espaço socioeducativo. Apesar de ser um local para a mulher se abrigar e se proteger contra o agressor, não deixa de ser um sofrimento, pois ela precisa sair do seu meio e se adaptar em outro, mesmo que provisoriamente (RECHTMAN, PHEBO, 2006). Gondolf (1999) descobriu que 24\% das mulheres abrigadas planejam voltar para seus lares e 7\% encontram-se indecisas. 
As Organizações Não-Governamentais (ONGs) são entidades criadas para atenderem à violência contra a mulher com a finalidade de que as mulheres conheçam seus direitos por meio dos atendimentos (DINIZ, 2007). Para os agressores, algumas casas-abrigo realizam trabalhos de encaminhamento à clínica psicológica, serviços de Núcleo de Apoio à Família ou para tratamentos específicos, como os de álcool, drogas, entre outros. Normalmente, a política pública defende a mulher, deixando o agressor à parte de todo o tratamento, mas é extremamente necessário dar respaldo a ele, visando a tratar o cerne do problema que gerou a violência (JAIME, 2006).

Em suma, o relacionamento abusivo tem como causas o efeito dos estereótipos e papéis impostos pela sociedade e a desigualdade de poder entre homens e mulheres dentro de casa e no seu relacionamento. A agressão acontece, pois de alguma forma a sociedade consente (BARNETT, 2000). 


\title{
3 GÊNERO: ASPECTOS BIOLÓGICOS OU SOCIAIS?
}

\author{
"Que a afetividade, a emoção, a ternura possam aflorar sem \\ constrangimentos nos homens, e serem vivenciadas nas mulheres como \\ atributos não desvalorizados”.
}

(PEDRO, 2002,p.26)

Apesar das divergências e dos impasses na conceituação do termo gênero, consideramos de fundamental importância sua discussão para o estudo da violência doméstica contra a mulher, à medida que as construções socioculturais dos papéis do homem e da mulher influenciam sobremaneira as relações de poder entre ambos.

O termo gênero começou a ser utilizado pelas feministas americanas com o objetivo de diferenciar o processo de construção social do sujeito da sua caracterização biológica, ambos determinados apenas pelo termo sexo ou diferenças sexuais (PEDRO, 2002). Assim, enquanto sexo refere-se à identidade biológica de uma pessoa, gênero está ligado a sua construção social como sujeito masculino ou feminino (LOURO,1996).

Azevedo (1985), Viezzer (1989) e Silva (1992) afirmam que essa diferenciação fisiológica constrói uma ideologia de formação sociocultural que cria estereótipos necessários à manutenção do atual padrão não-igualitário das relações entre homens e mulheres. Portanto, segundo, Saffioti (1987) a diferenciação dos papéis masculinos e femininos impostos pelas sociedades baseia-se mais em critérios socioculturais do que biológicos. De certa maneira, trata-se de uma distinção que induz ao erro, porquanto ignora que o sexo é também um conjunto socialmente construído de idéias moldadas pela cultura (JOHNSON, 1997 apud PEDRO, 2002).

Scott (1989), Viezzer (1989), Saffioti (2004), Laurentis (1994), Louro (1996) e Bourdieu (1995) conceituam o gênero como elemento constitutivo das relações sociais, baseado nas diferenças percebidas entre os sexos como uma forma primeira de significar as relações de poder. 
Com isso, de modo geral, os valores e prerrogativas culturais que definem o papel sexual masculino tradicional é o poder, a dominação, a força, a violência e a superioridade. Os valores e prerrogativas culturais que definem o papel da mulher são: a submissão, a passividade, a fraqueza, a inferioridade, a emoção, a fragilidade, a resignação e a insegurança que, inclusive, são apresentados como inerentes à mulher (SAFFIOTI, 1987; SCOTT, 1989; PAVEZ, 1997).

Como tais atributos tidos como naturais nas mulheres ou nos homens são, na verdade, características socialmente construídas, é indispensável demonstrar que, ao longo dos tempos, uma "naturalização” do social foi produzida. Porém, não podemos esquecer que a construção dos gêneros também envolve o corpo e, com isso, podemos supor uma estreita e contínua imbricação do social e do biológico na compreensão de gênero (LOURO,1996).

Nessa linha de raciocínio, Bordieu (1990 apud LOURO, 1996) fala da "somatização das relações de dominação”, com o objetivo de demonstrar o quanto se inscrevem nos corpos dos sujeitos dominados, no caso das mulheres, determinados gestos, posturas, disposições ou marcas da sua submissão. Segundo Barnett (2000), as qualidades mais valorizadas nas mulheres como tolerância e comprometimento acabam sendo responsáveis pela patologização de seus relacionamentos.

O termo gênero é tomado, conforme Louro (1996), muito freqüentemente como somente uma aprendizagem de papéis masculinos e femininos. Porém, para a autora gênero é mais do que uma identidade aprendida e do que papéis a serem desempenhados. Ele é constituído e instituído pelas relações sociais, pelas instituições, pelos símbolos, pelas formas de organização social, pelos discursos e doutrinas. E, por outro lado, essas diversas instâncias sociais também são instituídas pelo gênero.

Para Giffin (1994), é na família que a construção de gênero se organiza, pois encontra “um terreno privilegiado para o aprendizado de normas e valores, inclusive, os da violência” 
(PRADO, OLIVEIRA, 1982, p. 8). Neves (2004) afirma que a definição de ser homem ou de ser mulher submete-se à socialização de gênero, com base nas expectativas que a cultura tem e atribui a cada sexo. A família é o espaço privilegiado onde os modelos sexuais são desenhados e construídos pelas relações de poder.

Figueira (1987), Bellotti (apud SAFFIOTI; ALMEIDA, 1995), Pavez (1997) e Bourdieu (1995) afirmam que há uma construção social das diferenças entre homens e mulheres ainda quando estão sob os cuidados maternos, em que se institui que a mulher deve aprender a ser feminina e o homem a ser viril. Falconnet e Lefaucheur (1977) e Boudieu (1995) afirmam que a sociedade nos “exige” que a feminilidade deve ser um estado conservado pela mulher, e a virilidade deve ser manifestada pelo homem sem cessar.

Chodorow (1979) mostra as implicações do papel maternal na construção da identidade da criança. As meninas seguem os passos da mãe, tornando-se pequenas mulheres, ou seja, as meninas desenvolvem sua identidade de gênero no contexto da identificação com a mãe. Para os meninos, a masculinidade é aprendida como um conjunto de direitos e deveres abstratos, ficando sob os cuidados maternos até entrarem na puberdade, quando devem aprender a ser homem, desligando-se, então, de sua mãe e das qualidades femininas para desenvolver sua identidade masculina.

Segundo Barnett (2000), a masculinidade é caracterizada pela independência e competência, enquanto feminilidade é caracterizada como interdependência. Enquanto os meninos temem fracassar, as meninas temem serem bem-sucedidas.

De acordo com Alves e Pitanguy (1981 apud PEDRO, 2002),

o 'masculino' e o 'feminino' são criações culturais e, como tal, são comportamentos aprendidos através do processo de socialização que condiciona diferentemente os sexos para cumprirem funções sociais específicas e diversas. Aprendemos a ser homens e mulheres e a aceitar como 'naturais' as relações de poder entre os sexos. 
Em razão dessa construção social do que é ser homem e do que é ser mulher, são atribuídos, ao longo dos séculos, os papéis que devem ser assumidos por ambos (SCOTT, 1989; VIEZZER, 1989; PAVEZ, 1997; BOURDIEU, 1995; TELES, MELO, 2002). As mulheres "recebem a outorga de um universo próprio — o mundo doméstico (AZEVEDO, 1985. p.46). E os homens atuam no mundo público, ou seja, "no mundo do trabalho e no mundo da política” (AZEVEDO, 1985. p. 46). Isto é, a vida das mulheres é privada e doméstica e a dos homens, pública e social (ROSALDO, 1979). Vale ressaltar que o espaço doméstico tem sido reservado para a mulher sob a justificativa de sua capacidade natural de ser mãe (SAFFIOTI, 1987; SILVA, 1992; PAVEZ, 1997).

Dados empíricos nos mostram que a cultura patriarcal contribui para a agressão contra as esposas pelas seguintes crenças: o homem tem o direito de determinar se sua esposa pode ou não trabalhar; o homem tem o direito de decidir se sua esposa pode sair de casa à noite; é importante mostrar à esposa que ele é a cabeça do lar; o homem tem o direito de ter relações sexuais com sua mulher, mesmo se ela não desejar (SMITH, 1990).

Na verdade, a dominação masculina é uma dominação simbólica, legitimada pela sociedade que ainda se constitui patriarcal. Entendemos esse poder como "uma ação que é exercida constantemente entre os sujeitos e que supõe, intrinsecamente, formas de resistência e contestação” (FOUCAULT apud LOURO, 1996, p. 16). Portanto, há uma hierarquia entre os sexos que é fundamentada na superioridade e no poder masculino. É a partir desse modelo de desigualdade que explicamos a violência exercida pelo homem em relação à mulher.

Coleman e Straus (1986) analisaram relacionamentos conforme o poder do marido, conflitos e violência em 2.143 casais americanos. A pesquisa encontrou que quando há igualdade, ou seja, o poder é dividido entre marido e mulher, a relação apresenta menores níveis de conflitos e agressões. Estudos sobre o poder, o controle e o domínio sugerem que a violência acontece devido à necessidade de o homem ter o controle ou de não sentir-se fraco. 
Essa divisão binária entre masculino e feminino é uma construção simbólica e não uma imposição da natureza (RAGO, 2007b), ou seja, é a construção sociológica, política e cultural do termo sexo (CASTRO, 1992). Inicialmente podemos pensar que masculino e feminino são pólos opostos que operam por base de princípios fundantes. Mas Louro (1996) afirma que essa dicotomia deve ser “descontruída”, pois devemos demonstrar que um está presente no outro, ou seja, há uma interdependência entre os pólos.

Eaglenton (1983, p. 143 apud ROSALDO, 1979) sintetiza essa idéia de continuidade entre homem e mulher ao escrever que:

A mulher é o oposto, o 'outro' do homem: ela é o não-homem, o homem a
que falta algo, a quem é atribuído um valor, sobretudo, negativo em relação
ao princípio primeiro masculino. [...] A mulher não é apenas um outro ser,
no sentido de alguma coisa fora de seu alcance, mas um outro intimamente
relacionado com ele, a imagem daquilo que ele não é, portanto, uma
lembrança essencial daquilo que ele é. Assim, o homem precisa desse outro,
mesmo que o despreze, e é obrigado a dar uma identidade positiva àquilo
que considera como não-coisa, como nada. [...] Talvez ela represente um
signo de alguma coisa no homem que ele precisa reprimir, expulsar para
além de seu próprio ser, relegar a uma região seguramente estranha, fora de
seus próprios limites definitivos. Talvez o que esteja de fora também esteja,
de alguma forma, dentro, talvez o que seja estranho seja também íntimo -
de sorte que o homem precise policiar com atenção a fronteira absoluta entre
as duas esferas, porque ela pode ser sempre atravessada, sempre foi
atravessada e é muito menos absoluta do que parece.

O pensamento sobre a dicotomia entre homem e mulher visto como dois pólos opostos deve ser desconstruído como afirma Louro (1996) para dar lugar à idéia de continuidade, complementaridade entre ambos, pois somente assim será possível desmistificarmos os conceitos de gênero forte, dominador ou de fraco e submisso. Com certeza, o desafio é grande, pois em meio a tudo isso existe o preconceito contra a mulher, porém a luta deve continuar e a solidariedade entre os sexos deve ocupar o lugar da violência e quem sabe assim possamos perceber a linha tênue que separa o homem da mulher e que ao mesmo tempo os atravessa. 


\section{OBJETIVOS}

\subsection{Objetivo Geral}

- Investigar as percepções de mulheres agredidas pelos parceiros sobre os episódios de violência, suas justificativas do porque as agressões acontecem e os efeitos disso na vida delas.

\subsection{Objetivos Específicos}

- Verificar como elas se percebem e como percebem seus parceiros;

- Identificar quais sentidos atribuem aos seus relacionamentos;

- Compreender como as percepções das mulheres entrevistadas influenciam na sua permanência ou não com o parceiro agressor. 


\section{O PERCURSO METODOLÓGICO}

A presente pesquisa define-se pelo método qualitativo. Conforme Turato (2003), os métodos qualitativos têm como objeto as significações ou os sentidos do comportamento, das práticas e das instituições realizadas ou produzidas pelos seres humanos.

Para Bogdan e Biklen (1997), os pesquisadores qualitativos não entendem o seu trabalho como um compilamento de fatos sobre o comportamento humano, o que na verdade, proporcionaria um modo de verificar e elaborar uma teoria que estabelecesse relações de causalidade e previsões sobre o comportamento humano, exatamente como é feito na pesquisa quantitativa. Esses pesquisadores pensam que o comportamento humano é demasiadamente complexo para que tal mister seja possível, assim, acredita-se que a busca de causas e predições dificulta a capacidade de apreender o caráter essencialmente interpretativo da natureza e experiências humanas. Eles tentam compreender como os significados das pessoas são construídos, descrever em que consiste os mesmos e, para isso, recorrem à observação empírica por considerarem que é em função do comportamento que se pode refletir com maior clareza e profundidade sobre a condição humana.

\subsection{0 campo de investigação}

A investigação qualitativa tem como fonte direta de dados o ambiente natural onde se encontra o objeto de estudo, e o pesquisador é o instrumento principal dela (TURATO, 2003).

Turato (2003) afirma que, o campo da pesquisa qualitativa pode ser definido como o espaço físico onde o pesquisador julga serem regularmente encontradas, como sendo seu ambiente natural, as pessoas que poderão falar com autoridade sobre o tema definido em seu 
projeto de pesquisa e onde poderá inter-relacionar-se com elas, com o objetivo de ouvir um discurso pertinente e observá-las em sua postura.

O local escolhido para a realização deste trabalho é a Delegacia de Defesa da Mulher da cidade de Ribeirão Preto, interior do Estado de São Paulo, que conta com aproximadamente 504.923 habitantes e se encontra entre os maiores municípios do Estado ${ }^{6}$. O município possui uma unidade da Delegacia de Defesa da Mulher (DDM) que, sob a supervisão do Grupo de Estudos e Atenção à Violência Doméstica e Agressão Sexual (GEAVIDAS) disponibiliza atendimento psicossocial às pessoas que procuram a Instituição. Acreditamos que nessa Delegacia seria possível encontrarmos mulheres dispostas a nos falar sobre as agressões sofridas por parceiros e o Projeto do GEAVIDAS nos ajudaria a nos aproximarmos delas.

O GEAVIDAS é um grupo que funciona no Hospital das Clínicas da Faculdade de Medicina de Ribeirão Preto-USP, formado por profissionais interessados na problemática da violência doméstica e agressão sexual. Um dos trabalhos do grupo é realizado na DDM por profissionais voluntários e estagiários dos cursos de Serviço Social da Universidade de Ribeirão Preto-UNAERP, coordenado pela professora e assistente social Regina Brito, e Psicologia da Universidade de São Paulo-USP, coordenado pela professora e médica Catalina Camas Cabrera e pela psicóloga Sônia Aparecida Pires de Oliveira. A pesquisadora participou deste projeto como co-supervisora dos estagiários da Psicologia durante o ano letivo de 2004 e também enquanto psicóloga no ano de 2005. Um outro aspecto que nos motivou a escolha desse local para a realização da presente pesquisa foi o desejo de investigar as concepções sobre violência das mulheres agredidas que decidem quebrar o silêncio, responsável pela perpetuação da agressão em seus lares, por meio da denúncia na Delegacia da Mulher.

\footnotetext{
${ }^{6}$ Dados retirados da página oficial da cidade: <http:www.ribeiraopreto.sp.gov.br> e também da página oficial da Universidade de São Paulo (USP): <http://www.usp.br>.
} 


\subsection{Coleta de dados}

Minayo (1993) afirma que a investigação qualitativa requer como atitudes fundamentais a abertura, a flexibilidade, a capacidade de observação e de interação com os atores sociais envolvidos. Por isso, acredita que são componentes do trabalho de campo duas categorias fundamentais nesse tipo de investigação: a entrevista e a observação participante.

Ainda de acordo com a autora, a observação participante pode ser considerada parte essencial do trabalho de campo na pesquisa qualitativa, sendo sua importância de tal ordem que alguns estudiosos definem-na não apenas como uma estratégia no conjunto da investigação, mas como um método em si mesmo para compreensão da realidade.

Turato (2003) ressalta que a literatura é copiosa em considerar que a entrevista semiestruturada tem o formato mais apropriado para o instrumento a ser utilizado nas pesquisas qualitativas. Para o autor, o pesquisador que se utiliza dessa perspectiva teórica indaga seu entrevistado sobre um assunto de contornos mais restritos, com o objetivo de que este traga idéias que lhe foram interiorizadas a partir de suas vivências pessoais.

Minayo (1993) acredita que a entrevista tornou-se um instrumento privilegiado de coleta de informações para as ciências humanas, pois possibilita que a fala revele condições estruturais de sistemas de valores, de normas e símbolos, de questões socioeconômicas e culturais e, principalmente, revele as representações de grupos determinados.

Portanto, elegemos como técnicas de coleta de dados da presente pesquisa: a observação participante e a entrevista semi-estruturada em profundidade, pelo fato de a pesquisa qualitativa permitir uma metodologia que abre espaço à interpretação e possibilita a emergência de significados e sentidos subjetivos. 


\subsubsection{Procedimentos da coleta de dados}

Fase 1 - Observação participante: uma construção pelo olhar

As observações foram realizadas na Delegacia de Defesa da Mulher durante o período do ano letivo de 2005, por quatro horas semanais. Um Diário de Campo foi elaborado a partir das vivências e impressões da pesquisadora sobre a instituição, seu funcionamento e os casos atendidos pela equipe do GEAVIDAS.

\section{Fase 2 - Entrevista: a conversação como produção de sentidos}

As entrevistas foram realizadas em um único contato, em que o entrevistador explicitou, individualmente, os objetivos do estudo, o anonimato da mesma e a garantia do sigilo sobre as informações coletadas.

O Certificado de Consentimento ${ }^{7}$ foi assinado por todos os participantes da pesquisa e se encontra com a pesquisadora.

A solicitação de permissão para a gravação da entrevista foi feita, e então, essa foi iniciada com perguntas flexíveis e sem rigidez na seqüência. As mesmas foram gravadas e transcritas na íntegra pela pesquisadora.

Os tópicos da entrevista abordaram aspectos como a família de origem da mulher, sua família atual (parceiro e filhos), os episódios de violência vivenciados, as expectativas com relação ao boletim de ocorrência e suas perspectivas para o futuro ${ }^{8}$.

\footnotetext{
${ }^{7}$ Vide Anexo C

${ }^{8}$ Vide Anexo D
} 


\subsection{Participantes}

A pesquisadora elegeu, para participarem do estudo, sete mulheres que foram encaminhadas para o atendimento psicossocial do GEAVIDAS, atendendo ao critério da saturação dos dados, proposto por (1993).

As mulheres são encaminhadas para o atendimento após realizarem a denúncia de agressão e o Boletim de Ocorrência. Vale ressaltar que não são todas as mulheres que ao prestarem queixa de violência são encaminhadas para o atendimento psicossocial do GEAVIDAS, e sim, apenas aquelas que, no entender das escrivãs que as atendem, necessitam de auxílio e apoio psicológico.

\subsubsection{Descrição das participantes}

A seguir dissertaremos brevemente sobre as participantes e sobre algumas peculiaridades de suas vidas. Gostaríamos de frisar que os nomes utilizados para a descrição das mesmas são fictícios.

\section{Priscila}

Às vezes tem vontade de se matar ou de matar o parceiro e ele diz que tem vontade de matála. Ela descobriu que seu parceiro arrumou uma amante quando ficou grávida. Sua filha de um ano e cinco meses arranca seus próprios cabelos, a pediatra disse que isso é devido à tensão que existe dentro de casa e às brigas do casal que acontecem na frente da criança. 


\section{Paula}

Acredita que seu marido quer dar uma de solteiro, pois depois que comprou uma moto mudou de comportamento, vai a festas sem ela e lhe cobra gasolina para levá-la em algum lugar. Ela achou em seu bolso papéis com telefone de garotas de programa. Tudo o que compraram juntos desde quando se casaram está no nome dele e agora ela quer se separar, porém ele diz que ela não tem nada, que não vai ficar com nada.

\section{Rose}

É o segundo casamento dela em que é agredida pelo parceiro. Apanhou do pai quando criança que bateu a vida inteira em sua mãe. Foi expulsa de casa pelo atual marido que deu uma festa após sua saída. Está morando de favor na casa de uma amiga com as duas filhas. O parceiro ameaça tirar-lhe a filha mais nova que é dele também.

\section{Débora}

Separou do marido por causa do vício dele com drogas e depois lhe deu uma nova chance, pois ele disse que tinha se voltado para Deus. Porém foi ela engravidar do segundo filho que ele voltou ao comportamento anterior, recomeçou a usar drogas, a agredi-la e a agredir as crianças. Ela ressalta que seu estado atual é tão lastimável que ele faz suas necessidades fora do vaso sanitário.

\section{Vânia}

Separou-se do marido, pois cansou de ser traída por ele. Ele começou a agredi-la após sua decisão de se separar dele. Ele seqüestrou sua filha de um ano e três meses. Seu parceiro já foi preso por homicídio e é usuário de drogas. Vânia sempre soube de tudo. 


\section{Júlia}

Júlia e Tadeu têm 21 anos de idade, ainda não têm filhos. Júlia apareceu na Delegacia da Mulher com o olho direito inchado e roxo. Estava com vergonha de ir ao médico, do que os outros iriam pensar sobre ela. Ela desculpou Tadeu pelo ato de agressão. Disse que ela o havia irritado. Deseja construir uma família com ele, ela quer casar no papel e ter filhos.

\section{Josi}

Josi é uma moça muito bonita. Sua mãe é enfermeira, pessoa muito respeitada na sua cidade. Seu marido é piloto de avião. Ele não bebe, não tem nenhum vício. Porém, a ofende de todas as formas possíveis. Sempre que ele fica nervoso ele a trata mal, chama-a de vagabunda. $\mathrm{Na}$ Delegacia de Polícia da sua cidade natal, Josi já tentou prestar queixa contra o marido, mas não foi respeitada. Acredita que na Delegacia da Mulher o tratamento dado às mulheres é diferente.

\subsection{Procedimentos de análise dos dados}

Na fase 1 de coleta de dados da pesquisa, que consistiu na observação participante, não houve análise específica dos dados, visto que as impressões vivenciadas pela pesquisadora fizeram parte da análise da fase 2, ou seja, das entrevistas.

Na fase 2, foi realizada a análise qualitativa dos discursos segundo os preceitos da Análise de Conteúdo de Bardin (1997) e (1993) que se divide em três etapas:

1) Ordenação dos dados ou pré-análise: é o momento em que são feitas a exploração e a organização detalhada de todo o material colhido no diário de campo e junto aos sujeitos; 
2) Classificação: todo o material transcrito é lido e relido, a fim de identificarmos as estruturas principais nos relatos dos sujeitos para a classificação dos temas relevantes e a construção das categorias;

3) Análise Final: é feito o tratamento dos resultados obtidos, por meio de inferências e interpretações do campo investigado.

Segundo Bardin (1997, p. 42), a Análise de Conteúdo pode ser definida como:

um conjunto de técnicas de análise das comunicações visando obter, por procedimentos sistemáticos e objetivos do conteúdo das mensagens, indicadores (quantitativos ou não) que permitam a inferência de conhecimentos relativos às condições de produção/recepção (variáveis inferidas) destas mensagens.

Acreditamos que o modelo de análise de dados proposto traz à tona as percepções e significados atribuídos pelas participantes sobre o mundo que as cerca, assim como sobre a violência sofrida e sua relação com o parceiro agressor, contribuindo dessa forma, para a construção de um saber sobre a violência doméstica contra a mulher e o porquê algumas delas permanecem com o parceiro agressor. 


\section{RESULTADOS}

\subsection{Fase descritivo-exploratória: o contexto da pesquisa}

\subsubsection{A Instituição}

Trataremos a seguir sobre a origem da Instituição, seus procedimentos e condutas de trabalho na apuração de delitos e crimes de sua competência ${ }^{9}$.

As Delegacias de Defesa da Mulher (DDM) foram uma importante conquista do movimento feminista. A primeira Delegacia de Polícia de Defesa da Mulher foi criada em São Paulo pelo então governador Franco Montoro através do Decreto de $n^{\circ}$ 23.769, de seis de agosto de 1985.

Em 1986, o mesmo governador promulgou o Decreto $\mathrm{n}^{\circ} 24.669$, de 30 de janeiro de 1986, criando a Delegacia de Polícia de Defesa da Mulher (DDM) nos municípios de Ribeirão Preto, São José dos Campos e Limeira.

No ano de 2005, a Delegacia de Polícia de Defesa da Mulher de Ribeirão Preto registrou mais de 4.000 ocorrências. Não obstante, atende, orienta e encaminha cerca de 400 pessoas mensalmente, cujo caso não seja de lavratura de ocorrência.

Apesar da relevância dos serviços prestados, a DDM trabalha com deficiência em seu espaço físico, quadro funcional, recursos tecnológicos, entre outros. Atualmente, trabalham na Delegacia, em Ribeirão Preto, uma delegada de polícia que assumiu o comando da Unidade no ano de 1989, quatro escrivãs de polícia, três investigadoras de polícia e um agente policial.

A Portaria DGP. $\mathrm{n}^{\circ}$ 11, de 30 de maio de 1997, considerando as peculiaridades das atribuições acometidas às Delegacias de Polícia de Defesa da Mulher, resolveu que,

\footnotetext{
${ }^{9}$ As informações nos foram fornecidas por funcionários da Delegacia de Defesa da Mulher. Vide anexo E para os crimes de competência da Delegacia de Defesa da Mulher.
} 
preferencialmente, para o exercício das funções seriam designadas policiais civis do sexo feminino.

Inicialmente, cabia à DDM a investigação e apuração dos delitos contra a pessoa do sexo feminino, previstos na Parte Especial, Título I, Capítulos II e VI, Seção I, e Título VI do Código Penal Brasileiro de autoria conhecida, incerta ou não sabida, ocorridas na área circunscricional.

Atualmente, o Decreto $\mathrm{n}^{\circ}$ 42.082, de 12 de agosto de 1997, alterando o Decreto $\mathrm{n}^{\mathrm{o}}$ 40.693, de $1^{\text {o }}$ de março de 1996, estabeleceu e ampliou à DDM as seguintes atribuições:

1) investigação e apuração dos delitos contra a pessoa do sexo feminino, a criança e o adolescente, previstos no Título I, Capítulo I, II, III e V e Seções I, II do Capítulo VI, nos artigos 163 e 173 do Título II, nos Títulos VI e VII, e no artigo 305 do Título X, todos da Parte Especial do Código Penal, e os crimes previstos no Estatuto da Criança e do Adolescente - Lei no 8.069/90;

2) atendimento de pessoas do sexo feminino, crianças e adolescentes que procurem auxílio e orientação e seu encaminhamento aos órgãos competentes;

3) cumprimento dos mandados de prisão civil por dívida do responsável pelo inadimplemento voluntário e inescusável de obrigação alimentícia.

No tocante aos artigos 121(homicídio simples) e 163 (danos à coisa alheia) do Código Penal, a competência se restringe às ocorrências havidas no âmbito doméstico e de autoria conhecida.

Referente ao funcionamento da DDM, a mulher ao procurar a Delegacia da Mulher é encaminhada à sala das escrivãs onde ela deverá contar detalhadamente o que ocorreu e a escrivã constará os fatos no Boletim de Ocorrência (BO $)^{10}$ ou no Termo Circunstanciado de

\footnotetext{
${ }^{10}$ O Boletim de Ocorrência é uma peça administrativa que noticia um fato, ou seja, a reclamação da vítima, para depois instaurar um inquérito policial para a apuração do caso. Esse documento é arquivado e encadernado em livros, seguindo a data, mês e ano vigente e fica guardado no cartório da DDM.
} 
Ocorrência (TCO) $)^{11}$. A mulher ao denunciar o parceiro deverá assinar um dos instrumentos jurídicos para que eles se tornem válidos.

Após o atendimento na delegacia, a mulher é encaminhada ao atendimento médico no caso de se encontrar ferida e, em casos de lesões corporais graves e estupros, ela deverá ser encaminhada para o Instituto Médico Legal (IML) para que seja feito o exame de corpo de delito. Nesse exame será constatado se ocorreu algum tipo de violência, como foi, qual o meio utilizado para a agressão, entre outros quesitos. Esse exame é de suma importância, pois ele ajuda a apurar a gravidade da agressão e ainda pode servir como prova do crime. A mulher não deve de maneira nenhuma, antes de procurar atendimento médico, tomar banho ou lavar o local ferido, pois isso poderá mascarar o exame.

Após todos esses procedimentos realizados pela mulher, ela deverá voltar à DDM com o laudo em mãos, para que ele possa ser anexado ao inquérito policial e o agressor ser chamado para depor. Com o término das apurações do inquérito, a delegada remeterá o resultado para o promotor de justiça, para que o agressor possa ser julgado, e no caso de ser considerado culpado, ser condenado.

A mulher deve apresentar sua queixa no Fórum no prazo de 180 dias, porém muitas não o fazem provocando com isso o arquivamento do inquérito policial resultante do BO Com isso, não se dá prosseguimento ao caso, o que gera impunidade nos casos das agressões domésticas e permite com que o ciclo da violência dentro de casa perpetue-se.

\subsubsection{Incursão a campo}

O Projeto do GEAVIDAS de prevenção à violência doméstica além de funcionar no Hospital das Clínicas da Faculdade de Medicina de Ribeirão Preto disponibiliza atendimentos

\footnotetext{
${ }^{11}$ O Termo Circunstanciado de Ocorrência contém a declaração da vítima e exterioriza o ato formal, possuindo força jurídica para gerar um processo penal. Esse documento é numerado conforme sua entrada e fica guardado em caixas de papelão também numeradas.
} 
psicossociais na Delegacia de Defesa da Mulher de Ribeirão Preto para as mulheres vítimas de violência. Os atendimentos são realizados por psicólogos e assistentes sociais, como já dito anteriormente, e tem como objetivo propiciar um acolhimento a essa mulher, para que ela se sinta respaldada por profissionais e quebre seu silêncio referente às agressões sofridas. A proposta dos profissionais é a de que algo sobre sua vida possa começar a ser pensando, percebido, “digerido” por ela e alguma direção possa ser tomada.

Os atendimentos são organizados em plantões e divididos entre os profissionais por dias da semana e turnos, matutino ou vespertino, com a proposta de ter na Instituição sempre alguém disponível para as mulheres que necessitem de ajuda e acolhimento.

No momento em que a mulher chega à Delegacia, ela faz o boletim de ocorrência com as escrivãs e, conforme o caso e a necessidade da mesma, a escrivã faz o encaminhamento para os profissionais do GEAVIDAS.

Na sala do GEAVIDAS, que foi um local que a própria delegacia nos destinou, exclusivamente para o serviço (o que significou uma grande vitória para nós), havia sempre a presença de duas profissionais: uma psicóloga e uma assistente social. A intenção era a de propiciar esse duplo atendimento para suprir as diversas demandas da mulher que procura ajuda.

A psicóloga é responsável pelas orientações de cunho psicológico e questionamentos adequados referentes ao caso, e a segunda pelos encaminhamentos para os diversos serviços públicos e visitas domiciliares quando conveniente. Ambas com a importante responsabilidade de ouvir a mulher atentamente, acolhê-la e direcioná-la.

A sala que nos foi destinada para o trabalho era espaçosa, tinha uma mesa com quatro cadeiras, um armário, algumas carteiras universitárias encostadas na parede, um móvel com brinquedos para crianças. Compartilhávamos o telefone da própria delegacia que era sem fio e não encontramos nenhum problema em dividi-lo com os demais funcionários dessa. A sala 
não era totalmente fechada, e sim, delimitada por uma divisória que não se encostava no teto, ficava um vão de aproximadamente 50 centímetros, portanto, o som dentro da sala não ficava completamente abafado, e assim nossas conversas, dependendo da altura em que a pessoa falava, não eram tão reservadas, dificultando a privacidade dos atendimentos realizados.

Um recurso interessante que tínhamos disponível para a execução do nosso trabalho era a intimação. Quando percebíamos a importância e a pertinência de ouvir o agressor, ou seja, o outro lado da história, preenchíamos uma intimação da própria delegacia, porém com o carimbo do GEAVIDAS, e os funcionários da delegacia mandavam-na no endereço solicitado. Isso fazia com que muitos agressores comparecessem para esclarecer o fato da violência e, na maioria das vezes, permitia um diálogo entre o casal que ambos não conseguiam ter em casa por meses, com a intermediação dos profissionais, facilitando e amenizando, assim, as coisas entre eles.

Num primeiro momento da pesquisa, decidimos por freqüentar a delegacia apenas para observar seu funcionamento e o trabalho da equipe do GEAVIDAS. Comparecíamos à Instituição toda segunda-feira das 9:00 às 13:00 horas. Vale ressaltar que já conhecíamos o trabalho do grupo, pois no ano anterior fomos co-supervisora, juntamente ao professor Sérgio Kodato, de alunas da Psicologia da USP que participavam do GEAVIDAS e faziam estágio na Delegacia.

Após três meses de observação, começamos a participar dos atendimentos e a realizar nossas entrevistas para a coleta dos dados da pesquisa. Notamos que pelo fato de ser psicóloga havia uma demanda da equipe do GEAVIDAS para que nós participássemos dos atendimentos, principalmente, quando não havia psicólogos nos plantões por imprevistos ou problemas de horários, pois, na verdade, nossa primeira intenção era ficar um tempo maior do que três meses, focada nas nossas observações. Interessante que no, ano de 2005 quando 
realizamos o trabalho a campo, a equipe tinha um número maior de assistentes sociais do que de psicólogos, o inverso do ano de 2004 que contava com um maior número de psicólogos.

Na tentativa de proporcionarmos uma noção da realidade da Delegacia e dos casos atendidos pela equipe do GEAVIDAS nos plantões, apresentamos a seguir, uma breve descrição de alguns casos atendidos ao longo das nossas observações a campo.

Gostaríamos de esclarecer que a maioria dos casos foi atendida apenas uma vez pela pesquisadora, pois o retorno da vítima, geralmente, é agendado de acordo com a disponibilidade da mesma e a do agressor, e isso depende também do dia em que a intimação feita pelo GEAVIDAS chegará à casa desse. Assim, alguns casos apresentados possuem mais informações do que outros.

\section{1) Filha de 17 anos abusada pelo pai há 10 anos.}

A mãe foi prestar queixa de abuso contra o pai e levou a adolescente para conversar conosco sobre a situação.

Nesse caso, chamamos o pai para conversar conosco e depois encaminhamos a família para psicoterapia.

\section{2) Mulher de 40 anos agredida pelo marido há 23 anos.}

Mulher foi à Delegacia dar queixa de agressão do marido e dizer que agora quer a separação, que “já não agüenta mais”. Disse que como seus filhos estavam todos crescidos, agora tem condições de se separar do marido.

“Agora eu não preciso mais dele, eu tô velha, as crianças já tão maiores, antes elas eram pequenas e eu precisava dele, podia revoltar as crianças”.

É importante ressaltar, como já dito anteriormente, que todo boletim de ocorrência de agressão feito pela mulher tem um prazo de 180 dias para que a queixa seja representada, ou seja, 
a mulher deve confirmar a queixa no Fórum. Em seguida, no caso dela decidir, realmente, pela separação, o agressor deve comparecer à delegacia ou ao Fórum para ser ouvido.

\section{3) Mulher de 42 anos é humilhada pelo marido há 17 anos e agora quer a separação.}

Mulher quer a separação agora, pois suas filhas são amasiadas atualmente.

“Antes tinha as crianças... eu agüentei porque meus filhos eram pequenos, agora eu não agüento mais não”.

Nesse tipo de caso quando a mulher quer tomar uma decisão importante sobre seu relacionamento conjugal, marcamos um ou dois retornos para conversarmos um pouco mais com ela, antes de encaminhá-la para psicoterapia e para um advogado.

\section{4) Mulher amasiada há 34 anos. Sofre agressões físicas do parceiro.}

M. ficou internada recentemente durante quatro dias, pois levou do marido uma copada na cabeça. Um fato interessante é que essa mulher foi até nós para pedir que tirássemos o marido dela da sua casa. Quando ela percebeu que não podíamos fazer isso, nos xingou, falou que não servíamos para nada, pois ela foi até a delegacia e voltaria para sua casa na mesma situação, sem resolver nada.

Percebemos durante nossas observações que muitas mulheres acreditavam que a delegacia, ou seja, nós e os outros funcionários tínhamos a obrigação de resolver o problema delas e ficavam muito desiludidas quando constatavam que a solução deveria partir delas.

\section{5) Mulher de 56 anos com transtornos psiquiátricos: falas desordenadas e alucinações.}

Foram muitos os casos que presenciamos de pessoas com sintomas psiquiátricos que recorrem à Delegacia para contarem sobre seus problemas ou suas histórias, que por muitas vezes, não tinham começo, meio e fim, nem conexão nas idéias. 
Nos casos em que notávamos alguns sintomas psiquiátricos, fazíamos encaminhamentos para a Psiquiatria do Posto de Saúde.

6) Mulher relata que seu marido bate nela quando se recusa a manter relações sexuais com ele.

F. conta, além do relato de agressão do marido, que foi abusada quando criança e que descobriu, recentemente, que seu marido levou sua vizinha para dentro da sua casa para ter relações sexuais com ela.

Marcamos um retorno conosco para F e a encaminhamos para psicoterapia.

\section{7) Casal foi ao atendimento, pois o marido foi intimado pelo GEAVIDAS devido à queixa de agressão feita pela esposa.}

A esposa diz que não se separa dele por causa de seu filho que gosta muito do pai, e o marido, por sua vez, faz também uma série de acusações contra sua mulher, sobre o seu jeito de ser.

Nesse caso, conversamos com o casal considerável tempo, na tentativa de conscientizá-los da importância de freqüentarem uma psicoterapia.

\section{8) Moço vai se defender de acusações feitas na DDM por uma mulher.}

Primeiramente, ouvimos a mulher que fez a queixa contra o moço de que ele estava perseguindo-a. Percebemos que ela nutre uma paixão por ele, além de apresentar transtornos psiquiátricos, de ser envolvida com drogas, bebidas e com muitos homens.

Logo depois, ouvimos o moço que disse conhecê-la apenas de vista e não saber o porquê dela ter feito tal acusação. 
Algumas mulheres vão até a Delegacia e deturpam suas histórias na ilusão de que por ser uma Delegacia da Mulher elas sempre terão razão em detrimento do homem e isso não ocorre. Os casos são analisados de forma neutra, sendo que nenhum gênero é privilegiado.

\section{9) Duas mulheres foram prestar esclarecimentos sobre um relacionamento cujo homem} é ex-namorado de uma e atual marido de outra.

O homem relacionou-se com as duas mulheres ao mesmo tempo por um determinado período, o que deixa a atual mulher insegura. Devido a isso ela, geralmente, faz ligações para a ex-namorada do seu marido a fim de se certificar se ele não está com ela, então, a ex foi até a DDM prestar queixa da atual mulher do seu ex-namorado. As duas mulheres foram chamadas para que nós pudéssemos intermediar a conversa delas e as ajudar a resolver essa situação. Elas discutiram muito durante o atendimento, mas conseguiram conversar algumas questões.

Acreditamos que, numa situação de conflito, um mediador pode facilitar o diálogo entre as pessoas envolvidas e promover entre elas acordos interessantes e saudáveis para ambos os lados.

10) Marido é chamado na DDM por ser acusado de violência contra sua esposa com a qual vive há 33 anos.

Ele é alcoólatra e muito ciumento relata a filha do casal que também estava presente. No entanto, ela diz que sua mãe avança para agredir o pai, grita com ele no meio da rua, fazendo-o passar vergonha. Ele faz algumas reclamações sobre o jeito que ela o trata e tenta justificar as agressões.

Conversamos com ele sobre as conseqüências das agressões entre um casal, tanto as emocionais quanto as jurídicas. Ele se mostrou aberto a nos escutar. 
11) Mulher presta queixa contra seu ex-namorado por ter molestado sua filha deficiente mental de 26 anos de idade.

T. foi à Delegacia denunciar seu ex-namorado pelo abuso de sua filha, porém teme que ele faça algo contra ela, pois ele diz que vai se vingar dela por ela não querer mais viver com ele.

Intimamos o moço para conversar conosco, porém ele não compareceu à Delegacia.

12) Menina de 14 anos e sua mãe foram até a Delegacia, devido, a primeira ter sido espancada pelo namorado por estar num ponto de prostituição com uma amiga de 19 anos.

A menina diz que não estava se prostituindo, mas sua mãe diz que vai expulsá-la de casa por causa disso. O namorado, por sua vez, tinha passagem pela polícia por tráfico de drogas e já tinha batido nela outras vezes por causa de ciúmes.

Tivemos muitos casos, ao longo desse ano, de mães que vão até à Delegacia reclamar de suas filhas adolescentes por causa de namorados e de rebeldia dentro de casa.Nesse caso, encaminhamos a menina para psicoterapia.

\section{3) Briga de vizinhos}

Um casal ameaçou outro casal, que mora na casa ao lado, com arma de fogo devido a excesso de barulho.

Notamos que briga de vizinhos é um caso que aparece na Delegacia com muita freqüência. Acreditamos que a situação chega num ponto em que as pessoas não conseguem mais dialogar e, então, precisam de um mediador institucional. 
14) Mãe se queixa da filha por agressão a ela e ao irmão dela de 4 anos.

Adolescente de 17 anos bate na mãe e no irmão quando é contrariada ou está nervosa. Ela dá socos, beliscões e chutes em ambos.

Intimamos a menina para conversar conosco e encaminhá-la para psicoterapia.

15) Mulher faz queixa de agressão contra seu marido que é alcoólatra e esquizofrênico.

C. tem um marido e um filho de 24 anos, ambos com esquizofrenia. O marido agridea, e seu filho não a defende. C diz que não agüenta mais essa situação.

Pedimos para que ela trouxesse seu marido para conversar conosco para encaminhá-lo à Psiquiatria.

16) Mulher casada há 27 anos sofre agressões do marido há 23 anos.

“Meus filhos estão criados, não tenho mais necessidade disso. Agora eu resolvi dar um basta”.

Mulher chega à Delegacia com intenção de se separar do marido devido há anos de agressões.

Conversamos com ela, marcamos um retorno antes de encaminhá-la para psicoterapia e indicamos um advogado para que ela pudesse se orientar juridicamente.

17) Mulher deu queixa contra agressão do marido alcoólatra.

O marido foi intimado para conversar conosco devido à queixa de sua esposa contra ele. Uma das filhas do casal veio acompanhar o pai para conversarmos sobre o ocorrido. A filha disse que sua mãe provoca muito seu pai e acaba tirando ele do sério, o que foi confirmado pelo marido. 
Conversamos com o marido sobre as conseqüências da agressão e, principalmente, do álcool. Nós o orientamos para que procurasse tratamento para o vício.

\section{8) Moça presta queixa contra parceiro.}

Moça de 23 anos mora com o namorado de 20 anos há três anos, com o qual tem dois filhos pequenos. Ele a agride há um ano.

Conversamos com ela sobre a situação e fizemos o encaminhamento dela para psicoterapia.

\section{9) Casal de namorados procura a DDM para receber orientação.}

A garota estava sendo perseguida há dois anos por um desconhecido que freqüenta a mesma faculdade dela. Antes ele a perseguia por meio de ligações telefônicas, porém recentemente tentou agarrá-la na rua.

O casal estava preocupado com a situação e queria uma orientação de como proceder nesse tipo de caso. Orientamos que eles fizessem um Boletim de Ocorrência sobre o fato.

\section{0) Mulher pede orientação para se separar do marido que a traiu.}

G. conta sobre a traição do marido e diz querer separar-se dele.

Indicamos a ela um advogado para cuidar do caso e orientamos que freqüentasse uma psicoterapia.

\section{1) Irmã faz queixa do irmão.}

E. diz ter um irmão que mora com a mãe deles. Ele maltrata a mãe e a agride verbal e fisicamente. Ele não permite a entrada da irmã na casa para dar medicação para a mãe que já tem idade avançada e tem a doença de Alzheimer. 
Nesse caso, intimamos o irmão de E. para conversar com ela e conosco com o objetivo de mediarmos o diálogo sobre uma possível resolução da situação.

22) Mãe de 32 anos faz queixa de abuso infantil contra padrinho de seu filho de 11 anos.

K. relata-nos que o padrinho de seu filho de onze anos abusou sexualmente dele. Esse homem que a mãe escolheu para ser padrinho de seu filho também abusou dela quando ela era criança.

Conversamos com ela sobre a situação e fizemos uma encaminhamento para ela e um para seu filho para psicoterapia.

\section{3) Mulher de 40 anos reclama da agressividade de filho de 21 anos.}

J. reclama que não consegue ser respeitada pelo filho que a agride sistematicamente.

Notamos que algumas pessoas procuram a DDM na expectativa de resolver problemas familiares que dependem apenas delas. Acreditamos que isso acontece devido a uma dificuldade das pessoas em lidar com certas situações, o que faz com que elas recorram a um mediador institucional, detentor de um poder legitimado pela sociedade.

\section{4) Mulher casada há 37 anos fala do marido que agride suas filhas e a ela também.}

M. conta-nos sobre as agressões do marido, porém não comenta sobre querer separarse, pois muitas mulheres falam em separação na hora da raiva, mas não tomam nenhuma atitude para que isso aconteça.

“Eu tenho que pensar em mim, mas nele também”.

Ouvimos sua história e fizemos seu encaminhamento para psicoterapia. 


\subsubsection{Supervisão dos atendimentos e o olhar das estagiárias}

Um outro aspecto que, também, nos aproximará da realidade da Delegacia de Defesa da Mulher são as questões discutidas em supervisões que se deram ao longo do ano de 2004, com as estagiárias de Psicologia do GEAVIDAS.

Uma questão importante nos foi colocada pela estagiária L que sente haver uma banalização das intimações, pois, conforme L, elas são enviadas para todos os casos, indiscriminadamente. Segundo ela, a intimação policial reflete uma onipotência em se querer resolver os problemas de todas as pessoas que vão até a delegacia. Um exemplo disso é o caso de uma mãe que foi ao atendimento buscar ajuda, pois tem um filho de 23 anos que não a obedece e, então, uma profissional intimou o filho para conversar sobre a falta de obediência dele. Foram intervenções como essas que, às vezes, aconteciam que nos fizeram pensar sobre qual o nosso papel dentro da Delegacia.

Acreditamos que devemos despertar algo na pessoa que pede ajuda para que ela própria possa tomar suas atitudes, com isso resolver seus problemas e amadurecer enquanto pessoa. E não nos dispormos a resolver seus problemas por elas, o que é muito diferente de sermos mediadores de conflitos.

Outro tema discutido intensamente durante as supervisões foi sobre quais são os objetivos da DDM. Chegamos à conclusão de que são:

- Escutar, no sentido de conter a angústia do outro;

- Orientar sobre condutas a serem tomadas, como quais profissionais buscar para cada tipo de caso e quais Instituições;

- Encaminhar as pessoas que nos procuram para serviços especializados;

- Se houver uma "brecha” na fala do sujeito, questioná-lo a fim de proporcionar reflexões sobre questões levantadas por ele durante o atendimento. 
Pensamos também sobre alguns cuidados que devem ser tomados pelo psicólogo, durante os atendimentos na delegacia:

- Não banalizar a intimação;

- $\quad$ Não se colocar no papel de policial, delegado, ou seja, não representar nenhuma figura da lei.

Houve duas questões que foram amplamente discutidas pelo grupo nas supervisões e que possuem grande relevância para que o atendimento na delegacia seja eficaz.

- Como o psicólogo é visto pelo sujeito que chega ao GEAVIDAS?

- Como é ser visto como representante da lei e quais as implicações disso?

Notamos que nós, psicólogos, e as assistentes sociais éramos tomados, freqüentemente, como representantes da lei dentro da Delegacia.

Discutimos com as estagiárias que as conseqüências de sermos vistos dessa forma faz com que as pessoas nos procurem com a expectativa de sermos investidos de poder policial para resolvermos todos os problemas delas, como o caso citado da mulher que era agredida pelo parceiro há 33 anos e foi nos pedir para tirá-lo da casa dela. Nosso trabalho, enquanto psicólogos, é o de implicar as pessoas em seus problemas, questionando-as sobre o que elas podem fazer no seu caso, mas algumas se encontravam muito distantes dessa reflexão, o que era mais agravado ainda pelo setting em si, pois estávamos numa Delegacia e não num consultório ou ambulatório de saúde.

Referente ao ambiente de trabalho da Delegacia de Defesa da Mulher, podemos dizer que por estar situada no mesmo prédio que o $1^{\circ}$ Distrito da Polícia Civil onde são realizadas ocorrências de todos os tipos de crime, o local era freqüentado por vários tipos de criminosos e infratores, desde indivíduos que cometeram simples infrações de trânsito até estupradores.

Houve um episódio que nos impressionou muito sobre um atendimento que realizamos de uma menina de nove anos que tinha acabado de ser estuprada por um homem desconhecido 
que pulou o muro da sua casa, onde a menina estava sozinha, invadindo-a e estuprando a menina. Conversamos com a menina que estava enrolada num roupão, com a mãe e com o pai dela que estavam desesperados. Por fim, a polícia prendeu o homem que foi levado até a Delegacia para prestar esclarecimentos sobre o caso. Esse atendimento fez-nos ficar sem ir à Delegacia por duas semanas, tamanha a mobilização de sentimentos que houve.

Concluímos, com a incursão a campo, que observar mulheres que chegam à DDM tendo vivido 20, 30 anos uma situação de violência dentro de casa e, de repente, de um momento para outro, exigem que outras pessoas resolvam o problema por ela, faz-nos refletir sobre como e com qual intensidade nos implicamos nas questões de nossa vida. Talvez não desejamos e nem tentamos sair de algumas posturas adotadas por nós, pois isso implicaria em repensar posições e atitudes, o que provocaria algumas perdas, mas, com certeza, ganhos também.

Trabalhar nesta pesquisa tendo como campo a Delegacia da Mulher mobilizou-nos os mais profundos sentimentos humanos: dor em ouvir o sofrimento do outro, raiva ao entrar em contato com o lado perverso do ser humano, compaixão pelas doenças que assolam nossa alma e nos desequilibram a mente, esperança por conviver com pessoas que lutam pelas causas sociais e admiração por conhecer mulheres que desejam melhorar suas vidas enfrentando as dificuldades.

Essa incursão a campo fez-nos refletir sobre a importância do psicólogo para a sociedade, sobre quantas ações sociais podemos nos engajar a fim de divulgar nossa profissão para que as pessoas saibam como recorrer a nós e, principalmente, o quanto podemos contribuir para a saúde psíquica da nossa comunidade. 


\subsection{Categorias e marcas discursivas}

O quadro abaixo foi elaborado, a partir da leitura e releitura dos discursos das mulheres entrevistadas. As categorias foram divididas em cinco classes para melhor compreensão dos dados resultantes das entrevistas.

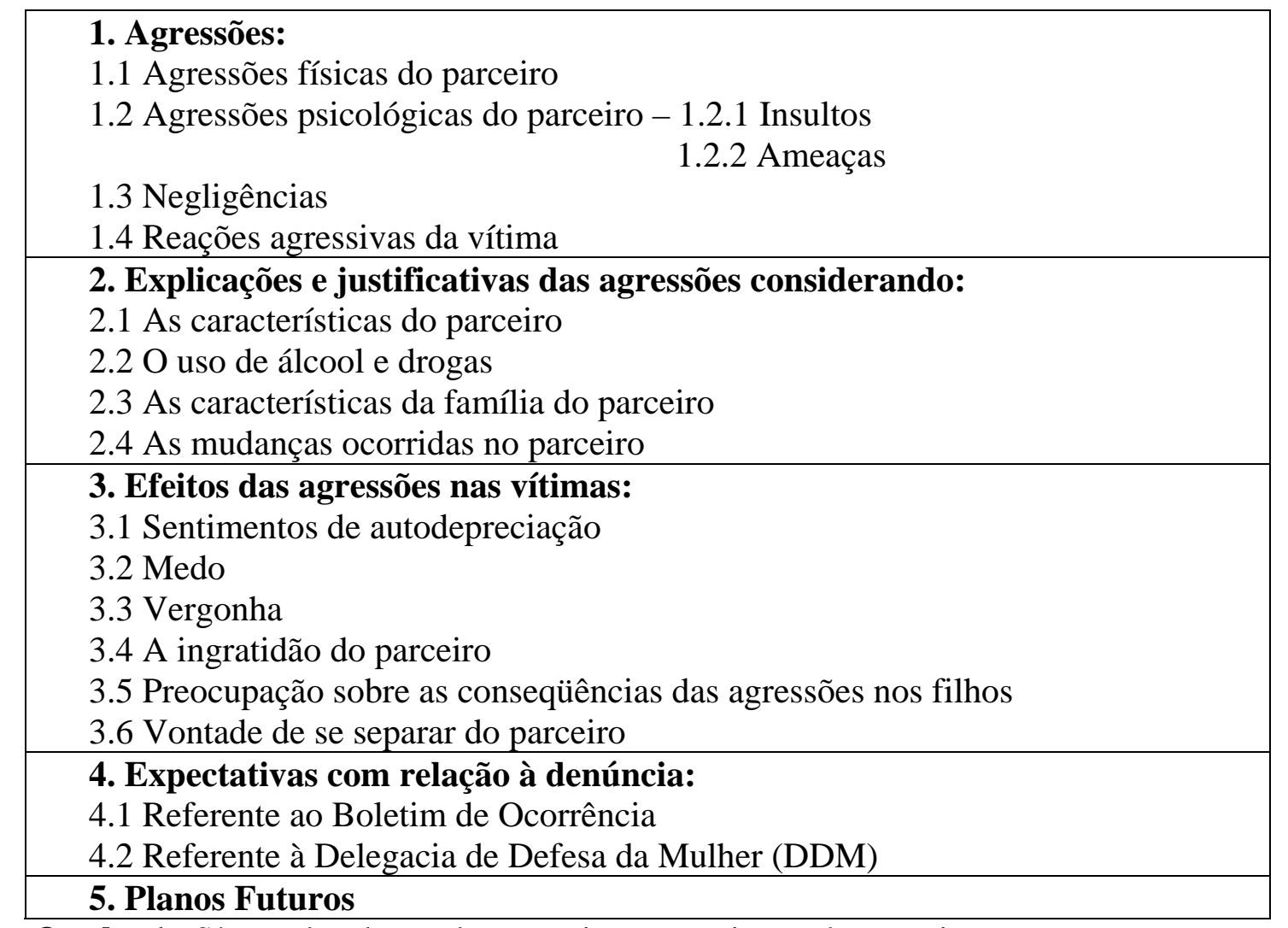

Quadro 1 - Síntese das classes de categorias, categorias e subcategorias.

Após a análise das entrevistas por meio da análise de conteúdo proposta por Bardin (1997) e Minayo (1993), chegamos às seguintes classes de categorias, categorias e subcategorias que se referem aos temas presentes nos discursos das mulheres agredidas. Cada categoria traz uma questão que se apresentou como recorrente ao longo das entrevistas ou que se destacou sob o olhar da pesquisadora. 


\section{Agressões}

Trataremos a seguir das diversas formas de agressões existentes entre homens e mulheres que foram relatadas pelas nossas entrevistadas que, inclusive, configuram o quadro de violência doméstica.

\subsection{Agressões físicas do parceiro}

A agressão física configura-se por chutes, murros, enforcamento, pancadas na cabeça, entre outros. As falas das mulheres refletem os mais variados tipos de agressões, sendo que elas as descrevem de maneira natural, como algo que faz parte de seu cotidiano.

[...] ele já catou a faca pra passar no meu rosto, pois bola de fogo no meu rosto, hoje mesmo eu to com o meu corpo todo machucado, não fui trabalhar, vou no médico de afastado porque eu não to agüentando... se você vê minha coluna tá toda machucada e inchada por causa dele. [...] (Vânia)

[..] Ele vem pra cima de mim e começa a me dar murro, me dar soco, me joga no chão, pega chave de fenda, agora dessa vez foi pior, ele pegou facão e queria me matar no meio da rua [...] (Priscila)

[...] É soco, bate minha cabeça no chão, me dá chute, me dá paulada com pau, tenta me furar com garfo, já tentou me furar com uma faca. [...] (Josi)

[...] Ele pega a gente pelo pescoço e aperta, depois que a gente começa a passar mal aí ele larga e fica chutando, batendo. [...] (Rose)

\subsection{Agressões psicológicas do parceiro}

As agressões psicológicas configuram-se por agressões verbais como ameaças e insultos, xingamentos, ofensas às capacidades pessoais e profissionais da pessoa. O isolamento da vítima, a proibição de sair de casa, de realizar atividades também é uma forma de agressão psicológica. 


\subsubsection{Insultos}

Os insultos recebidos do parceiro apresentam-se nas falas das mulheres como xingamentos direcionados a elas e aos seus familiares.

[...] ele me chama de vagabunda, me chama de vadia, eu sou casada, eu não moro junto, eu sou casada, eu sou mãe da filha dele, entendeu... [...] (Josi)

[...] ele começa a falar do meu pai: isso é culpa do seu pai e da sua mãe aqueles não sei o que e xinga de tudo quanto é nome, qualquer dia eu vou acabar com eles. [...] (Débora)

\subsubsection{Ameaças}

As falas das mulheres mostram-nos a forte presença da ameaça de morte por parte do parceiro que ameaça a vida de sua mulher com o objetivo de submetê-la e de paralisá-la por completo, para que ela não tenha nenhuma reação diante da agressão sofrida por medo de colocar sua vida em risco. Uma outra ameaça, freqüentemente, feita pelo parceiro que provoca medo na mulher é com relação aos seus filhos, da possibilidade de esses serem tirados dela.

[...] Ele fica falando que vai roubar a menina de mim pra levar embora, e ela é minha companhia. [...] (Rose)

[...] ele fica me ameaçando: se você separar de mim eu não vou te dar paz, seu pai, sua mãe, não vou dá paz pra eles, porque seis vai ta morto. [...] (Débora)

[...] se você não for ficar comigo, você não vai ficar com ninguém, sabe, aí ele quer matar, ele não aceita. [...] (Vânia)

[...] e ainda virar pra mim e falar que eu não tenho direito nenhum, que se eu for procurar a justiça ele me mata, normalmente ele fala isso, fala que se por ventura eu ganhar a metade de tudo ele quebra tudo, que ele vai pra cadeia, mas dele eu não vou tirar nada, como se eu não tivesse construído nada junto com ele. [...] (Paula)

\subsection{Negligências}

A negligência também é considerada uma forma de agressão, pois muitos parceiros deixam suas famílias sem dinheiro para comerem e se vestirem, deixando-os viver em 
condições precárias como uma forma de punição ou castigo, além de proibirem suas mulheres de saírem de casa para trabalhar.

[...] Vai lá abrir minha geladeira...não tem nada pra mim comer, porque ele tá fazendo a pirraça agora de não por nada dentro de casa. E o dinheiro que ele tem, onde ele vai ele come, porque ele tem dinheiro, ele tem da onde tirar. [...] (Priscila)

[...] quando eu fiquei desempregada e eu não tinha dinheiro pra comprar carne na quinzena do mês, porque eu comprava toda quinzena, virei pra ele e falei... você compra porque eu to sem dinheiro, ele falou tem algum ovo na geladeira? Aí eu falei tem, então nós vamos comer ovo o resto do mês ele disse. [...] (Paula)

\subsection{Reações agressivas da vítima}

É importante ressaltarmos que algumas mulheres declaram não permanecerem passivas às agressões sofridas e revidarem as do parceiro, utilizando-se também da violência.

[...] uma vez eu peguei a faca e fui pra cima dele, falei, se você me colocar a mão eu vou te matar, sabe...até eu fico com medo de mim mesma, porque eu não sei minha reação, de repente eu posso... me dá na loca, eu posso matar ele, porque eu não posso ficar apanhando desse jeito ou ele me matar, entendeu... [...] (Priscila)

\section{Explicações e justificativas das agressões}

Encontramos nos discursos das mulheres variadas explicações sobre os motivos das agressões sofridas pelos parceiros com o intuito de justificá-las e até legitimá-las.

\subsection{As características egocêntricas do parceiro}

As entrevistadas descrevem características do parceiro como sendo pessoas individualistas e egoístas, ao contrário de suas expectativas de ter ao seu lado um homem companheiro. Elas os descrevem como pessoas que só pensam nelas e que quando contrariadas as agridem. 
[...] Ele é uma pessoa que não gosta de compromissos, ele não gosta de dar satisfação...ele gosta de fazer o que bem entende, na hora que ele quiser, na hora que ele bem entender, sair... [...] (Josi)

[...] eu acho que ele quer ser solteiro, só foi comprar a moto, quer passear, sair sozinho...me cobra se tem que me levar em algum lugar quer me cobrar gasolina pra me levar, você tá entendendo, eu não tenho marido... aquela pessoa companheira. [...] (Paula)

[...] ele não respeita o seu trabalho, entendeu, não ta nem aí pra nada, só pensa nele, extremamente egoísta, egocêntrico. [...] (Débora)

\subsection{0 uso de álcool e drogas}

O uso de álcool ou drogas é comentado pelas mulheres como algo corriqueiro presente no relacionamento. Elas atribuem à agressividade do parceiro o consumo exagerado de álcool ou drogas feito por eles.

[...] quando ele vem agressivo desse jeito, não sei se ele bebeu...uma vez ele tomou umas 10 cervejas, aí ele disse: vou te bater, quero te matar, se eu não te matar eu não vou parar. [...] (Rose)

[...] Ele mexe com droga, fuma maconha, cheira cocaína... Às vezes atrapalhava um pouco, mas ele nunca misturou a droga dele com o nosso relacionamento, foi só agora mesmo.[...] (Vânia)

[...] Ele é dependente de drogas, então ele não aceita que você interfira nisso nem que peça, entendeu, ele não te escuta, e... eu resolvi entendeu que não tem jeito mesmo, ele precisa de tratamento, mas ele não quer se internar. [...] (Débora)

[...] foi de uns tempo pra cá que eu acho que ele começou a beber um pouquinho mais, aí ele se tornou uma pessoa MAIS agressiva. [...] (Priscila)

\subsection{As características da família do parceiro}

A família de origem do parceiro é um aspecto, segundo os discursos das mulheres, que justifica seu comportamento agressivo. O modo como foram criados, modelos de pais agressivos são citados pelas entrevistadas como situações desencadeadoras desse tipo de comportamento.

[...] Ele foi criado pela tia, que faz tudo por ele, tudo, tudo, tudo, até o que é errado ela protege, um dos motivos dele não criar responsabilidade, ele vive dependendo dela pra tudo. [...] (Débora) 
[...] os pais dele também separou mais ou menos na mesma época, por causa de adultério, tanto do meu lado quanto dos pais dele também, só que a diferença é que os pais dele brigavam, xingavam, se agrediam, na separação era triste. [...] (Paula)

[...] porque ele veio de uma família que via o pai bater muitas vezes na mãe e a mãe se calava com aquilo e nunca falou nada, entendeu... [...] (Priscila)

\subsection{As mudanças ocorridas no parceiro}

As falas das mulheres revelam nessa categoria uma mudança brusca e repentina no modo de ser do parceiro para com elas. Tornaram-se violentos e indiferentes ao relacionamento de uma hora para outra.

[...] ele me prometeu mil e uma coisa que no final ele mesmo não cumpriu sabe, ele era totalmente diferente. [...] (Vânia)

[...] começou recente agora que ele quer dá uma de solteiro... não bebia, era companheiro, de uma hora pra outra mudou [...] (Paula)

[...] no começo ele não era assim, ele não demonstrava ser essa pessoa [...] (Priscila)

\section{Efeitos das agressões nas vítimas}

As agressões sistemáticas geram nas mulheres vítimas uma série de efeitos que interferem no seu dia-a dia, na sua auto-estima e na sua imagem como mulher.

\subsection{Sentimentos de autodepreciação}

Essa categoria retrata a baixa auto-estima e o sentimento de desânimo com relação à vida que acomete a mulher agredida.

[...] O que ele não quis que eu fizesse eu parei de fazer. Às vezes eu não me sinto bem também, porque eu não to sendo eu mesma, porque eu não sou assim, mas porque ele quer que eu seja assim eu to sendo, pra não perder ele. [...] (Júlia)

[...] Como uma pessoa derrotada...muito derrotada...sem força pra nada, sem força pra nada mesmo. [...] (Vânia) 
Algumas retratam a angústia existente quando na presença do parceiro agressor, porém, já existe um sentimento de força e alívio na ausência dele.

[...] longe dele eu fico muito bem parece que tudo é diferente, sabe... tem mais força, mais coragem, sabe... eu não fico dependente, perto dele eu não conseguia fazer nada, ficava muito deprimida, muito desanimada, destruída, porque ele não fazia nada. [...] (Débora)

[...]To cansada de apanhar, to cansada de ser maltratada e...to cansada de ser maltratada, eu não mereço esse tipo de coisa. Depois que ele saiu de casa eu me senti como se eu tivesse renascido, como se eu tivesse começado a viver de novo. [...] (Josi)

[...] É... impressionante, a gente fica muito abalada, muito, muito, muito, tem horas que você quer assim ficar desleixada, mas eu não sou, eu sempre pensei positivo, se num der certo quem sabe eu possa arrumar outra pessoa que me dê, me dê esperança[...] (Paula)

\subsection{Medo}

O medo é um sentimento relatado com muita freqüência pela mulher agredida que é constantemente ameaçada em algo: sua vida, seus filhos, seus pais. Elas nunca sabem se o parceiro será capaz de cumprir com as ameaças que faz ou não. E há também o medo de que se elas fizerem alguma coisa que desagrade o parceiro, as agressões recomecem.

[...] Ahh... eu ficava com medo dele, sabe...eu ficava com medo dele, agora não... eu não to agüentando mais, tinha dia que eu tinha vontade de se matar, sabe, pegar e ficar andando, andando pa rua, igual ontem eu fiquei andando, andando, cheguei nove horas da noite, que eu não queria ir embora pra casa, que eu tenho um medo de eu chegar em casa e ele fazer alguma coisa comigo, entendeu... [...] (Priscila)

[...] Eu to preocupada com as minhas filhas, ne. Tenho medo que ele faça alguma coisa com elas, eu morro de medo de ele fazer alguma coisa com elas. [...] (Rose)

\subsection{Vergonha}

As falas das mulheres agredidas demonstram o sentimento de vergonha presente em suas vidas. Vergonha por serem violentadas, vergonha de ficarem com as marcas da violência 
no corpo, vergonha de assumirem a situação e denunciarem o parceiro, vergonha de permanecerem nessa relação.

[...]...então eu ficava com vergonha de ir na Delegacia, e das pessoas descobrirem... por causa da minha mãe e tudo... [...] (Josi)

[...] às vezes eu ficava marcada, eu nem saía na rua, de tanta vergonha que eu ficava, eu escondia, ía alguém me chamar lá eu não atendia, eu fingia que não tava lá. [...] (Priscila)

\subsection{A ingratidão do parceiro}

Essa categoria reflete o sentimento de ingratidão do parceiro com relação às entrevistadas. Conforme suas falas, elas se dedicam ao parceiro sem medir esforços, inclusive, vivenciam situações de privação e sofrimento que não são reconhecidas e muito menos valorizadas pelo parceiro e, além disso, esses ainda as agridem.

[...] Sei lá porque o tanto que eu ajudei, sofri tanto, cuidava dos irmão dele com febre, tinha um que era louco, ficou internado no Santa Tereza e eu tinha que cuidar dele e trabalhar, ele desinternava, eu trabalhava de dia, de noite eu ficava com ele ...e agora ele vem e faz o que...vem só pra bater na gente... [...] (Rose)

[...] por tudo o que eu fiz por ele, o tempo que ele foi preso, eu dormia em quarto de cadeia, pegava fila e chuva com minha filha, ele nunca valorizou....apanhei de polícia por causa dele. [...] (Vânia)

[...]Eu acho que ele é um puta de um ingrato, entendeu? Porque eu sempre fui boa, ele mesmo conta pra mim, pra todas as pessoas que eu sou muito boa, que eu faço tudo pra ajudar ele, que ele mesmo reconhece, ele mesmo fala isso, só que ele também não toma nenhuma atitude entendeu, ele não tem atitude, é uma pessoa totalmente sem atitude. [...] (Débora)

[...] ele foi meu primeiro homem, ele foi meu primeiro tudo, então eu sempre tive ali com ele, tanto é que eu saí da minha cidade pra vir pra cá, pra ficar com ele, entendeu. Eu passei por cima de tudo e de todos pra ficar com ele, pra agora ele estar me agradecendo dessa forma. [...] (Paula)

\subsection{Preocupações sobre as conseqüências das agressões nos filhos}

Existe uma preocupação das mulheres agredidas com as conseqüências dos episódios de violência entre elas e seus respectivos maridos que são presenciados por seus filhos ainda crianças. Elas acreditam que seus filhos estão traumatizados pelo comportamento 
agressivo do parceiro e, inclusive, comentam sobre alguns problemas de comportamento que as crianças estão apresentando.

[...] Minhas filhas vê ele sempre me batendo na frente delas...elas tão mais traumatizadas di que eu. [...] (Rose)

[...] não tenho paciência com minha filha, se você perguntar, minha filha fala tudo o que aconteceu, aí onde eu fico mais dolorida, sabe. [...] (Vânia)

[...] ele já ta causando um trauma nas crianças, elas tão com medo dele e ele não enxerga isso, ele fala que é eu e minha família que faz pressão pras crianças não querer chegar perto dele... [...] (Débora)

[...] ela tá sendo criada desse jeito, ela é toda nervosa, ela bate na cabeça dela, ela arranca cabelo, agora deu de comer, o dia que nós levamos ela no pediatra, o pediatra falou, nossa não era pra ela tá assim não, você tem costume de discutir com seu marido perto dela? Aí eu comecei a chorar e contei pra pediatra... [...] (Priscila)

\subsection{Vontade de se separar do parceiro}

O discurso das entrevistadas demonstra a vontade de se separar do parceiro, alegam estarem cansadas de seu comportamento violento e dizem sobre como se sentem bem na ausência desses. Porém, muitas não tomam nenhuma atitude para que a separação aconteça, e inclusive, têm medo de falar disso com o parceiro.

[...] Nunca mais eu quero ficar com ele, espero que ele não perturbe na casa que eu to morando. [...] (Rose)

[...] desde que ele saiu eu to triste, mas eu to me sentindo aliviada, mas eu amo ele, entendeu, apesar de tudo, mas eu não quero mais, porque eu tenho que aprender a me amar primeiro, porque ele não me ama, se ele me amasse ele não me maltrataria tanto desse jeito. A gente não bate em quem ama. Se ele não me ama, pra que eu vou amar ele? [...] (Josi)

[...] eu falei, eu não quero ficar com você assim, não tenho condições mais, falei eu posso até matar minha mãe e meu pai de desgosto, entendeu... eu não quero mais ficar desse jeito, eu cansei, to cansada, não posso ficar igual sua mãe assim, com 53 anos apanhando nas costas e agüentando calada. [...] (Priscila) 


\section{Expectativas com relação à denúncia}

A denúncia realizada pela mulher numa Instituição Policial é o primeiro passo para que ela quebre o ciclo da violência doméstica, rompendo com o silêncio. Buscamos, nas categorias seguintes, agrupar as expectativas dessas mulheres agredidas com relação à Instituição e aos seus procedimentos de trabalho.

\subsection{Referente ao Boletim de Ocorrência}

O Boletim de Ocorrência é significado pelas mulheres agredidas como uma solução para seus problemas com o comportamento agressivo dos maridos e ao mesmo tempo é desacreditado por algumas delas na sua eficiência penal na resolução de casos referente à violência doméstica. Porém, o Boletim de Ocorrência é como se fosse a última tentativa de se defender do parceiro agressor, pois ele é, geralmente, realizado pela vítima após vários episódios de agressões contra a mesma.

[...] Eu to cansada de apanhar porque ele não aceita a separação, aí eu peguei e comecei a dar queixa dele, é a única maneira de eu conseguir ficar livre disso. [...] (Vânia)

[...] Eu espero que ele seja chamado, eu espero que ele... porque eu acho assim, se eu não viesse agora ía acontecer outras vezes, eu acho que vindo agora, fazendo o boletim, ele vai responder, ele vai ter medo de me bater de novo, porque ele sabe que se ele me bater de novo, ele vai ter conseqüências, entendeu, não vai ficar de graça. [...] (Josi)

[...] Bom, eu sei que virar alguma coisa acaba não virando nada sabe, mas pelo menos é um respaldo legal que eu vou ter dentro da minha separação pro juiz, pelo menos se o juiz enxergá que eu to tentando proteger os meus filhos de uma pessoa que não merece viver em sociedade, não tem condições de viver em sociedade. [...] (Débora)

[...] Ah então... chegou a intimação pra ele, ele não veio na intimação, ele recebeu e falou que não tem medo dessas coisas, aí eu falei assim, ai... não vai virar nada porque isso é demorado.[...](Priscila)

Interessante notar também que a maioria das mulheres que recorrem ao Boletim de Ocorrência não vai ao Fórum representar sua queixa, portanto, não dá continuidade ao processo. 
[...] vim fazer um boletim, só que eu também não fiz mais nada, só fiz um boletim e a delegada me aconselhou, olha se você quiser dar continuidade vai ter que ir no fórum,entrar num processo...num fiz, só fiz o boletim, mas depois acabei contando pra ele que era pra ele se sentir ameaçado e não tocar mais em mim, não adiantou ele continuou tocando em mim, que foi o que aconteceu agora. [...] (Júlia)

\subsection{Referente à Delegacia de Defesa da Mulher (DDM)}

Essa categoria agrupa falas das mulheres entrevistadas que representam a DDM como mediadora de seus conflitos conjugais. A DDM é descrita por elas como um local de proteção e acolhimento às vítimas, mas que, no entanto, não é levada a sério pelos parceiros.

[...] eu me senti tão... desprotegida, que eu falei AHH preciso de proteção, aí pensei cá comigo, a Delegacia é uma proteção pra mim. [...] (Júlia)

[...] Porque é mais fácil você vim numa delegacia das mulheres e conversar com uma delegada e conversar com uma escrivã, uma mulher, porque você consegue ter mais intimidade com uma mulher, do que você chegar e... uma vez eu já fui, só que o escrivão me tratou tão mal, sabe... que aí eu desisti e não fiz mais. [...] (Josi)

[...] Eu espero...ou ele vai preso porque assim eu não vou ter uma paz, porque ele falou que se chamar ele na Delegacia ele vem, mas se ele ver eu na rua ele vai fazer a mesma coisa, porque ele não tem medo de polícia, e realmente ele não tem medo de ninguém. [...] (Vânia)

\section{Planos Futuros}

As mulheres agredidas possuem projetos de vida, sonhos e esperanças para seu futuro.

Trabalhar, cuidar dos filhos, libertar-se do parceiro são alguns de seus planos que na visão delas lhes propiciaria uma vida mais tranqüila.

[...] Faculdade não tenho como pagar, mas um curso que eu posso pagar... quero casar no papel direitinho, ter uma família que eu não tive exatamente, não tive com meus pais, meus irmãos... [...] (Júlia)

[...] Agora eu quero trabalhar, erguer a cabeça, trabalhar e cuidar delas, né, nós não pedimos pra acontecer tudo isso, agora então tenho que trabalhar pra tocar, né. [...] (Rose)

[...] Agora eu quero trabalhar, cuidar da minha filha, tocar minha vida pra frente, sabe...melhorar, sair um pouco dessa depressão. Quero voltar a passear, fazer o que eu fazia antes com a minha filha, vestir ela, porque ele não me ajudava com nada... só quero tocar minha vida pra frente, esperar ele dá uma paz um pouco pra mim, pra mim continuar, porque senão, agora de imediato não dá. [...] (Vânia) 
[...] ele tem que se ...tem que acontecer alguma coisa com ele, entendeu, porque se ficar do jeito que tá ele mesmo já falou que não vai me dar paz, não vai dar paz pra minha família [...] (Débora)

[...] eu tenho planos, planos pra minha vida, planos de verdade, de voltar pra minha cidade, estudar, trabalhar, lá eu tenho certeza que onde eu deixar minha filha ela vai ser bem cuidada, bem tratada, na casa da minha mãe, na casa da minha tia. [...] (Josi)

[...] Eu... assim... se por ventura nós separar tudo eu vou voltar pra minha cidade porque aqui eu não fico, mesmo porque se eu ficasse aqui ele ía mandar alguém me matar, coisa assim sabe, e::.:... eu quero voltar pra lá e começar uma nova vida porque aqui não dá pra continuar...e é isso aí. Graças à Deus eu nunca dependi dele, nunca me deu uma calcinha como se diz, ele nunca deixou eu pegar um real da carteira dele...nunca...toda vida... [...] (Paula)

[...] Aí...eu penso em largar dele e tomar um rumo na vida entendeu...Dá minha menina pra minha mãe criar, arrumar serviço e viver a minha vida, porque eu acho que ele não vai melhorar... do jeito que ele tá a tendência é piorar...(Priscila)

Tabela 1 - Síntese dos principais aspectos apresentados na entrevista

\begin{tabular}{|c|c|c|c|c|c|c|c|}
\hline Nome* & Vânia & Josi & Júlia & Rose & Débora & Paula & Priscila \\
\hline Idade & 22 anos & 27 anos & 21 anos & 35 anos & 31 anos & 26 anos & 25 anos \\
\hline Filhos & $\begin{array}{l}1 \text { filha de } \\
3 \text { anos }\end{array}$ & $\begin{array}{l}\text { Não tem } \\
\text { filhos }\end{array}$ & $\begin{array}{l}\text { Não tem } \\
\text { filhos }\end{array}$ & $\begin{array}{l}2 \text { filhas: } 9 \\
\text { anos e } 3 \\
\text { anos }\end{array}$ & $\begin{array}{l}1 \text { filho de } \\
8 \text { anos e } 1 \\
\text { filha de } 5 \\
\text { anos }\end{array}$ & $\begin{array}{l}\text { Não tem } \\
\text { filhos }\end{array}$ & $\begin{array}{lr}1 & \text { filha } \\
\text { de } & 1 \\
\text { anos e } & 5 \\
\text { meses }\end{array}$ \\
\hline $\begin{array}{c}\text { Escolari- } \\
\text { dade }\end{array}$ & $\begin{array}{l}\text { Ensino } \\
\text { Médio } \\
\text { incomple- } \\
\text { to }\end{array}$ & $\begin{array}{l}\text { Ensino } \\
\text { Médio } \\
\text { completo }\end{array}$ & $\begin{array}{l}\text { Ensino } \\
\text { Médio } \\
\text { completo }\end{array}$ & $\begin{array}{l}\text { Ensino } \\
\text { Médio } \\
\text { incomple- } \\
\text { to }\end{array}$ & $\begin{array}{l}\text { Ensino } \\
\text { Médio } \\
\text { incomple- } \\
\text { to }\end{array}$ & $\begin{array}{l}\text { Ensino } \\
\text { Médio } \\
\text { completo }\end{array}$ & $\begin{array}{l}\text { Ensino } \\
\text { Médio } \\
\text { incom- } \\
\text { pleto }\end{array}$ \\
\hline Emprego & $\begin{array}{l}\text { Balconis- } \\
\text { ta de } \\
\text { padaria }\end{array}$ & $\begin{array}{l}\text { Desem- } \\
\text { pregada }\end{array}$ & $\begin{array}{l}\text { Desem- } \\
\text { pregada }\end{array}$ & $\begin{array}{l}\text { Cozinhei- } \\
\text { ra de res- } \\
\text { taurante }\end{array}$ & $\begin{array}{l}\text { Funcioná- } \\
\text { ria da Pre- } \\
\text { feitura } \\
\text { (contrata- } \\
\text { da) }\end{array}$ & 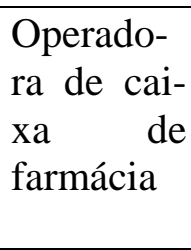 & $\begin{array}{l}\text { Desem- } \\
\text { pregada }\end{array}$ \\
\hline $\begin{array}{c}\text { Tempo } \\
\text { com o } \\
\text { parceiro } \\
\text { atual } \\
\end{array}$ & 6 anos & 4 anos & 6 anos & $\begin{array}{l}7 \text { anos }\left(2^{\circ}\right. \\
\text { casamen- } \\
\text { to) }\end{array}$ & 8 anos & 9 anos & 7 anos \\
\hline $\begin{array}{c}\text { Agressõe } \\
\text { s de } \\
\text { outros } \\
\text { parceiro } \\
\text { s }\end{array}$ & $\begin{array}{l}1^{\mathrm{a}} \text { vez que } \\
\text { é agredida }\end{array}$ & $\begin{array}{l}1^{\mathrm{a}} \text { vez que } \\
\text { é agredida }\end{array}$ & $\begin{array}{l}1^{\mathrm{a}} \text { vez que } \\
\text { é agredida }\end{array}$ & $\begin{array}{l}2^{\mathrm{a}} \text { vez que } \\
\text { é agre- } \\
\text { dida. } \\
1^{\mathrm{a}} \text { vez foi } \\
\text { seu ex- } \\
\text { marido } \\
\end{array}$ & $\begin{array}{l}1^{\mathrm{a}} \text { vez que } \\
\text { é agredida }\end{array}$ & $\begin{array}{l}1^{\mathrm{a}} \text { vez que } \\
\text { é agredida }\end{array}$ & $\begin{array}{l}1^{\mathrm{a}} \text { vez } \\
\text { que } \\
\text { é } \\
\text { agredida }\end{array}$ \\
\hline $\begin{array}{c}\text { Pais } \\
\text { agressi- } \\
\text { vos }\end{array}$ & não & não & não & $\operatorname{sim}$ & não & não & não \\
\hline
\end{tabular}




\begin{tabular}{|c|c|c|c|c|c|c|c|}
\hline Nome* & Vânia & Josi & Júlia & Rose & Débora & Paula & Priscila \\
\hline $\begin{array}{c}\text { Parceiro } \\
\text { com pais } \\
\text { agressi- } \\
\text { vos }\end{array}$ & não & não & não & não & não & $\operatorname{sim}$ & $\operatorname{sim}$ \\
\hline $\begin{array}{l}\text { Parceiro } \\
\text { usa } \\
\text { álcool ou } \\
\text { drogas }\end{array}$ & drogas & não & álcool & álcool & drogas & álcool & álcool \\
\hline Traição & $\operatorname{sim}$ & não & não & não & não & $\operatorname{sim}$ & $\operatorname{sim}$ \\
\hline $\begin{array}{c}\text { Separa- } \\
\text { ção }\end{array}$ & $\begin{array}{l}\text { Decidiu } \\
\text { pela } \\
\text { separação }\end{array}$ & $\begin{array}{l}\text { Parceiro } \\
\text { saiu de } \\
\text { casa }\end{array}$ & $\begin{array}{l}\text { Não quer } \\
\text { se separar }\end{array}$ & $\begin{array}{l}\text { Foi } \\
\text { expulsa } \\
\text { de casa } \\
\text { pelo } \\
\text { parceiro }\end{array}$ & $\begin{array}{l}\text { Separou e } \\
\text { voltou }\end{array}$ & $\begin{array}{l}\text { Pensa em } \\
\text { se separar }\end{array}$ & $\begin{array}{l}\text { Não } \\
\text { sabe o } \\
\text { que quer } \\
\text { fazer }\end{array}$ \\
\hline $\begin{array}{l}\text { Motivos } \\
\text { para o } \\
\text { início } \\
\text { das } \\
\text { agressõ- } \\
\text { es }\end{array}$ & $\begin{array}{l}\text { O } \\
\text { parceiro } \\
\text { não aceita } \\
\text { a } \\
\text { separação }\end{array}$ & $\begin{array}{l}\text { Qualquer } \\
\text { coisa, } \\
\text { qualquer } \\
\text { motivo } \\
\text { "bobo". }\end{array}$ & ciúmes & $\begin{array}{l}\text { A família } \\
\text { do parcei- } \\
\text { ro não } \\
\text { gosta dela } \\
\text { por ser } \\
\text { branca }\end{array}$ & $\begin{array}{l}\text { Desprezo } \\
\text { dela pelo } \\
\text { parceiro }\end{array}$ & $\begin{array}{l}\text { Comprou } \\
\text { uma moto } \\
\text { e come- } \\
\text { çou a dar } \\
\text { uma de } \\
\text { solteiro }\end{array}$ & $\begin{array}{l}\text { Desco- } \\
\text { briu que } \\
\text { o } \\
\text { parceiro } \\
\text { tinha } \\
\text { uma } \\
\text { amante }\end{array}$ \\
\hline $\begin{array}{l}\text { Planos } \\
\text { futuros }\end{array}$ & $\begin{array}{l}\text { Trabalhar, } \\
\text { cuidar da } \\
\text { filha e } \\
\text { esperar o } \\
\text { parceiro } \\
\text { dar um } \\
\text { pouco de } \\
\text { paz para } \\
\text { ela. }\end{array}$ & $\begin{array}{l}\text { Voltar } \\
\text { para sua } \\
\text { cidade, } \\
\text { estudar e } \\
\text { trabalhar. }\end{array}$ & $\begin{array}{l}\text { Casar no } \\
\text { papel, } \\
\text { construir } \\
\text { uma } \\
\text { família. }\end{array}$ & $\begin{array}{l}\text { Trabalhar } \\
\text { e cuidar } \\
\text { das filhas. }\end{array}$ & $\begin{array}{l}\text { Esperar } \\
\text { acontecer } \\
\text { alguma } \\
\text { coisa com } \\
\text { o parcei- } \\
\text { ro, pois } \\
\text { ele não } \\
\text { lhe dará } \\
\text { paz. }\end{array}$ & $\begin{array}{l}\text { Voltar } \\
\text { para sua } \\
\text { cidade. }\end{array}$ & $\begin{array}{l}\text { Não } \\
\text { sabe, sua } \\
\text { mãe fala } \\
\text { para ela } \\
\text { largar o } \\
\text { parceiro } \\
\text { e dar a } \\
\text { filha } \\
\text { para ela } \\
\text { criar } \\
\text { para po- } \\
\text { der arru- } \\
\text { mar um } \\
\text { emprego }\end{array}$ \\
\hline
\end{tabular}

* Os nomes utilizados para a discriminação das participantes da pesquisa são fictícios.

Para podermos entender os aspectos destacados na tabela acima os quais foram considerados os temas principais dos discursos das entrevistadas, segue uma breve descrição explicativa da mesma. 
O menor tempo de união com o atual parceiro é de Josi, de quatro anos, e o tempo máximo é de Paula, de nove anos. Elas foram morar com o parceiro após uma média de seis meses de namoro, com exceção de Débora e Paula que namoraram um ano meio. Paula tinha catorze para quinze anos quando "amasiou” com seu parceiro. Vânia e Priscila saíram de casa sem a aprovação de seus pais.

Nenhuma delas cursa ou cursou faculdade, três delas possuem o Ensino Médio completo e quatro possuem o Ensino Médio incompleto. Quatro delas estão empregadas, porém, com piso salarial baixo, de no máximo um salário mínimo e meio, sendo que Josi, Júlia e Priscila estão desempregadas.

As participantes relatam ter sido a primeira vez em que são agredidas por um parceiro, com exceção de Rose que foi agredida pelo seu ex-marido com quem foi casada durante seis anos.

Rose é a única entrevistada que relata ter o pai agressivo. Ela vivenciou inúmeras cenas de violência dentro de casa em que seu pai batia em sua mãe e nos filhos. As demais mulheres afirmam que seus pais são tranqüilos, que nunca as agrediram e que dificilmente presenciaram discussões deles na frente dos filhos. Vânia comenta que a única vez que seu pai lhe agrediu foi devido ao seu atual parceiro. Com relação aos pais de seus companheiros, Paula e Priscila comentam que seus parceiros “cresceram vendo o pai bater na mãe”.

O uso de drogas e álcool pelo parceiro é uma constante no relacionamento das mulheres entrevistadas, com exceção de Josi que afirma que seu parceiro “não possui nenhum vício”. Vânia sabia desde o início de seu relacionamento sobre o uso de drogas feito pelo parceiro, Débora descobriu logo após se casar. As demais mulheres relatam que houve um aumento do consumo de álcool, no decorrer dos anos do relacionamento.

Conforme o relato das entrevistadas, houve traição pelo parceiro nos relacionamentos de Vânia, Paula e Priscila e no caso de Vânia não foi apenas uma vez. 
A separação é uma decisão que todas dizem querer tomar, com exceção de Júlia que deseja "casar e construir uma família” com o parceiro agressor. Vânia saiu de casa um mês antes da entrevista e diz ter sido esse fato que motivou o parceiro a agredi-la. O parceiro de Josi saiu de casa alguns dias antes da entrevista, mas nada foi resolvido ainda entre eles. Rose foi expulsa de casa pelo parceiro, levou suas filhas consigo e está morando na casa de uma amiga, saiu de casa sem pegar nenhum objeto seu e nem das crianças. Débora separou-se e voltou com o parceiro, após ele ter se convertido religiosamente. Paula decidiu separar-se do marido, mas ainda não tomou nenhuma providência com relação a isso e Priscila não sabe o que deseja fazer, apesar da mãe e suas amigas dizerem para se separar do parceiro.

Os motivos que propiciaram o início das agressões descritas pelas mulheres são variados como: ciúmes do parceiro com sua mulher, pedido de separação da mulher, não-aceitação da mudança de comportamento do parceiro e não-aceitação da traição do parceiro.

Os planos futuros dessas mulheres em geral são: estudar, trabalhar e cuidar dos filhos. Josi e Paula pretendem voltar para sua cidade natal. Júlia pretende casar com o parceiro atual “no papel”. Vânia e Débora esperam que o parceiro decida dar paz para elas. Rose quer continuar trabalhando para cuidar de suas filhas, e Priscila ainda tem dúvidas sobre o que deseja para si. 


\section{DISCUSSÃO}

Podemos perceber nos dados que emergiram da análise de conteúdo que as mulheres entrevistadas percebem o relacionamento homem e mulher como o desempenho dos papéis estereotipados e idealizados pela sociedade ao longo dos anos e que ainda permeiam nossa cultura atual como o de homem forte e mulher submissa. Papéis esses construídos sobre crenças e valores morais, religiosos e políticos devidamente cultivados pelos cidadãos de cada época como foi descrito na introdução desta pesquisa. Porém, a mulher do século XXI está cercada por grandes mudanças socioculturais que dizem respeito a sua conduta na sociedade, principalmente, nos quesitos econômicos e políticos. Isso traz mudanças em seus relacionamentos sociais e o casamento é uma instituição que está se reestruturando com relação à efetiva participação feminina e masculina. Essa reestruturação de papéis influencia na participação econômica dentro de casa, de ambos os parceiros, no relacionamento sexual, na educação dos filhos, e também, na violência doméstica.

A presente pesquisa verificou um perfil das participantes que, inclusive, coincidiu em alguns aspectos com dados de pesquisas da revisão da literatura. O perfil encontrado descreve questões como: as uniões afetivas das mulheres agredidas com o parceiro agressor têm uma média de sete anos de convivência, a faixa etária das entrevistadas é de 21 a 35 anos de idade, quatro delas não terminaram o Ensino Médio e três terminaram, porém não continuaram os estudos. A renda familiar é baixa, pois as mulheres possuem empregos operacionais e com baixa remuneração, geralmente, de um salário mínimo apenas, trabalhando como balconista de padaria e operadora de caixa, por exemplo, sendo que quatro delas se encontram desempregadas e dependem de seus companheiros que, na maioria das vezes, também possuem empregos com baixa remuneração para se sustentarem. Adeodato (2005), Heise, Ellsberg e Gottemoeller (1999) observaram que quanto menor a renda, maior a ocorrência de 
agressão verbal, física e sexual entre o casal. Porém, devemos levar em consideração que, conforme já mencionado, as mulheres pertencentes à classe social baixa são as que denunciam a agressão na Delegacia, ao contrário do que ocorre com as mulheres da classe social alta que recorrem a atendimentos particulares para lidar com a situação (SILVA, 1992).

Ainda sobre o perfil, podemos dizer que as entrevistadas são mulheres jovens, começando a construir uma família, quatro delas têm filhos pequenos, na faixa de um ano e meio a nove anos de idade e três delas ainda não têm filhos. Segundo Adeodato (2005) na sua pesquisa sobre a presença de depressão na mulher vitimizada, o perfil encontrado da mulher agredida que registrou queixa na Delegacia da Mulher é: jovem, casada, católica, tem filhos, pouco tempo de estudo e baixa renda familiar. Além disso, apresenta um tempo conjugal com o agressor em torno de dez anos, e um tempo de agressão (que se refere ao período em anos no qual a mulher vem sofrendo as agressões do parceiro) de aproximadamente cinco anos. De acordo com Browne (1983), a média de uma relação abusiva dura cerca de seis anos - a mesma média de tempo do casamento. Podemos também levantar uma questão referente ao tempo de união, por esperarmos ser no início da vida conjugal, o momento em que ocorre a denúncia, a vontade de se separar, pois com o tempo os casais tendem a se ajustar de forma que não necessitem mais recorrer à violência ou esta, se ainda existir, já teria sido adaptada de alguma forma na relação.

Nossas entrevistadas relatam terem sofrido agressões verbais e físicas, sendo interessante notar que nenhuma delas citou a presença da violência sexual em seu relacionamento abusivo com o parceiro, porém, conforme Barnett (2000), a violência física, geralmente, é acompanhada da violência sexual. Segundo a autora, acontece de a mulher esconder tal ato para que a sociedade não a estigmatize e para não ficar desmoralizada publicamente. Fica, então, uma questão sobre se as mulheres entrevistadas sofrem abusos 
sexuais de seus parceiros e não quiseram falar sobre isso pelos motivos citados acima ou se, simplesmente, elas não sofrem esse tipo abuso.

Sobre as percepções de violência, as entrevistadas demonstram acreditarem que são responsáveis pelo relacionamento assim como pelas agressões sofridas, que os parceiros as agridem por algo que elas fizeram ou que deixaram de fazer e eles não gostaram. No dia da entrevista em que elas estavam prestando queixa contra o parceiro, relataram não ser a primeira vez que sofrem agressões deles. Elas demonstram excessiva dependência emocional e financeira do parceiro, além da preocupação com o futuro dos filhos, fato esse muito presente também nas observações dos atendimentos do GEAVIDAS, em que as mulheres declararam que não quiseram se separar ainda do marido por causa dos filhos. Outro aspecto importante, notado durante as observações a campo e no discurso das mulheres entrevistadas, foi a dificuldade de comunicação que os casais demonstram ter, necessitando sempre de um terceiro como pais, irmãos, vizinhos e, inclusive, a Instituição para resolver seus problemas. Segundo May (1972 apud NEVES, 2004), a incapacidade de comunicar-se denuncia a deterioração dos vínculos entre as pessoas. Percebíamos, nos atendimentos realizados na DDM, que os casais não sabiam comunicar-se de maneira clara e solidária, daí as agressões. Isso nos sugere certa falência dos modelos de interação entre as pessoas na sociedade contemporânea, que pode ser analisado, inclusive, pelo crescente índice de violência doméstica na comunidade.

As entrevistadas mantêm a esperança de que eles irão melhorar como marido e que, assim, deixarão de ser violentos. Porém, reclamam insistentemente sobre a postura do parceiro de indiferença e egoísmo com relação a elas, afirmando categoricamente sobre uma abrupta mudança no comportamento do parceiro que antes era gentil e carinhoso e agora é um agressor. Fato esse que nos chama muito a atenção, pois há relatos sobre o início do relacionamento que já demonstravam uma postura agressiva do parceiro e nos questionamos 
se as entrevistadas haviam notado isso ou se, realmente, as pequenas agressões da época do namoro passavam-lhes despercebidas. Há também casos de parentes da própria vítima identificar o parceiro como agressor muito antes da entrevistada. Como por exemplo, o pai de Priscila que já enxergava o comportamento violento do parceiro de sua filha.

[...] no começo assim... quando eu levei ele, meu pai falava assim, ele não é um bom moço pra você, a cara dele num nega, ele ta fazendo essa cara de bonzinho até levar você embora porque esse cara, ele tem jeito de quem bate em mulher, ele ta fazendo essa cara de santinho, mas ele não me engana, esse rapaz não me engana.. [...] (Priscila)

[...] meu pai dizia, você vai se arrepender, você vai chorar amargamente, esse cara tem cara de quem vai judiar de você [...] (Priscila)

No caso de Júlia, o parceiro na época do namoro já demonstrava notável agressividade:

[...] eu já tava vendo que ele tava se alterando, no que minha mãe foi tentar separar, minha mãe entrou no meio pra separar, ele empurrou ela [...] Júlia

Porém, podemos pensar também sobre a dificuldade que temos em admitir quando erramos, que escolhemos o parceiro errado, por exemplo. Assim, quando as entrevistadas acreditam que o parceiro possa se modificar e que se trata apenas de um problema passageiro, de mau comportamento dele, que pode ser corrigido, acreditamos que elas estão, dessa forma, justificando e até salvaguardando suas escolhas.

As entrevistadas percebem seu papel de mulher como aquela que deve fazer tudo para que o relacionamento dê certo e para agradar o marido, inclusive perdoar agressões e traições. E percebem o papel do homem como a figura central do relacionamento, que decide sobre o que deve e o que não deve ser feito na relação a dois. Segundo Barnett (2000), as mulheres agredidas sacrificam-se significativamente mais do que as que não sofrem abuso. Para a autora, trata-se de um mito de martírio e masoquismo que foi erroneamente aprendido ao longo de sua socialização. Interessante ressaltarmos que espontaneamente, sem nenhuma 
pergunta direcionada do nosso roteiro, todas as entrevistadas trouxeram o tema do sacrifício delas em prol do parceiro e sua indignação pela ingratidão dele, que ao contrário de serem gratos pelo seu martírio, as agridem.

[...] eu e minha filha debaixo de chuva, visitando, agüentando humilhação de cadeia, às vezes eu tirava da minha boca pra levar pra ele, sabe... e aí hoje eu levei isso daí por ele...essa desavença...[...] (Vânia)

As conseqüências das agressões físicas e verbais sistemáticas nas mulheres são inúmeras, como já dito anteriormente, assim, nós, profissionais da saúde, devemos ficar atentos com relação a sua baixa auto-estima e sentimentos de desânimo com relação à vida, o que pode, inclusive, caracterizar um quadro depressivo. As mulheres entrevistadas relatam sentimentos de autodepreciação e de desânimo com relação à vida. Uma revisão de evidências empíricas afirma que as agressões psicológicas aumentam os quadros depressivos, diminuem a auto-estima e, geralmente, precedem a agressão física (BARNETT, 2000).

As elevadas pontuações encontradas na pesquisa de Adeodato (2005), no questionário Beck, condizem com o estudo de Mullen et al. (1988) que afirma que depressão, ansiedade e sintomas fóbicos caracterizam as síndromes clínicas encontradas em mulheres agredidas. Um outro trabalho, realizado com 117 mulheres na cidade de Campinas, no Estado de São Paulo, por Cabral et al. (2002), também mostrou que as mulheres que são vítimas de violência conjugal exprimem sentimentos de solidão, tristeza crônica, desamparo, irritação e descrença.

Conforme Campbell (1989), Russell (1989), Walker (1979), a baixa auto-estima é um precursor do abuso. Pesquisas encontraram algumas diferenças na auto-estima entre mulheres agredidas e não agredidas (CAMPBELL, 1989; RUSSELL, 1989). E como conseqüência das agressões a auto-estima tende a diminuir, o que acaba sendo o resultado da agressão e também uma de suas causas (RUSSEL,1997). 
Mulheres que sofrem violência têm quatro vezes mais probabilidade de apresentar depressão, doenças psicossomáticas e ideações suicidas que mulheres não agredidas (BARNETT, 2000).

Um fato que nos chamou a atenção no discurso das mulheres foram as explicações referentes à família do agressor para justificar a agressividade do parceiro, como por exemplo, a forma como ele foi criado. Conforme Barnett (2000), a mulher agredida sente necessidade de explicar os motivos da violência que sofre. Algumas justificativas comuns são: que quando houve a agressão “parecia que não era ele”, “ele foi abusado quando criança”, “cresceu vendo o pai bater na mãe”, “está desempregado”, “é só quando ele bebe”. Acreditamos que esse comportamento dificulta que as mulheres agredidas enxerguem a realidade de seu relacionamento e a maneira não saudável de convivência com o parceiro que também necessita de ajuda assim como ela.

Um outro aspecto utilizado pelas mulheres para explicar as agressões sofridas é o uso de álcool e drogas pelo parceiro, que no caso das nossas entrevistadas, somente o parceiro de Josi não tem nenhum vício. A relação do álcool ou das drogas como precursores da violência doméstica é um assunto polêmico entre os pesquisadores. Acreditamos que isso acontece devido à dificuldade de estabelecer uma relação de causa e conseqüência entre o álcool, as drogas e a agressão.

De acordo com Brookoff (1997), uma pesquisa, sobre abusos de esposas em Memphis, verificou que 92\% dos maridos tinham feito uso de álcool ou drogas no dia do abuso.

Neves (2004), em seu estudo sobre a violência física de pais e mães contra filhos, indica o uso de álcool como elemento de queixa das famílias entrevistadas, sendo apontado como o maior causador de crises e espancamentos contras as mulheres das gerações de avós e mães. 
Segundo Bennett (1994), para um alcoólatra, ficar bêbado é o seu objetivo, para um agressor violentar é seu objetivo. Segundo o autor, pesquisas não apóiam a idéia de que os agressores quando alcoolizados estão totalmente fora de controle a ponto de não pensarem no que estão fazendo ou que a droga ou álcool acarretam uma desinibição que promove a agressão.

Entre as conseqüências das agressões nas vítimas, o sentimento de medo é a reação mais comum da mulher que sofre agressão, especificamente, o medo da vingança que é a segunda razão mais freqüente do por que as mulheres permanecem nos relacionamentos abusivos (BARNETT, 2000).

A fim de pensarmos nos motivos que fazem com que as mulheres agredidas permaneçam com seus parceiros agressores, é importante descrevermos a teoria do ciclo da violência doméstica proposta por Walker (1979). Essa violência sofrida pelas mulheres segue, muitas vezes, por um ciclo de três fases que descreve uma seqüência de comportamentos típicos dos relacionamentos abusivos: a) fase em que menores incidentes violentos podem acontecer durante momentos de raiva; b) fase em que severos atos violentos ocorrem; c) fase da lua-de-mel em que o agressor adula sua mulher.

Na primeira fase, ocorre a formação de tensão que é expressa através da violência psicológica, simbólica ou emocional. Nesse período, a mulher tenta acalmar o agressor mostrando-se dócil, prestativa, agradando-o, pois acredita que pode impedir a raiva. Ela sentese responsável pelos atos do parceiro e pensa que, ao fazer algumas coisas que são consideradas corretas, pode terminar com esse incidente. Nesse sentido, ela assume a culpa e busca justificativas para tal ato, como o parceiro está cansado, está bebendo demais, etc. (WALKER, 1979).

A segunda fase é a da explosão da tensão ou de incidente de espancamento grave (violência física), no qual ocorre o descontrole e a destruição. Nessa fase já ocorre a violência 
física, tornando a relação insustentável. Geralmente, algumas mulheres percebem a chegada dessa fase e acabam provocando incidentes violentos por não suportarem tal situação. Essa fase é mais curta e será seguida pela terceira fase, da lua-de-mel (WALKER, 1979).

A terceira fase é conhecida como a da lua-de-mel no qual ocorre o arrependimento do agressor. Em razão do remorso, ele pede perdão, demonstra-se culpado e jura efusivamente que não irá mais agir de forma violenta. Nessa fase a mulher percebe sua importância para o parceiro e é reconhecida como boa esposa, então ela se recupera das agressões e se lembra de que elas não são as únicas coisas de seu relacionamento, que há também bons momentos. Com isso, ela reconhece que ama o agressor e que se preocupa com ele, com seus sentimentos, com sua saúde se ela o deixar, com sua reputação e também se preocupa com o relacionamento dele e de seus filhos e o restante da família, ou seja, ela se preocupa com a vida do agressor em geral. De fato, se ela já o deixou, possivelmente, retornará devido ao sentimento de amor que nutre por ele (WALKER, 1979).

Para muitas mulheres, a fase da lua-de-mel promove razões para que ela tenha esperanças de que seu parceiro irá mudar o seu comportamento agressivo ou sua personalidade. Barnett (2000) descobriu que a espera que o parceiro mude é a primeira das razões do por que as mulheres permanecem com seus parceiros agressores. Essa esperança advém também do fato de que o agressor não tem apenas um lado, ele pode mostrar cuidado, atenção, romance, intensidade e, de repente, mudar para o lado agressivo. Sendo que ao término da fase da lua-de-mel, as mulheres ficam frustradas quando o comportamento agressivo vem à tona novamente, é quando elas se motivam a tentar mais arduamente para que a relação dê certo.

A participação do agressor na psicoterapia pode também ser um fator que faz com que as mulheres voltem para casa, porém, os agressores, freqüentemente, utilizam a terapia como 
forma de manipular suas parceiras e não com o objetivo de aprendizado ou de mudança (LA VIOLETTE, 2000).

Para Barnett (2000), quanto mais severas são as agressões mais a mulher permanece no relacionamento. Quão maior é a gravidade, a freqüência, o grau de dor e sofrimento, mais o relacionamento dura. La Violette (2000) discorda e afirma que a tolerância da violência doméstica, a decisão pelo divórcio, depende da individualidade de cada mulher.

Gondolf (1997) investigou que 24\% das mulheres que vivem em abrigos planejam retornar para seus parceiros, sendo que 7\% encontram-se indecisas. Herbert (1991) afirma que de um grupo de 132 mulheres de uma comunidade de mulheres agredidas, 66\% deixaram seus parceiros, das que permaneceram 50\% já os deixaram no mínimo uma vez. Essas pesquisas indicam que sair do relacionamento abusivo é um processo com muitas idas e vindas, sendo, raramente, feito em um único evento. Em um estudo com 512 mulheres agredidas moradoras de um abrigo, 74,2\% separaram-se no mínimo uma vez de seus parceiros, e algumas se separaram mais de dez vezes (HERBERT, 1991). Browne (1983) afirma que para a mulher deixar um relacionamento abusivo ela deve passar por um processo com várias etapas. Conforme o autor, basicamente as etapas que ela deve superar são: 1) reconhecer que seu relacionamento é perigoso para ela; 2) convencer-se de que o parceiro não irá melhorar; 3) desistir do sonho de ter um relacionamento perfeito, idealizado; 4) aceitar que as agressões não terminarão.

De acordo com Barnett (2000), para a mulher agredida deixar o parceiro, ela deve primeiro quebrar a situação de isolamento em que normalmente se encontra, depois deve ter alguém em sua vida que a encoraje e a apóie em qualquer situação, além de convencê-la de que ela é muito importante, assim como sua vida. A autora acredita que a mulher agredida precisa de um novo espelho da realidade, e uma pessoa amiga pode segurá-lo para ela enxergar melhor. 
As mulheres entrevistadas relatam a vontade de se separar do parceiro, porém não tomam atitudes para que isso aconteça. Débora já saiu de casa uma vez e, recentemente, perdoou o marido que já a agrediu novamente. Priscila falou várias vezes ao longo da entrevista que não agüenta mais o parceiro, mas quando desligamos o gravador ela disse que vai esperar mais um tempo para ver se ele melhora. Paula fala em separação e depois comenta “se a gente for separar mesmo de uma vez [...]”. Júlia é a única que não fala em separação. E, como já dito anteriormente, Rose foi expulsa de casa e Paula saiu de casa, porém ainda não tomou nenhuma providência para que a separação aconteça conforme a lei.

Assim, os objetivos propostos pelo estudo foram alcançados com relação às percepções das mulheres sobre violência, suas justificativas e efeitos no cotidiano, sobre si própria, sobre seus parceiros e acerca de seu relacionamento. A questão do por que algumas mulheres permanecem com o parceiro agressor precisa ser mais investigada, porém, acreditamos que algumas despretensiosas hipóteses foram exploradas. 


\section{CONSIDERAÇÕES FINAIS E IMPLICAÇÕES SOCIAIS}

A banalização da violência doméstica mais as conseqüências que ela provoca na mulher como depressão, ideação suicida, inclusive, a possibilidade da ocorrência de um homicídio por parte do agressor faz-nos pensar sobre a necessidade dela ser reconhecida tão logo aconteça com alguém, para que uma intervenção possa ser feita.

Com isso, nossa maior preocupação sobre o fenômeno da violência doméstica que assola as famílias da sociedade atual é com relação as suas formas de prevenção. Divulgar o que é a violência doméstica e como proceder, caso isso aconteça, é garantir que a comunidade esteja alerta ao problema e saiba se defender em caso de necessidade.

Porém, não adianta saber onde buscar ajuda se as Instituições e os profissionais das áreas pertinentes ao problema não estiverem preparados para uma intervenção adequada e de qualidade.

Assim, os dados da presente pesquisa apontam para algumas implicações sociais:

- A sociedade precisa mudar não somente a forma de lidar com a cultura machista ainda vigente, mas também a forma como trata suas mulheres. A violência doméstica contra a mulher é parte de uma luta maior que visa a exterminar com o preconceito contra a mulher, principalmente, com a da mulher negra que é a mais atingida;

- As pessoas precisam aprender a reconhecer a violência doméstica e suas variadas manifestações, como a física, a psicológica e a sexual, para buscarem ajuda e saberem como proceder se algo lhes acontecer;

- A educação da comunidade é a peça principal de qualquer programa de prevenção. Evidências mostram que uma palestra de vinte minutos realizada em uma universidade sobre violência doméstica conseguiu provocar mudanças em algumas pessoas (BARNETT, 2000); 
- A importância de um treinamento específico para a polícia, que tem um papel central na interrupção do ciclo da violência, no momento em que atende uma chamada. Aprimorar sua intervenção em casos desse tipo e promover uma melhor compreensão com relação ao contexto psicossocial do problema pode possibilitar um atendimento de maior qualidade e precisão;

- Os trabalhadores sociais também devem receber treinamento, a fim de direcioná-los no atendimento de mulheres e crianças agredidas para que possam vê-los como clientes que precisam de proteção;

- Os treinamentos ou palestras realizados devem sensibilizar o público-alvo para as conseqüências familiares que a violência doméstica traz. Incluir uma mulher agredida e uma criança para dar testemunho no treinamento aumenta a empatia dos ouvintes com relação ao problema, segundo Wuest (1999), é uma estratégia eficiente para atingir o coração de quem escuta;

- Novas pesquisas nessa área precisam ser realizadas, principalmente, no Brasil, com o objetivo de nos esclarecer um pouco mais sobre a dificuldade da mulher agredida em deixar o parceiro agressor, para que possamos aprimorar nossas técnicas profissionais, qualquer que seja a área de atuação (psicólogos, médicos, advogados, assistentes sociais), na busca de ajudá-las da maneira mais eficiente possível;

- A inovação das psicoterapias para esse tipo de caso é de fundamental importância para que todos os aspectos da vida da mulher, oriundos da agressão ou precursores dessa, possam ser trabalhados de forma que ela possa vivenciar uma estabilidade psicológica;

- A ética deve estar presente no cotidiano de todos os profissionais que trabalham com casos de violência doméstica, independente se a pessoa for a vítima ou a agressora.

- Gostaríamos de dizer que algumas técnicas de psicoterapia referentes à auto-estima e autoconfiança com mulheres vítimas foram aplicadas pela pesquisadora no seu dia-a-dia 
de trabalho e que os resultados alcançados foram positivos. Acreditamos que no futuro, isso possa ajudar numa próxima pesquisa;

- Sugerimos que manuais de atendimento e orientação às vítimas possam ser criados no Brasil para respaldar o trabalho dos profissionais da área;

- Acreditamos que se nossa luta acontecer na direção da libertação da mulher, assim como da do homem também, pois ambos sofrem pressões para desempenharem papéis estereotipados pela sociedade, poderemos viver nossas individualidades de forma plena e, com isso, aprenderemos, com certeza, a conviver em relações de troca e reciprocidade.

Assim, acreditamos que este estudo possa provocar discussões sobre a violência doméstica contra a mulher, sobre as políticas públicas promovidas pelo governo, principalmente, no aspecto da saúde, que possam ficar questões a serem aprofundadas e que esta pesquisa possa despertar em outras pessoas o desejo de estudarem o tema e de contribuírem para essa luta social que é de todos nós. 


\section{REFERÊNCIAS BIBLIOGRÁFICAS}

ADEODATO, V. G. et al. Qualidade de vida e depressão em mulheres vítimas de seus parceiros. Rev. Saúde Pública. Fortaleza, v. 39, n. 1, 2005. Disponível em: <http://www.scielo.br>. Acesso em: 03 dez. 2006.

ALSDURF, J. M. Wife abuse and the church: the response of pastors. Response, Vol. 8, n. 1, p. 9-11, 1985.

ALMEIDA, S. S. Femicídio, algemas (In)visíveis do público/privado. Rio de Janeiro: Revinter, 1998. p. 176.

; PITANGUY, J. O que é feminismo. São Paulo: Brasiliense, 1981. p. 78.

ALVES, F. M. Lei Maria da Penha: das discussões à aprovação de uma proposta concreta de combate à violência doméstica e familiar contra a mulher. Jus Navigandi, Teresina, ano 10, n. 1133, 8 ago. 2006. Disponível em: <http://jus2.uol.com.br/doutrina/texto.asp?id=8764>. Acesso em: 09 maio 2007.

ANDERSON, K. L. Gender, status and domestic violence: An integration of feminist and family violence approaches. Jounal of Marriege and the Family, Vol. 59, p. 655-669, 1997.

ARANHA, M. L. A. História da Educação. São Paulo: Moderna, 1989. p. 288.

ARAÚJO, E. A arte da sedução: sexualidade feminina na Colônia. In: DEL PRIORE, M. (Org.). História das Mulheres no Brasil. São Paulo: Contexto, 2000. p. 45-77.

ARENDT, H. Da violência. In: . Crises da República. São Paulo: Perspectiva, 1973.

AZEVEDO, M.A. Mulheres espancadas: a violência denunciada. São Paulo: Cortez, 1985. p 176.

.; GUERRA, V. N. A. Vitimação e vitimização: questões conceituais. In:

GUERRA, V. N. A.; OLIVEIRA, A. B. (Org.). Crianças vitimizadas: a síndrome do pequeno poder. 2 ed. São Paulo: Iglu, 2000. p. 25-48

BALlONE, G. J. Violência doméstica. Disponível em: <http://www.psiqweb.med.br /infantil/violdome.html>. Acesso em: 14 out. 2007. 
BARDIN, L. Análise de Conteúdo. Lisboa, PT: Edições 70, 1997.

BARNETT, O. W. Gender differences in attributions of self-defense and control in interpartner aggression. Violence Against Women, California, Oct. 1997, Vol. 3, n. 5, p.462481.

It could happen to anyone: why battered women stay. California, USA: Sage Publications, 2000.

BASSANEZI, C. Mulheres dos Anos Dourados. In: DEL PRIORE, M. (Org.). História das mulheres no Brasil. São Paulo: Contexto, 2000. p. 607-639.

BENNETT, L. W. Domestic abuse by male alcohol and drug addicts. Violence and victms, Vol. 9, p. 359-368, 1994

BETTO, F. Marcas de batom. Disponível em: <http://www.carosamigos.terra.com.br>. Acesso em: 14 abr. 2007.

BEWLEY, S.; MEZEY, G. C. Domestic Violence and Pregnancy. British Medical Journal, London, v. 314, p. 1295, 1997.

BIRKE, L. Feminism and the Biological Body. London, UK: Wheatsheaf Books, 1986. p. 204.

BOGDAN, R; BIKLEN, S. Investigação Qualitativa em Educação. Porto, PT: Porto, 1997. p. 336.

BORIN, T. B; KODATO, S. Representações Sociais do feminino em dispositivo grupal de mulheres vitimizadas. In: Anais de Resumos do II Encontro da Spagesp - II Encontro de Saúde Mental da Região de Ribeirão Preto - VIII Jornada do Nesme, Spagesp, Ribeirão Preto, 2004, 55 p.

BOURDIEU, P. A dominação masculina. Rio de Janeiro: Bertrand, 1995. p. 160.

BRANDÃO, E. R. Violência Conjugal e o Recurso Feminino à Polícia. In: BRUSCHINI, C.; HOLLANDA, H. B. Horizontes Plurais: Novos Estudos de Gênero no Brasil. São Paulo: 34, 1996, p. 53-84. 
BRASIL. IBGE. 8 de março: dia internacional da mulher. Disponível em: <http://www.ibge.gov.br>. Acesso em: 15 out. 2006.

BROOKOFF, D. Drugs, alcohol, and domestic violence in Memphis. Violence Against Women, California, Nov. 1999, Vol. 5, n. 6, p.437-462.

BROWNE, A. Self-defensive homicides by battered women: relationships at risk. Violence Against Women, California, Jul. 1983, Vol. 3, n. 5, p.315-360.

BUCKLEY, S. Europe: Domestic violence - an all to common reality. Violence Against Women, California, 2000, Vol. 2, p. 365-81.

CABETTE, Eduardo Luiz Santos. Violência doméstica e familiar contra a mulher: a questão dos crimes culposos. Jus Navigandi, Teresina, ano 10, n. 1169, 13 set. 2006. Disponível em: $<$ http://jus2.uol.com.br/doutrina/texto.asp?id=8909>. Acesso em: 09 jun. 2006.

CABRAL, M. A. P. et al. Representações da violência conjugal de 117 mulheres de Campinas, Brasil. J. Bras. Psiquiatr., v. 49, p. 49-277, 2000.

CAMPBELL, J. C. A test of to explanatory models of women's responses to battering. Nursing Research, Oct. 1989, Vol. 38, n. 1, p. 18-24.

CAPLAN, P. (Org.). The cultural construction of sexuality. London, UK; New York, EUA: Routledge, 1987. p. 320.

CARDOSO, N. M. B. Psicologia e relações de gênero: a socialização do gênero feminino e suas implicações na violência conjugal em relação às mulheres. In: ZANELLA, A. V. et al. Psicologia e práticas sociais. Porto Alegre, RS: ABRAPSOSUL, 1997. p. 280-292.

CASIQUE, L. C.; FUREGATO, A. R. F. Violência contra mulheres: reflexões teóricas. Rev. Latino-Am. Enfermagem. Ribeirão Preto, v. 14, n. 6, 2006. Disponível em: $<$ http://www.scielo.br>. Acesso em: 03 mar. 2006.

CASTRO, M. G. O conceito de gênero e as análises sobre mulher e trabalho. Cadernos do CRH, Salvador, 1992, n. 17, p. 80-105.

CAVALCANTI, L. F.; ZUCCO, L. P.; SILVA, M. M. V. A.. A extensão universitária na prevenção da violência sexual. Disponível em: <http://www.ccs.uel.br>. Acesso em: 03 jan. 2005. 
CHAUÍ, M. Participando do debate sobre mulher e violência. In: FRANCHETTO, B.; CAVAlCANTI, M. L.V. C.; HEILBORN, M. L. (Orgs.). Perspectivas antropológicas da mulher. Rio de Janeiro: Zahar, 1984, v. 4, p. 25-62.

CHODOROW, N. Estrutura Familiar e personalidade feminina. In: DENICH, B.; ROSALDO, M. Z.; LAMPHERE, L. (Coord.). A mulher, a cultura e a sociedade. Tradução Cila Ankier e Rachel Gorenstein. Rio de Janeiro: Paz e Terra, 1979. p. 65-94.

COLEMAN, D. H.; STRAUS, M. A. Marital power, conflict, and violence in a nationally representative sample of American couples. Violence and Victms, Vol. 1, p. 141-147, 1986.

COLlEMAN, A. Family Violence in Canada: a Statistical Profile. Violence Against Women, California, Vol 5, 1999, p.198-227.

CONFEDERAÇÃO NACIONAL DOS TRABALHADORES EM ESTABELECIMENTOS DE ENSINO. Violência contra a mulher: a lei Maria da Penha já está em vigor. Disponível em: <http://www.contee.org.br>. Acesso em: 01 fev. 2007.

DAY, V. P. et al. Violência Doméstica e suas diferentes manifestações. Rev. psiquiatr. Rio Gd. Sul, Porto Alegre, v. 25, suppl. 1, 2003. Disponível em: <http://www.scielo.br>. Acesso em: 09 maio 2007.

DEL PRIORE, M (Org.). História das mulheres no Brasil. São Paulo: Contexto, 2004. p. 444.

DENICH, B.; ROSALDO, M. Z.; LAMPHERE, L. (Coord.). A mulher, a cultura, a sociedade. Tradução Cila Ankier e Rachel Gorenstein. Rio de Janeiro: Paz e Terra, 1979.

DESLANDES S. F. O atendimento às vítimas de violência na emergência: "prevenção numa hora dessas?”. Ciênc. saúde coletiva., Rio de Janeiro, v. 4, n. 1, 1999. Disponível em: <http://www.scielo.br>. Acesso em: 09 maio 2007.

D’íNCAO, M. A. Mulher e família burguesa. In: DEL PRIORE, M. (Org.). História das mulheres no Brasil. São Paulo: Contexto, 2000. p. 223-240.

DINIZ, S. G. Violência contra a mulher: estratégias e respostas do movimento feminista no Brasil (1980-2005). Disponível em: <http://www.mulheres.org.br>. Acesso em: 24 maio 2007. 
EAGLETON, T. Teoria da Literatura: uma introdução. São Paulo: Martins Fontes, 1983. p. 348.

FALCONNET, G. E.; LEFAUCHEUR, N. A fabricação dos machos. Rio de Janeiro: Zahar, 1977. p. 214.

FERREIRA, A. B; CUSTÓDIO, T. V. O. A construção do feminino na visão de Gilberto Freire. Rev. Ciências Sociais. João Pessoa, n. 2, 2000. Disponível em: <http://www.cchla.ulpb.br>. Disponível em: 11 nov. 2006.

FIGUEIRA, S. A. (Org.) Uma nova família? O moderno e o arcaico na família de classe média brasileira. Rio de Janeiro: Zahar, 1987. p. 112.

FURNISS, T. Abuso Sexual da Criança. Porto Alegre: Artes Médicas, 1993.

GABEL, M. Crianças Vítimas de Abuso Sexual. São Paulo: Summus, 1997.

GIFFIN, K. Violência de gênero, sexualidade e saúde. Cad. Saúde Pública, Rio de Janeiro, v. 10, suppl. 1, 1994. Disponível em: <http://www.scielo.br>. Acesso em: 09 maio 2007.

GONDOLF, E. W. Spousal homicide in Russia. Gender inquality in a multifactor model. Violence Against Women, California, Vol 3, 1997, p. 533-46.

Battered women as survivors: An alternative to treating learned helplessness.

Journal of Interpersonal Violence, Vol 3, 1999, p. 275-289.

GUIMARÃES, G. F. et al. Homens apenados e mulheres presas: estudo sobre mulheres de presos. Psicol. Soc., Porto Alegre, v. 18, n. 3, 2006. Disponível em: <http://www.scielo.br>. Acesso em: 09 maio 2007.

HABERMAS, J. O conceito de poder de Hannah Arendt. In: FREITAG, B.; ROUANET, S. P. (Orgs.). Habermas. São Paulo: Ática, 1980. p.100-118.

HALL, D.; LINCH, M. A. Violence begin at home. British Medical Journal, London, Vol. 316, p. 1551-1560, 1998.

HAMBERGER, L. K. An empirical classification of motivations for domestic violence. Violence Against Women, California, Aug, 1997, Vol. 3, n. 4, p.401-23. 
HEISE, L.; PITANGUY, J.; GERMAIN, A. Violence against women. The hidden health burden. Washignton, DC: World Bank; 1994. p. 255.

; ELLSBERG. M; GOTTEMOELLER, M.. Ending Violence against Women. Baltimore, USA: Population Reports, 1999.

HEBBERT, .T. B. Coping with an abusive relationship: How and why do women stay? Journal of Marriage and the Family, 1991, Vol. 53, p. 311-325.

INSTITUTO PATRÍCIA GALVÃO. Tipos de violência. Disponível em: <http://www.patriciagalvao.org.br>. Acesso em: 03 jan. 2007.

IPAS. Ipas e a violência contra a mulher. Disponível em: <http://www.ipas.org.br>. Acesso em: 21 fev. 2007.

JACKSON, M. 'Facts of life' or the eroticization of women's oppression? Sexology and the social construction of heterosexuality. In: CAPLAN, P. (Org.). The cultural construction of sexuality. London, UK; New York, EUA: Routledge, 1987. p. 52-81.

JAIME, S. Violência doméstica: a prevenção como caminho. Jus Navigandi, Teresina, ano 10, n. 1182, 26 set. 2006. Disponível em: <http://jus2.uol.com.br/doutrina/ texto.asp?id=8972>. Acesso em: 22 out. 2007.

JOHNSON, M. P; FERRARO, K. J. Research on domestic Violence in the 1990s: Making Distinctions. Transactions of the Institute of British Geographers, London, Vol 26, 2001, p.365.

KAUKINEN, C. Status Compatibility, Physical Violence, and Emotional Abuse in Intimate Relationships. Journal of Marriage and Family, London, Vol 66, 2004, p.452

KIRK, R. Untold terror: Violence against women in Peru's armed conflict. Journal of Marriage and Family, London, Vol 53, 1999, p. 63-82.

KRONBAUER, J. F. D.; MENEGUEL, S. N. Perfil da violência de gênero perpetrada por companheiro. Rev. Saúde Pública. São Paulo, v. 39, n. 5, 2005. Disponível em: <http://www.scielo.br>. Acesso em: 03 mar. 2006. 
LAURENTIS, T. A tecnologia do gênero. In: HOLLANDA, H. B. (Org.). Tendências e impasses: o feminismo como crítica da modernidade. Rio de Janeiro: Rocco, 1994. p. 206242.

LA VIOLETTE, A. L. Battered women, power, and family systems therapy. Garden Grove, CA: Newman, 2000.

LOURO, G. L. Nas redes do conceito de gênero. In: LOPES, M. J. M.; MEYER, D. E.; WALDOW, V. R. (Orgs.). Gênero e saúde. Porto Alegre, RS: Artes Médicas, 1996. p. 7-18.

MACEDO, J. R. A mulher na Idade Média. São Paulo: Contexto, 1990. p. 95.

MACHADO, O. M. Mulher: códigos legais e códigos sociais - papéis dos direitos e os direitos de papel. Disponível em: <http://www.oab.org.br>. Acesso em: 03 jan. 2007.

MARINHEIRO, A. L. V. Violência doméstica: prevalência entre mulheres usuárias de um serviço de saúde de Ribeirão Preto - SP. 2003. 136 f. Dissertação (Mestrado em Medicina). Faculdade de Medicina de Ribeirão Preto, Universidade de Ribeirão Preto, São Paulo, 2003.

MAZONI, L. S. A questão do imaginário no atendimento a mulheres em situação de violência. Disponível em: <http://www.mulheres.org.br >. Acesso em: 27 mar. 2007.

MILLER, P; COHEN, E. A. Why don't battered women just take their children and leave? American Psychological Association, United States, Vol 2, 2004, p.41-62.

MINAYO, M. C. S. O desafio do conhecimento: Pesquisa Qualitativa em Saúde. 2 ed. São Paulo; Rio de Janeiro: Hucitec-Abrasco, 1993.

MRSEVIC, Z.; HUGHES, D. M. Violence against women in Belgrade, Serbia: SOS hotline 1990-1993. Violence against women, Vol. 3, p. 101-128, 1997.

MULLEN, P. et al. Impact of sexual and physical abuse on women's mental health. Lancet, Vol. 1, p. 841-845, 1998.

MURARO, R. M. Libertação Sexual da Mulher. Petrópolis: Vozes, 1975. p. 166. Breve introdução histórica. In: KRAMER, N.; SPRENGER, J. O martelo das feiticeiras. 9. ed. Rio de Janeiro: Rosa dos Tempos, 1993. 
NAÇÕES UNIDAS. Disponível em: <http://www.onu-brasil.org.br>. Acesso em: 2 abr. 2004.

NEVES, A. S. A violência física de pais e mães contra filhos: cenário, história e subjetividade. 2004. 26 f. Dissertação (Doutorado em Psicologia). Faculdade de Filosofia Ciências e Letras de Ribeirão Preto, Universidade de Ribeirão Preto, São Paulo, 2004.

NOBLECOURT, C. D. A mulher no tempo dos faraós. Tradução Tânia Pellegrini. Campinas, SP: Papirus, 1994. p. 416.

NÚCLEO DE OPINIÃO PÚBLICA DA FUNDAÇÃO PERSEU ABRAMO. Disponível em: $<$ http://www.fpa.org.br/nop>. Acesso em: 22 abr. 2004.

8 de março - mulheres fazendo história. Disponível em: <http://www.portal.prefeitura.sp. gov.br>. Acesso em: 21 jan. 2007.

O’NEIL, J.M. A multivariate model explaining men's violence toward women. Predisposing and triggering hypotheses. Violence Against Women, California, Vol 3, 1997, p. 182-203.

OLIVEIRA, E. Fórum: violência sexual e saúde. Introdução. Cad. Saúde Pública. Rio de Janeiro, v. 23, n. 2, 2007. Disponível em: <http://www.scielo.br>. Acesso em: 03 jan. 2007.

OLIVEIRA, R. D.; BARSTED, L. L.; PAIVA, M. A violência doméstica. Rio de Janeiro: Marco Zero, 1984. p. 81.

PATTI, E. M. R. O que pode uma mulher? Sexualidade, Educação e Trabalho. Franca, SP: Unesp, 2004. p. 90.

PAVEZ, G. A. Expressões da violência: violência doméstica. Disponível em: <http://www.mulheres.org.br >. Acesso em: 27 mar. 2007.

PEDRO, W. J. A. Metamorfoses masculinas: significados objetivos e subjetivos. Uma reflexão psicossocial na perspectiva da identidade humana. 2002, 240 f. Dissertação (Doutorado em Psicologia) - Pontifícia Universidade Católica de São Paulo, São Paulo, 2002.

PINHEIRO, P. S. A criança e o adolescente: compromisso social. In: AZEVEDO, M. A.; GUERRA, V. N. A.; OLIVEIRA, A. B. Crianças vitimizadas: a síndrome do pequeno poder. 2 ed. São Paulo: Iglu, 2000. p. 9-11 
PINTO, C. R. J. Uma história do feminismo no Brasil. São Paulo: Perseu Abramo, 2003. p. 119.

PRADO, D.; OLIVEIRA, C. F. Relacionamento entre homens e mulheres nas camadas de baixa renda: amor e violência Jornal brasileiro de psiquiatria, Rio de Janeiro, 1982, v. 31, p. 6-10.

RAGO, M. Epistemologia feminista, gênero e história. Disponível em: <http://www.mulheres.org.br >. Acesso em: 27 mar. 2007a.

Gênero e violência: uma abordagem histórica. Disponível em:

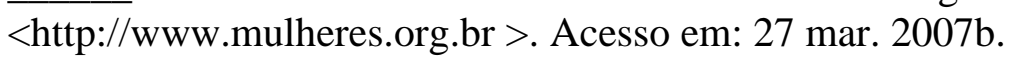

RAMINELLI, R. Eva Tupinambá. In: DEL PRIORE, M (Org.). História das mulheres no Brasil. 3 ed. São Paulo, Contexto, 2000. p. 11-44.

RECHTMAN, M.; PHEBO, L. Pequena história da subordinação da mulher: as raízes da violência de gênero. Disponível em: <http://www.isis.cl>. Acesso em: 29 set. 2006.

RICHARDSON, J.; FEDER, G. Domestic violence against women. British Medical Journal, London, Vol. 311, n. 7011, p. 964-965, 1995.

ROCHEFORT, C. O mito da frigidez feminina. In: DURAN, E. (Org.). Liberação da mulher. Belo Horizonte, MG: Ano zero; Interlivros, 1978. p. 45-60.

ROMANELLI, G. Autoridade e poder na família. In: CARVALHO, M. C. B. (Org.). A família contemporânea em debate. São Paulo: EDUC/Cortez, 1997. p. 73-88.

ROQUE, E. M. S. T.; FERRIANI M. G. C. Desvendando a violência doméstica contra crianças e adolescentes sob a ótica dos Operadores do Direito na Comarca de Jardinópolis-SP. Rev. Latino-Am. Enfermagem., Ribeirão Preto, v. 10, n. 3, 2002. Disponível em: $<$ http://www.scielo.br>. Acesso em: 09 maio 2007.

ROSALDO, M. Z. A mulher, a cultura e a sociedade: uma revisão. In: DENICH, B.; LAMPHERE, L (Coord.). A mulher, a cultura e a sociedade. Tradução Cila Ankier e Rachel Gorenstein. Rio de Janeiro: Paz e Terra, 1979. p. 33-65

RUSSEL, M. N. Psychological profiles of violent and nonviolent martially distressed couples. Psychoterapy, 1989, Vol. 23, p. 81-87.. 
SAFFIOTI, H. I. B. A mulher na sociedade de classes: mito e realidade. Petrópolis: Vozes, 1998. p. 383.

. O poder do macho. 4 ed. São Paulo: Moderna, 1987. p. 120.

; ALMEIDA, S. S. Violência de gênero: poder e impotência. Rio de Janeiro: Revinter, 1995. p. 218.

; MUÑOZ-VARGAS, M. (Org.). Mulher brasileira é assim. Rio de Janeiro: Fundo das Nações Unidas para a Infância: Rosa dos Tempos, 1994. p. 288.

SAGIM, M. B. Estudo sobre relatos de violência contra a mulher segundo denúncias registradas em delegacia especializada na cidade Goiânia - Goiás nos anos de 1999 e 2000. 2004, 117 f. Dissertação (Mestrado em Psicologia) - Faculdade de Filosofia Ciências e Letras de Ribeirão Preto, Universidade de São Paulo, São Paulo, 2004.

SALBER, P. R; TALIAFERRO, E. The physician's guide to domestic violence - How to ask the right questions and recognize abuse. California, EUA: Volcano Press, 1994. p. 117.

SANTOS, P. V. A mulher e a instituição do casamento no Egito Antigo: da liberdade às restrições morais. Disponível em: <http://www.anpuh.org>. Acesso em: 11 nov. 2006.

SAPORETI, E. A mulher como signo em crise. 1985, 292 f. Dissertação (Mestrado) Pontifícia Universidade Católica de São Paulo, São Paulo, 1985.

SCHRAIBER, L. B.; D’OLIVEIRA, A. F. L. P. Violência contra mulheres: interfaces com a saúde. Disponível em: <http://www.interface.org.br>. Acesso em: 10 abr. 2007.

SCOTT, J. Gênero: uma categoria útil para a análise histórica. Tradução Christiane Rufino Dabot e Maria Bethânia Ávila. Recife, PE: S.O.S Corpo, 1989.

SEIDLER, V. J. Reason, desire, and male sexuality. In: CAPLAN, P. (Org.). The cultural construction of sexuality. London, UK; New York, EUA: Routledge, 1987, p. 82-112.

SHEPARD, M. Twenty years of progress in addresing domestic violence: an agenda for the next 10. Journal Interpers Violence. Vol 4, 2005, p.436-41. 
SILVA, M. V. Violência contra a mulher: quem mete a colher? São Paulo: Cortez, 1992. p. 180.

SMITH, M. D. Patriarchal ideology and wife beating: A test of a feminist hypothesis. Violence and Victims, 1990, Vol. 5, p. 257-273.

SOARES, B. M. Mulheres invisíveis: violência conjugal e novas políticas de segurança. Rio de Janeiro: Civilização Brasileira, 1999. p. 320.

SOUZA, C. M.; ADESSE, L. Violência sexual no Brasil: perspectivas e desafios. Disponível em: <http://www.ipas.org.br>. Acesso em: 14 mar. 2007. 1999. p. 296.

Práticas discursivas e produção de sentidos no cotidiano. São Paulo: Cortez,

STARK, E., FLITCRAFT, A. Spouse abuse. In: ROSEMBERG, M. L.; FENLEY, M. A. (ed.). Violence in America: A Public Health approach. New York, EUA: Oxford University Press, 1991. p. 123-157.

STOVER, C.S. Domestic violence research: what have we learned and where do we go from here? Journal Interpers Violence. Vol 4, 2005, p. 448-454.

SUGG, N. K. et al. Domestic violence and primary care: attidudes, practices and beliefs. Arch. Fam. Med., v.8, p.301-306, 1999.

TAVARES, D. M. C. Violência no Brasil. Disponível em: <http://www.prefeitura.sp.gov.br/ especialmulher/especialmulher violencia.htm>. Acesso em: 14 maio 2004.

TELES, M. A. A. Breve História do Feminismo no Brasil. São Paulo: Brasiliense, 1993. p. 181.

120.

; MELO, M. O que é violência contra a mulher. São Paulo: Brasiliense, 2002. p.

TURATO, E. R. Tratado de Metodologia da Pesquisa Clínico-Qualitativa: Construção teórico - epistemológica - discussão comparada e aplicação nas áreas da saúde e humanas. 2 ed. Petrópolis: Vozes, 2003. p. 688. 
VERARDO, T. Violência. Disponível em: <http://www.mulheres.org.br>. Acesso em: 27 mar. 2007a.

. Do amor ao ódio. Disponível em: <http://www.mulheres.org.br>. Acesso em: 27 mar. 2007b.

VERRUCCI, F. Minha cara Maria Amélia. In: AZEVEDO, M. A. Mulheres espancadas: a violência denunciada. São Paulo: Cortez, 1985.

VIEZZER, M. O problema não está na mulher. São Paulo: Cortez, 1989.

WALKER, L. E. The battered women. Violence Against Women, 1979, Vol. 1, n. 1, p. 3245.

WARRINGTON, M. "I must get out": the geographies of domestic violence. Acta Psychiatrica Scandinavica, Vol 106, 2002, p.15.

WUEST, J. Not going back: Sustaining the separation in the processe of leaving abuse relationships. Violence Against Women, California, 1999, Vol. 5, p. 110-133.

ZAIDMAN, L. B. As filhas de Pandora - mulheres e rituais nas cidades. In: DUBY, G.; PERROT, M. (Org.). História das mulheres no Ocidente: a Antiguidade. Porto Alegre: Afrontamento, 1990.

ZORDAN, P. B. M. B. G. Bruxas: figuras de poder. Rev. Estud. Fem., Florianópolis, v. 13, n. 2, 2005. Disponível em: <http://www.scielo.br>. Acesso em: 09 maio 2007. 


\section{ANEXOS}

ANEXO A - Carta de aprovação do Comitê de Ética de Pesquisa - USP

UNIVERSIDADE DE SÃO PAULO

FACULDADE DE FILOSOFIA, CIÊNCIAS E LETRAS DE RIBEIRÄO PRETO

COMITE DE ÉTICA EM PESQUISA - CEP

Of.CEtP/031/2005-19.05.2005

Senhor(a) Pesquisador(a):

Comunicamos a V. Sa. que o trabalho intitulado "VIOLENCIA DE GÊNERO: REPRESENTAÇÕES SOCIAIS DE PODER EM MULHERES VÍTIMAS" foi analisado pelo Comitê de Ética em Pesquisa da FFCLRP-USP, em sua 42a Reunião Ordinária realizada em 19/05/2005, e enquadrado na categoria: APROVADO, de acordo com o Processo CEPFFCLRP $n^{\circ}$ 188/2005 - 2005.1.638.59.1

Aproveitamos a oportunidade para apresentar nossos protestos de estima e consideração.

Atenciosamente,

Profa. Dra. Eucla Beatriz Lopes Petean Coordenadora do Comitê de Ética em Pesquisa - FFCLRP-USP

llustríssimo(a) Senhor(a)

THAISA BELLOUBE BORIN

Aluna(o) do Programa de PG em Psicologia

C.C. PROF. SÉRGIO KODATO

CEP-FFCLRP-USP - Fone: (016) 602-3653 - Fax: (016) 633-5015 Avenida Bandeirantes, 3900 - Bloco A - 14040-901 - Ribeirão Preto - SP - Brasil 


\section{ANEXO B - Termo de Consentimento Livre e Esclarecido}

(De acordo com a Resolução $n^{0}$ 196/96 sobre Pesquisa Envolvendo Seres Humanos do Conselho Nacional de Saúde - Ministério da Saúde - Brasília-DF)

Meu nome é Thaisa Belloube Borin, sou psicóloga e aluna do mestrado da Faculdade de Filosofia Ciências e Letras de Ribeirão Preto da Universidade de São Paulo. Estou realizando uma pesquisa intitulada "Violência de gênero: Representações Sociais de poder em mulheres vítimas” e sou supervisionada pelo Prof. Dr. Sérgio Kodato.

O meu objetivo nesta pesquisa é conhecer quais são as percepções das mulheres agredidas sobre gênero e de que forma isso contribui para que elas permaneçam ou não com o parceiro agressor. E gostaria de convidá-la para participar deste estudo.

Esta pesquisa é importante para conhecer melhor as vivências de pessoas como você, e podermos contribuir com o trabalho dos profissionais de saúde. Através desse novo conhecimento possibilitado pela pesquisa, os profissionais poderão aprimorar as orientações e os tratamentos oferecidos às mulheres que sofrem agressões.

A sua participação será responder a uma entrevista, na qual falaremos sobre sua história de vida, mas, principalmente, sobre a violência que sofre e já sofreu por parceiros e/ou familiares. Em função de você estar sendo atendida na Delegacia da Mulher, as entrevistas serão realizadas neste local. As entrevistas serão feitas em um único encontro e eu gostaria de gravá-las, caso permita. As gravações são importantes para que eu possa ter suas respostas preservadas do modo como foram ditas e, posteriormente, transcrevê-las e analisá-las.

Durante a entrevista, estaremos falando de um assunto íntimo, que pode trazer lembranças e sentimentos à tona. Caso não se sinta à vontade para continuar a entrevista, você tem o direito de interrompê-la a qualquer momento. 
Após a realização da transcrição do seu relato, você terá a possibilidade de ler o que foi dito na entrevista. Desta forma, você poderá (caso desejar) modificar algo no relato ou até mesmo desistir de participar desta pesquisa.

É muito importante esclarecer que sua identidade (seu nome) não será revelada em nenhum momento. Eu utilizarei os relatos na pesquisa, publicarei e arquivarei os depoimentos, tomando os cuidados para que você e as pessoas que venham a ser citadas não sejam identificadas neste trabalho. Só eu conhecerei sua identidade e me prontifico a guardar sigilo sobre a mesma.

Para que eu possa realizar esta pesquisa, preciso que assine esse documento que deixa claro a sua decisão livre e espontânea em aceitar ser entrevistada, após ter lido o que foi dito acima e ter sanado quaisquer dúvidas que tenham surgido sobre a sua participação neste estudo.

Após assinar esse documento, você continua tendo o direito de interromper a entrevista ou não responder a alguma pergunta, sem precisar explicar seus motivos para a recusa. Essa desistência não a prejudicará de forma alguma.

Este termo será assinado por mim e pela entrevistada, sendo que uma das duas cópias ficará comigo, e outra com você. 


\section{ANEXO C - Certificado de Consentimento}

Eu (nome do entrevistado) R.G. $\mathrm{n}^{\mathrm{o}}$ declaro estar informada sobre a minha participação na pesquisa intitulada "Violência de gênero: Representações Sociais de poder em mulheres vítimas”. Após ter as minhas dúvidas esclarecidas pela pesquisadora, declaro que concordo em participar deste estudo, sob a responsabilidade da psicóloga Thaisa Belloube Borin. Minha participação é livre e espontânea, conforme o que foi exposto no termo de consentimento. Após dar meu relato, terei a possibilidade de ler a transcrição do mesmo e poderei interromper minha participação neste trabalho, caso sinta necessidade. Eu permito a divulgação dos dados desta pesquisa, estando ciente de que eles não serão associados a mim e às pessoas que eu possa me referir.

1. ( ) Autorizo a gravação do meu depoimento.

2. ( ) Aceito a realização de uma segunda entrevista, caso a pesquisadora necessite esclarecer possíveis dúvidas.

Ribeirão Preto, , de , de 2005.

Assinatura do entrevistado:

Assinatura da pesquisadora:

Thaisa Belloube Borin

CRP - 06/69065 


\section{ANEXO D - Roteiro da entrevista}

1) Conte-me sobre o que aconteceu que você decidiu vir até a Delegacia de Defesa da Mulher?

2) Por que tomou essa iniciativa de prestar queixa nesse momento da sua vida, e não o fez antes?

3) Quais são suas expectativas com relação ao Boletim de Ocorrência?

4) Fale-me um pouco da sua família.

5) Fale-me um pouco das agressões que sofreu ou cometeu ao longo da vida.

6) Como você se sente com relação ao atual agressor?

7) Fale-me um pouco dos homens que passaram por sua vida?

8) Como você se sente com relação à agressão sofrida?

9) Quais são seus planos para o futuro? 


\title{
ANEXO E - Crimes de competência da DDM
}

\section{Título I - Capítulo I}

\author{
Artigo 121 Homicídio \\ Artigo 122 Induzimento, investigação ou auxílio a suicídio \\ Artigo 123 Infanticídio \\ Artigo 124 Aborto provocado pela gestante ou com seu consentimento \\ Artigo 125 Aborto provocado por terceiro \\ Artigo 126 Provocar aborto sem consentimento da gestante
}

\section{Título I - Capítulo II}

Artigo 129 Lesão Corporal

\section{Título II - Capítulo III}

Artigo 130 Perigo de contágio venéreo

Artigo 131 Perigo de contágio de moléstia grave

Artigo 132 Perigo de vida ou saúde de outrem

Artigo 133 Abandono de incapaz

Artigo 134 Exposição ou abandono de recém-nascido

Artigo 135 Omissão de socorro

Artigo 136 Maus-tratos

\section{Título I - Capítulo V}

Artigo 138 Calúnia

Artigo 139 Difamação

Artigo 140 Injúria 


\section{Capítulo VI - Seções I e II}

Artigo 146 Constrangimento Ilegal

Artigo 147 Ameaça

Artigo 148 Seqüestro e cárcere privado

Artigo 149 Redução a condição análoga à de escravo

Artigo 150 Violação de domicílio

\section{Título II}

Artigo 163 Dano

Artigo 173 Abuso de incapazes

\section{Título VI}

Artigo 213 Estupro

Artigo 214 Atentado violento ao pudor

Artigo 215 Posse sexual mediante fraude

Artigo 216 Atentado ao pudor mediante fraude

Artigo 216 a) Assédio Sexual

Artigo 217 Sedução

Artigo 218 Corrupção de Menores

Artigo 219 Rapto violento ou mediante fraude

Artigo 220 Rapto consensual

Artigo 227 Mediação para servir a lascívia de outrem

Artigo 228 Favorecimento da prostituição

Artigo 229 Casa da prostituição

Artigo 230 Rufianismo 
Artigo 231 Tráfico de mulheres

Artigo 233 Ato obsceno

Artigo 234 Escrito ou objeto obsceno

\section{Título VII}

Artigo 235 Bigamia

Artigo 236 Induzimento a erro essencial e ocultação de impedimento

Artigo 237 Conhecimento prévio de impedimento

Artigo 238 Simulação de autoridade para celebração de casamento

Artigo 239 Simulação de casamento

Artigo 240 Adultério

Artigo 241 Registro de nascimento inexistente

Artigo 242 Parto suposto. Supressão ou alteração de direito inerente ao estado

Artigo 243 Sonegação de estado de filiação

Artigo 244 Abandono Material

Artigo 245 Entrega de filho menor a pessoa inidônea

Artigo 246 Abandono Intelectual

Artigo 248 Induzimento a fuga, entrega arbitrária ou sonegação de incapazes

Artigo 249 Subtração de incapazes

\section{Título X}

Artigo 305 Supressão de Documento 